\title{
WINDĖSISCHE VERHALEN
}

\author{
met vertaling en woordenlijst
}

DOOR J. A. VAN BALEN.

\section{EEN WOORD VOORAF.}

De taal dezer "amissi» (si is de meervoudsvorm) noemde ik de Windèsische. I $\mathrm{k}$ deed dat in navolging van hen onder wie ik als zendeling 23 jaar leefde, en van wie ik deze amissi opteekende.

Het spraakgebied dezer taal is langs de kust der Geelvincksbaai van af Sjari tot aan de punt der landtong die de Wandàmenbaai vormt, op en over de landengte tusschen de Geelvincksbaai en de Mac-Cluergolf benevens een deel der oostelijke kusten dier golf, benevens de Mooreilanden in de oostelijke helft der Geelvinksbaai, in welke helft het langs de kust door velen verstaan en gesproken wordt. Uit een dezer amissi blijkt dat ook de Ansoesers in de onmiddellijke nabijheid van Windèsi hebben gewoond, wat tot heden mede nog uit hun taal moet blijken. $\mathrm{Bij}$ de Wandàmers vindt men eenige afwijkingen. Zoo wordt bijv. inplaats van de $\mathrm{S}$ aan het begin van een lettergreep een $\mathrm{H}$ gevonden: masoi-mahoi.

Aanleiding tot het verzamelen dezer amissi was de toezending van een overdruk uit de Bijdragen tot de Taal, Land, en Volkenkunde van Ned. Indië: "Noefoorsche fabelen en vertellingen " door den schrijver, mijn vriend en medezendeling F. J. F. van Hasselt. Dat de taal-wetenschap zooveel belang stelt in dergelijke verhalen dat ze gedrukt worden, had ik tot dien tijd, niet geweten.

Het woord «amis» meen ik het best te vertalen met legende. Toen mijne Vrouw op de school eens een Bijbelsch verhaal amis noemde, zeiden de grootste scholieren: dat is geen amis, maar een tatòpan (Noefoorsch: kakòfen). Een amis is wat Tuan nu vraagt en opschrijft; die vertellen we zoo maar, maar gelooven we niet.»

Dl. 70 
Een raadsel noemt de Windèsiër: pi kambioi. Pi is een ding, iets, en kambioisi is een soort groente, lancet vormige bladen, die ongeveer 8 centimeter lang worden, in de eerste ontwikkeling bruinachtig-groen zijn, en slap neer hangen, doch bij het rijp worden zich oprichten en een frisch-groene kleur aannemen. Het vinden van overeenkomst van een raadsel met zulke bladen is wel eigenaardig.

Bezwaren om deze amissi los te krijgen heb ik niet ondervonden. I $\mathrm{k}$ geloof dit te mogen toeschrijven aan het door ons gewonnen vertrouwen, en de toenadering der Papoea's tot het Christendom, dat in de laatste jaren zich openbaarde. Zoodra ik vernomen had van wien ik een amis zou kunnen hooren, was de verteller of vertelster steeds bereid die mee te deelen, en dat op elk uur van den dag waarop ik dat verlangde. Van amissi die alleen in 't duister mochten worden gehoord vernam ik niets. Ook niets van absoluut persoonlijk eigendom er van. Waar een amis betrekking had op de adat van een der acht Windèsische geslachten, moest ik deze natuurlijk vernemen van een der oudste van zulk een geslacht. Het gebeurde echter wel dat zoo een verhaler aan 't eind van zijn oogenblikkelijk kunnen was, en mij dan vroeg met het verder vertellen te mogen wachten tot hij bij anderen zijn geheugen eerst wat opgefrischt had. Van belooning voor het vertellen was nooit sprake. Onder het rooken van een aangeboden sigarette zat men kalm te vertellen en te herhalen, en alle gevraagde inlichtingen te verschaffen. Van schroom of achterhoudendheid was geen sprake. Alleen als er iets niet comme il faut moest gezegd worden, schaamde men zich daarvoor, en dat werd mij dan langs een omweg, of in bedekte termen verteld.

Bij het verhalen had ik altijd mijn oudsten pleegzoon bij mij. Deze, dien ik in 1883 als 8 a 9 jarige knaap uit de slavernij had losgekocht, heeft een aangeboren aanleg voor taal, en was ons steeds bij het aanleeren der ongeschreven Windèsische taal een goede hulp.

Bij het opteekenen ging ik aldus te werk: eerst liet ik den verhaler het heele verhaal aan ons vertellen, waarbij ik korte aanteekeningen maakte. Daarna verzocht ik hem het nog eens, maar nu zin voor zin te vertellen, onderwijl ik het met mijne schrijfmachine noteerde. Dan bleek het nut van de aanteekeningen. Door de ongewoonte het zoo langzaam te vertellen, of 
omdat hij het vervelend begon te vinden, vergat de verhaler wel eens wat, of raakte in de war; doch dan werd hij door ons tot de orde geroepen, dewijl wij den draad reeds in handen hadden.

Ik teekende letterlijk op. Stijl, woordkeus en uitspraak zijn in elk verhaal van den verteller zelve. Deze amissi zijn alzoo geheel oorspronkelijk, ongecorrigeerd en onversneden. Mij dacht dit het beste voor den taalkundige die ze tot een onderwerp van studie wil maken.

Als een amis opgeteekend was las ik het aan den verteller voor, en dan was het soms de moeite waard te zien welk een indruk het weergegeven verhaal op den verteller maakte. Steeds geraakte hij of zij dan meer of minder in extase, waarbij uitroepen van vreugde en instemming niet ontbraken.

Ik ben niet zoo gelukkig naar een spraakkunst te kunnen verwijzen. Tot het samenstellen daarvan achtte ik mij incompetent. Den besten tijd mijns levens heb ik moeten besteden aan zwaren handenarbeid. Tot tweemaal toe werd ik geroepen op het onherbergzaam Nieuw Guinea een nieuwe post te stichten: in 1884 op het eiland Roon, met wijlen den Zendeling Bink samen, en in 1889 alleen te Windèsi. Het veroveren van een terrein daarvoor op het oerwoud en het bouwen van huis, kerk, school en wat er verder noodig is op een zendingspost, en dat zonder eenige hulp van elders, in een koortsklimaat, kost teveel lichaamsinspanning om lust of kracht over te laten voor gezette studie. Het bouwmateriaal dat ik behoefde lag bij mijn komst ter plaatse nog verspreid aan 't strand of op de koraalbanken, of stond nog te groeien in 't bosch. Ik vlei mij echter in dit en ander werk, bijv. een bundel Bijbelsche geschiedverhalen, uitgegeven door het Ned. Bijb. Gen., wel eenig deugdelijk materiaal te hebben verschaft voor dieper gaande taalstudie dan waaraan ik mij durfde wagen.

Daar verreweg de meeste lettergrepen op een klinker eindigen, moesten we bij het in schrift brengen der taal ons bedienen van diakritische teekenen. Voor de uitspraak diene dat:

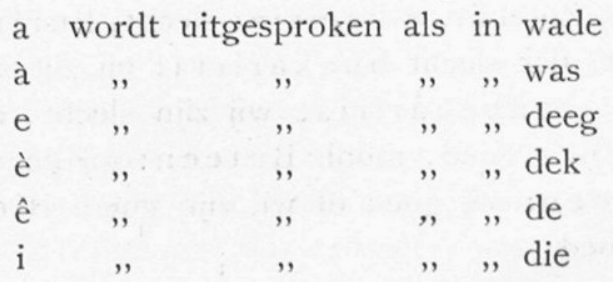




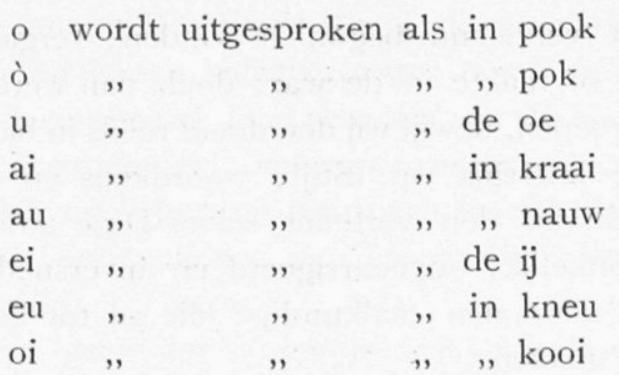

Verbuigingen kent het Windèsisch niet. Als voorbeelden van werkwoord-vervoegingen diene:

òsa = staan. Enk.v.: jòsa, buòsa, diòsa. Meervoud inclusief: tantòsa, exclusief: amantòsa, mentòsa, sentòsa. Tweevoud inclusief: tunròsa, exclusief: amunròsa, munròsa, sunròsa.

bò $=$ roeien. Enk.v. : ibò, buò, biò. Meerv. inclusief: tanbò, exclusief: amanbò, menbò, senbò. Tweevoud inclusief: tunbò, exclusief: amunbò, munbò, sunbò.

ra = gaan. Enk.v.: ira, rua, ria. Meerv. inclusief: tanda, exclusief: amanda, menda, senda. Tweevoud: incl. tunda, excl. amunda, munda, sunda.

Voor tijd en wijze ondergaat het werkwoord geen verandering. De tijd moet uit den zin blijken. Door een praefix, of door een volgwoord wordt daaraan te gemoet gekomen. Als praefix, schoon schijnbaar infix, wijl het tusschen het v. n. w. en 't werkw. komt, wordt: $t$, ta, ti, to, gebruikt om ongeveer het bedrijvend deelwoord aan te duiden.

Door het werkw. door pena, verkort pe te doen volgen duidt men het bedrijvend-door to en pana, verkort $\mathrm{pa}$, het verleden deelwoord aan. $\mathrm{Nani}$ duidt den toekomenden tijd aan, en rèto de aanvoegende wijs. $\mathrm{Ba}$ als suffix is de negativus, en pênai of mojar de negatieve imperatief. Een positieve imperatief wordt door den nadruk of de stemverheffing openbaar.

Eenige bijv. n.w. worden, zelfstandig gebruikt, als werkwoorden behandeld. Het praefix be, soms wel, soms niet als werkwoord vervoegd, kan met het hulpwerkwoord: worden of zijn vertaald worden. Zoo bijv. is kariria: slecht, kuriria, kiriria: gij of hij slecht, dat slecht buekariria: gij zijt slecht, of: er slecht aan toe, tanbekariria: wij zijn slecht, of: er slecht aan toe. Ateen is goed, mooi. Buteen: gij goed of: gij zijt goed. Tantateen: wij goed of wij zijn goed. Bieateen: hij of het wordt goed. 
Voor het accent zijn geen vaste regels aan te geven. Bij eenige woorden die tweeërlei beteekenis hebben, wordt door het accent de bedoeling bepaald Bijv. sasi met den nadruk op de $\mathrm{a}$ is zee of zeestrand, sasi met den nadruk op de $\mathrm{i}$ is drek of het werkwoord: afgaan of flatuleeren. Ik meen te mogen zeggen dat het Windèsisch, uitgesproken zooals het geschreven is, overeen komt met de door het volk gesproken taal.

Indien ik door deze verhalen voor de taalwetenschap, en voor den Zendingsarbeid wat goeds heb mogen doen, zal dit mij ten zeerste verheugen.

\author{
J. A. VAN BALEN
}

Oud.Zendeling. 


\section{Inuri.}

Inuri nia na Rumberpon. Sianina raarwo bwabwin tòru. Inuri siaw babapai, diò riaut $\mathrm{i}$, bape kimberrei, diò: tëi riaut tawai jani? Iraut sinjontupaisi bai? Tawai nini imateit i. Inuri siaw be mònupai, bape kimbèrei $\mathrm{i}$ ja, kibeo tapě babapai, diò: tëi riaut tawai jani? ikemberei i! Inuri siaw bemadjawipai, i ma miajar, tiòpan: tawai ninaò iraut i sarědjeu! Kapa ninaò, iraut i sarědjeu! Wona ninaò, iraut i sarědjeu! Wangar ninaò, iraut i sarědjeu! Dieuso babai sanu: tawai ninaò mumateit $i$, iraut $i$ sarědjeu! Inuri riaut $i$, diru surena, bië sinjontu, sasaar siuwa na soorpai, bië tawai, diru soorpai biata, bië sinjontu ja.

Aborè diròpai sanu sunbò arau, sunkoor pirië. Sunkoor si are, suntinunum pi sentaan. Inuri diaan pirië, diaan wěsjeen. Aborè Inuri tiòpan: pirië nino diteen beja! Pau te? Inuri diaan esia bai? Diròpai suntòpan: pau! Kausapa tanbò tankoor esi ja. Inuri tiòpan: nani jotě manu!

Inèni kausapa senbetòru senbò, sunròně Inuri nia na waponpai, na aisasè raròpai, kiriawasi na aisasè raròpai to diònu, pirawan rupai na aisasèpai babopai. Diròpai sunkoor sumbeerpèsi sunraniwar i na seraui rarò.

Inèni senbetòru senbò. Inuri titira, sijoor pirië katu, tiòpan: esi niwani! tankoor i bai? Diròpai suntòpan: bibaba! tanbabur i, nia i! Senbò ja, sijoor katu esia, tiòpan: tankoor nini bai? Diròpai suntòpan: bibaba! mojar! nia i! Senbò ja, inèni sijonr mukubaipai, tiòpan so dirò sanu: pimasa nini tankoor $\mathrm{i}$ bai? Diròpai suntòpan: jò! tankoor i! Diutan sanu: nani tankoor i tanè? Inèni diròpai sunramis i sunròtò: kubira! Sunraniau i: kubira awab, kuri na tabatěpai! Inèni kiubir awab; ma kirib na tabatěpai, mukubaipai kiumu tawan Inuri rupai! Inèni diròpai sanu sunsepar serauipai so sumbeerpai, esi dipai apon, piëran tituwi Inuri bië rabibwam. Rabwan esi bië bata, rabwan esi bië wana, rabwan esi bië djòběra, rabwan esi bië kruja, rabwan esi bië kabjebar, rabwan esi bië masaso, rabwan esi bië diaan kariria, rabwan esi bië kumdare. Siusar diròpai sanu are, sunbabur to sunsuwar, sunrin babur so nupai rarò. Rabwan bië bata kiaar Jeninbere, sentap rewu nini: Inuri kiaar i! 


\section{Vertaling:}

Inoeri woonde te Roemberpon. Daar waren drie zusters. Inoeri vroeg de oudste, willende haar trouwen, maar zij wilde niet, zeggende: wie trouwt zoo'n slang? Ik trouw mannen, niet? Deze slang vrees ik! Inoeri vroeg de tweede, maar die wilde weer niet, sprekende als haar oudste, zeide zij: wie trouwt deze slang? Ik haat ' $m$ ! Inoeri vroeg de jongste, en die wilde, zeggende: deze slang! ik trouw hem maar! Was hij een hagedis, ik trouw hem maar, was hij een hond ik trouw hem maar, was hij een muis, ik trouw hem maar. $Z_{i j}$ verweet de beide oudsten: deze slang, gij beiden, vreest 'm, ik trouw hem echter! Inoeri trouwde haar: 's nachts als zij sliepen, werd hij een mensch, bij 't daglicht stak hij zich in zijn huid, dan was hij slang, 's nachts lag zijn huid, dan was hij mensch.

Toen, roeiden de beide zwagers naar zee, zij haalden schelpdieren. $Z i j$ brachten ze aan land, zij poften hun eten. Inoeri proefde de schelpdieren, zij smaakten goed. Nu zeide Inoeri : deze schelpdieren zijn erg goed! Zijn er veel? De zwagers zeide; veel! Morgenochtend roeien wij en halen weder andere. Inoeri zeide: ik roei met $\mathrm{u}$.

Toen, den volgenden morgen, zij drieën roeiden, deden zij Inoeri plaats nemen vóór in de prauw in 't voor-opzetstuk; hij schoot zich in het voor-opzetstuk op, tot het vol was, leggende zijn kop op (de rand van 't) voor-opzetstuk. De beide zwagers namen kapmessen mee, verstoppende die in het zeil. Vervolgens roeiden zij drieën. Inoeri uitkijkende zag een kleine schelp en zeide: daar is er een! nemen we die mee? De zwagers zeiden: die is niet groot! wij gaan verder! die blijve! Weder roeiende, zag hij een andere kleine, en zeide: nemen wij die niet mee? De zwagers zeiden: die is nîet groot! niet doen! die blijve! $\mathrm{Zij}$ roeiden weder, toen zag hij een reuzeschelp (tridacnaof chama-gigas) en zeide tot zijn zwagers: deze groote, nemen we dle niet? De zwagers zeiden: ja! die nemen we! Hij vroeg hen: hoe zullen wij die nemen? Toen zonden de zwagers hem, zeggende: duik onder! $\mathrm{Zij}$ onderrichtten hem: duik naar beneden, bijt in de dwarsche (sluitspier)! Toen hij onder dook en beet in de sluitspier, kneep de schelp Inoeri's hoofd vast! Toen ontrolden de beide zwagers het zeil om het kapmes, één liep snel naar voren, en hakte Inoeri tot moten. Één moot werd 
een brandingsgolf, één moot werd wind, één moot werd regen, één moot werd donder, één moot werd bliksem, één moot werd een waterhoos, één moot werd een krokodil, één moot werd een bruinvisch. Zij joegen de zwagers beiden landwaarts, die vluchtten tot zij binnen liepen; zij wisten te vluchten tot binnen in het eiland. De moot die brandingsgolf was geworden, schoor (het eiland) Jeninbere.

Men noemt die kaap: Inoeri schoor haar.

PS. In 86 langs Jeninbere's noordpunt varende vertelde mijne roeiers, allen Rooners, dat Inoeri zelf die rots had kaal en glad geschuurd met zijn staart, toen zijn kop in de schelp zat vast geklemd.

\section{Bwabwin Amoria.}

Manbesawa Windèsi sunbò, sunperan wa na Wanduni: Sunperan to měnau, sunkoit. Menau rawiniena sunbabur, Bwabwin Amori rieeb kakò, surena napa. Saar sunbò, sa ja, tapèna ja: muan biata tuter bwinieempi ja, tapè papon. Rawiniena sunbabura ja, Bwabwin Amori siubi ja, rieeb kakò sunrena napa ja. Raria wura tapèna, to Bwabwin Amori diawin, diawin sinjontu wàtan. Bwabwin Windèsi diawin kòta, sanu wura sunrabwin masis baberi.

Bwabwin Amori misoi tuter aantumpai to biba. Biba pa aantum ria rau, miun pi, sinjani misoi na dorepai. Miun pi to rairu pa, bibur so sinjani, aantumpai niunum diaanpai siěmuai to, diònè sinjani sunraan si. Sunrena to kausapa, sumasoi to djèpai sinaja, aantum ria rau, miun $\mathrm{pi} \mathrm{ja}$, to rairu riama re ja, biburi ja so sinjani, riuri ja adiapai, dinunum diaanpaisi, diònè sinjani suraan si. Sunraan pi to, diru surena ja to kausapa. Inèni sinjani sunda wura arau, sinjani misoi na rubwanpai, aantumpai ria rau, miun pi ja,

Kabò Windèsipai sentonbò aji, sentò senmun pi, sensajoor marariapai. Rawiniena senbaburi ja maso sennè aniopaisi. Rawiniena sentatòpan marariapai siubi miun pi pa. Sentutan babera siat: tatat esi ni raria nè, amansajoor $\mathrm{i}$ wa te? Esipai siat sentòpan: hei! tanrin i ba! sinjontu biò siubi na nina te? Ma mojar! Kausapa tanbò, tantaramaan i. Inèni kausapa sensjaar wapai sura, senbò aji, sentamaan i.

Marariapai sinjani sanu sumasoi to djèpai sinaja, sunda ja 
rau, sinjani misoi na rubwanpai, mararia ria ja rau, miun pi, pir atopaisi tuter sinjani, misoi tuter si. Ria mium pi to, inèni raitpai sentau so i, Ruran jani, tiau arau, sentò sentapur i. Bape diana, ruran jani misepar, bibur. Ruran esipai sentau i ja, bape diana siat, i ja senmasepar, bibura ja, to ruran be tòru sentapur $i$, senkoor $i$, senbabur ma so Windèsi, senkoor i so tamani. Bwabwin Windèsi nièpai, Bwabwin Amori nièpai, sunmasoi to sunbesinjontu.

Sunbesinjontu baba to, inèni sunkabio sunberait. sunmun aniose borei nèsi wura: Rapat, Maněkioon, Sjari, Waraja, Wairor, Wepu, Rumberpon, Roswaar, Maso, Wandàmen, Waropen, sinjonde, bena sasi, siat wura. Sisindjori, Bwabwin Amori aantumpai, tipur womenpai mònu, Maniwori, bwawin Windèsi aantumpai, tipur siri wenasja. Sunbabur maso anio, sunbò sa ja, sunberait ja, Sisindjori tipur tòru, Maniwori tipur mònu. Sunbabur maso aniopai, sunbò sa ja, Sisindjori tipur at, Maniwori tipur tòru. Sunberait tawana, Sisindjori tipur pau raiwain Maniwori, to Maniwori kisjo. Inèni tiòpan so Sisindjori, diò : tunmun rawanam rau ri. Sunbò so Nufori, Sisindjori tipur sinjontu siri, Maniwori tipur sura. Raitpai bibur ma re so Manem Maniwori tiòpan so Sisindjori: tantaboi, tantena. Inèni sentena. Sisindjori diena to dienasiat, Maniwori diòne senbabur i senkoor Sisindjori niè andio, tariwan, airiwan, atopaisi, apapai sibata tuter i. Inèni sensa, senbaburi.

Kausapa Sisindjori tindo, siserrei siat, kisjo, kibeo babera na mitauni, tiòpan: babai diawi jau, senbabur jau! Mièser i misoi, raitpai bibur maso Wasambin sentaboi. Sendurě wura, senbaun rewu pon i. Bwabwinpai siat sentadjawa tabura, senbò so siat. Raitpai senbò ma so Djubiri, bwabwinpai siat senbò apon so siat sentutan raitpai, raitpai miun toi? Raitpai tiòpan: Sisindjori tipur sinjontu siri, Maniwori tipur sura! Maniwori tiòpan: amamum aniose to kariria, sentana Sisindjori to biòru! Bwabwinpai siat sensobera ma so aniose pò, sentòpan: senmun aniose $\mathrm{Nu}$ fori to kariria! Sisindjori tipur sinjontu siri, Maniwori tipur sura, ma Nuforipai siat sentana Sisindjori to biòru!

Bwabwin Amori didjawa sentòpan aantumpai biòru, sïeis. Bwabwin Amori sinur kasinamsi, sirio si, kiòpas so sasipai, diaas, sïeis, diòjò: Bwabwin Amori sinur kasinam, diaasě rawanam mirandaan $i$ to jò? Diaase, sïeis rari to Warasòrè, inèni pir i, diaas arau so nu Nufori, sieis wora. Tapèna diaas to 
piapar nu Nufori, wara siawa na rewupai Inariori, so mirioor. Ma wara roür tansajoor $\mathrm{i}$ rami na rewuki na rewu Inariori. Inèni ria re, ria sieis, sisěrei aantumpai. Aantumpai diëna, sinjani ria, sieis to didjawa i. Inèni Sisindjori diòsa, kisjo sinjani, tiòpan: sjettanpai! bwisaar bekaririonapai! sueis so? Sinjani tiòpan: ira isaserei au, so mèmu babai diòjò: Nufoorpai siat sentana au to buòru. Kabò Sisindjori tiòpan: diawi jau! diò nanè amantena na Manem, jenasiat senbabur jau. Sunkabio to měnau, inèni sinjani siaw aantumpai, diòtò: ruama tuòta jau. Aantumpai tiòpan: itòta au worè nani i tanè? Bape sinjani diòtò: tuòta jau saredjeu. Sinjani diniau aantumpai: tuòta jau, buon 'nanaria runè, inè aibo, karusina, samasina, puïr si sibata wèsje, inè těrai baba nini kutu $\mathrm{i}$ to keis mididjawi, inèni rua, buoob $\mathrm{i}$ ariri ai sopè nèsi. Inèni aantumpai nianari tapè sinjani diniau i. Inèni kioor sinjani rupai, karusinapai, aibopai, samasinapai, pir si sibata na rabwan. Inèni ria, bioob těraipai wura, esa bata na ai sopè, esa bata na ai sopè, to ai sopè borei simasis wura, Inèni diru diena to deriasi kausapa, diòtabia, tiòpan: aniose nè mentena è? Mentòsa abo tanmun maroba! Inèni kawàsapai sentòsa wura: niè sinjani těrai bibesinjontu, sibeanio, sibewa, mantaun niè sinjani sunnè aniopai nia rabwan. Inèni sennanari wapaisi senbos wa sinjontu rim, senbò mare so Windèsi, senmun Windèsi. Senmun siat to měnau, senbabur i ja arau, sentimasoi na Nufori.

\section{Vertaling :}

Vrouwtjes kangoeroe.

Een Windèsisch echtpaar roeide (om een) prauw (te gaan) hakken naar Wandoeni. Toen zij genoeg gehakt hadden legden zij zich te samen (coitum exercent). Des avonds eindigende gingen zij weg, en likte Bwabwin Amori het sperma waar zij gelegen hadden. Den volgenden morgen roeiden zij weder, doende weer zoo: toen de man gehakt had, sliep hij weder met zijn vrouw, gelijk tevoren. 's Avonds vertrokken zij weder. Bwabwin Amori kwam weer te voorschijn, en likte weer waar zij gelegen hadden. Alle dagen ging dat zoo, tot Bwabwin Amori baarde, zij baarde een echt mensch. De Windèsische vrouw baarde ook, zij beiden baarden geheel overeenkomstig. Bwabwin Amori bleef in 't bosch met haar kind tot het groot was. Groot zijnde ging de jongen zeewaarts visch vangen; de moeder bleef in 't bosch 
('t land). Hij ving visch tot den vloed, en keerde (tuen) weder tot zijn moeder. De jongen pofte de visch die hij gevangen had, hij gaf (ook) aan zijn moeder, zij aten te samen. Zij sliepen tot den morgen, zij vertoefden tot het laag water was, de jongen ging zeewaarts, ving weer visch tot de vloed landwaarts kwam, hij ging weer tot zijn moeder, stak weer vuur aan, pofte de visschen, gaf aan zijn moeder, zij beiden aten ze. Toen zij gegeten hadden sliepen zij 's nachts weer tot den morgen. Toen gingen zij samen naar zee, de moeder zat op het zand, de jongen ging buiten weder visch vangen.

$\mathrm{Nu}$ roeiden Windèsiers naar boven (zuidwaarts) om visch te vangen, en zagen dien jongen. Tegen den avond gingen zij weer terug naar hunne huizen. 's Avonds vertelden zij van den jongen die uit was gekomen om visch te vangen. $\mathrm{Zij}$ vroegen elkander: kan dat een van de onzen geweest zijn dien wij daar zagen? Anderen zeiden: hé! wij weten het niet! Roeide er iemand van hier uit? Wel neen! Morgenochtend roeien wij en bespieden wij hem. (of loeren op hem)

De jongen met zijn moeder vertoefde tot het strand droog was, en zij gingen toen naar buiten; de moeder zette zich op het zand, de jongen ging weer naar buiten visch vangen, zijn pijlen legde hij bij zijn moeder om er op te passen. Hij vischte, toen de rooftocht hem overviel. De afdeeling die hem van de zeezijde aanviel, wilde hem vangen. Maar hij schoot (met pijlen) op deze afdeeling, die ging uiteen en vluchtte. Een andere afdeeling viel hem weer aan, maar hij schoot op hen en die, zij gingen ook weer uiteen, en vluchtten weder, tot de derde afdeeling hem ving, en hem meenam. $Z_{i j}$ vertrokken naar Windèsi, en zij brachten hem bij zijn vader. Die jongen van de Windèsische vrouw, en die van Bwabwin Amori, zij beiden bleven tot zij mannen waren geworden.

Toen zij beiden groot geworden waren, toen spraken zij af raak (rooftocht) te maken, en overvielen velen dezer kampongs Fak geb, Maněkioon geb, Sjari, Wariab, Wairor, Wepu, Roemberpon, Meoswaar, Roon, Wandàmen, Waropen, boschbewoners, strandbewoners, die allen! Sisindjori, Bwabwin Amori's jongen, ving twee slaven; Maniwori, de zoon der Windèsische, ving er slechts één. Zij keerden terug naar huis, en zij roeiden weder op raak. Sisindjori ving er drie, Maniwori ving er twee. $\mathrm{Zij}$ keerden huiswaarts, en roeiden weder. Sisindjori 
ving er vier, Maniwori ving er drie. Dagelijks gingen zij op raak. Sisindjori ving er veel meer dan Maniwori, totdat Maniwori boos werd. Toen sprak hij tot Sisindjori zeggende: wij gaan strijden ginds over zee! $\mathrm{Zij}$ roeiden naar Noefoor, Sisindjori ving één man, Maniwori ving er tien. De raak vertroh naar Manem. Maniwori zeide tot Sisindjori: laten wij ankeren, en slapen! Toen zij sliepen, Manimori sliep zeer vast, deed Maniwori hen hem verlaten. Zij brachten Sisindjori's slaapmat, deken, hoofdsteunsel, pijlen, en boog, en legden die bij hem neer. Toen gingen zij en verlieten hem.

's Morgens ontwaakte Sisindjori, hij zocht hen; boos zijnde sprak hij tot zichzelven, zeggende: mijn oudste broeder heeft mij belogen! zij hebben mij verlaten! Hij bleef alleen, en de raak vertrok naar Wasambien (waar) zij ankerden. Allen bijeen zijnde, deden zij de voorste kaap opschrikken. Toen de vrouwen de tritonschelp hoorden, roeiden zij tot hen. De raak roeide tot Djoebiri, toen de vrouwen hen bereikten, en de raak vroegen: hoeveel heeft de raak gekregen? De raak zeide: Sisindjori ving één man, Maniwori ving er tien! Maniwori zeide: wij hebben de kampong uitgemoord (gedood tot slecht, of: tot bedorven) (maar), zij hebben Sisindjori doodgeschoten! De vrouwen keerden weder naar de kampong, zij zeiden: zij hebben de kampong Noefoor uitgemoord! Sisindjori ving één man, Maniwori ving er tien, en de Noeforen hebben Sisindjori doodgeschoten!

Bwabwin Amori hoorende dat zij zeiden dat haar zoon dood was, weende. Bwabwin Amori reeg komkommers aaneen, deed ze aan haar hals (als collier), sprong in zee, zwom weenende, zeggende: Bwabwin Amori reeg komkommers aaneen, zij zwemt in zee, tot waar toe zal zij rond drijven (z. a. wrakhout ronddrijft). Zij zwom langs de kust tot Oranswari, toen stak zij af, zij zwom zee in naar het eiland Noefoor, al jammerklagende. Zoo zwom zij tot zij Noefoor naderde, waar zij met de handen ging hangen aan kaap Inariori, vermoeid zijnde; en de indruk der hand is nog te zien in den steen aan kaap Inariori. Toen ging zij het land in, gaande al weenende, zocht zij haar zoon. De zoon sliep, (toen) de moeder liep te weeklagen tot hij 't hoorde. Toen stond Sisindjori op; boos op de moeder, zeide hij, Satan! slecht oud wijf! waarom huil je? De moeder zeide: ik ben je gaan zoeken, want je oudste broer zegt: de Noeforen 
hebben je doodgeschoten. Nu zeide Sisindjori: hij beloog me! hij zei dat wij op Manem zouden slapen; toen ik vast sliep verlieten zij mij. Toen zij beiden uitgepraat waren, toen verlangde de moeder van haar zoon, en zeide: kom! hak mij stuk! De zoon zeide: als ik u stuk hakte, hoe zou het mij dan vergaan? Maar de moeder zeide: hak mij maar aan stukken. De moeder onderrichtte haar zoon: hak mij aan stukken, doe voorzichtig met mijn hoofd, mijn hart, mijn ruggegraat, mijn heiligbeen, leg die, dat zij apart liggen, het (andere) groote deel van mijn lichaam snijd dat aan kleine stukjes, dan ga, verdeel het overeenkomstig de boomstronken hier. Toen deed de zoon zooals zijn moeder hem had onderricht. Daarna nam hij zijn moeders hoofd, ruggegraat, hart, en heiligbeen, en legde ze in het midden. Toen ging hij het heele lichaam verdeelen, bij elken boom legde hij een stuk, totdat de boomen allen gelijkelijk hadden. Dien nacht sliep hij tot tegen den morgen, stampte met den voet, zeggende: deze kampong! slapen jelui nog? Staat op! opdat wij onzen oorIog uitveehten! Toen stonden al de menschen op: was zijn moeders lichaam geworden: menschen , huizen en prauwen; zijn moeder (en hij) zij samen hadden het huis staande in 't midden. Toen bereidden zij de prauwen en roeiden met honderd prauwen; zij roeiden landwaarts naar Windèsi, en bevochten Windèsi. Toen zij eindigden met vechten, vertrokken zij weder naar zee, en bleven op Noefoor.

\section{Maranisiat ma bebabaarpai.}

Waibwini, bwabwin Windèsi, diawin sinjontu wàtan tuter pisibara. Pisibara wara wàtan tieitu kimburu. Bwabwinpai diaum sanu wura: pisibara diunum susu sara, sinjontupai diunum susu wàtan. Bwabwin siòibi sanu wura na paarwasi bekabiri siri, sunbata ja. Diaum sanu tawana to sunbaba wura. Pisibara diunum susupai, kirip i wora to bibara biëkapor. Waibwini tiòpan so kawàsa: mendama! menkoor $\mathrm{i}$ arau so nu wa, menpir $\mathrm{i}$ bia na. Inèni senpir i na paarwasipai, senkoor $i$ arau, senpir i na nu rau.

Bebabaarpai sipop rusar Wadjeu arau, to sijoor Wadjeu bia napa. Inèni bibur mare so anio Maranipaisiat. Bebabaarpai tiòpan so Maranipaisiat: nani esi biòru, menkoor i, menpir i na nu rau, menkoor i, pandòtu kòta menbaar i tuter bebòrupai arau, menbabaar i na rawesi siri, abo Wadjeu sijoor ririn i. Wadjeu 
nani tiòpan: apusi esi nina, abo ikai i pěnai, biata. Wadjeu siaji, tipur $i$, rieeb $i$, inèni biaar bibura ja so niè kamberrepai. Bekoor bebòrupai senbabur mare, senbaar pandòtu to aniopai, sensa anio, sensiaw pandòtupai na anio, dibakiri to raria, babapèsi biaar besiri, misoi to, katu biaar $\mathrm{i}$ ja, senbubu kambo na paarwasi bekabiri, sentisan gondipai na raròpai, sensòkiaar riòtu tuter pandòtupai.

Ma so bebabaarpai diniau Maranipaisiat sensaw bebabaarpai be tapu. Ma bebabaarpai tiòpan siat: mentaan jau penai! mennèwòri jau! So nini Maranipaisiat sensajoor bebabaarpai penai: sensajoor i, esi biòru.

\section{Vertaling:}

De Maraniërs (een Windèsisch geslacht) en de kroonduif.

Waibwini, een Windèsische vrouw, baarde een echt mensch (kind) en een leguaan. De rechtervoorpoot van den leguaan was een stomp. De vrouw voedde ze beiden: de leguaan dronk de linker-, het kind de rechterborst. De vrouw baadde ze beide in een kom en legde ze weder neder. $Z$ ij voedde ze dagelijks tot ze beide groot waren. De leguaan, drinkende (aan) de borst, beet er aldoor in, tot zij opzwol en wond werd. Waibwini zeide tot de menschen: komt hier! brengt hem naar buiten op dat eiland daar! legt hem daar neer! Toen legden zij hem op een bord (of schotel), brachten hem zeewaarts, en legden hem op het eiland daar buiten.

Een kroonduif vloog Wadjeu (naam van dat eiland en van de leguaan) zeewaarts tot zij zag waar hij lag. Toen ging zij landwaarts naar het huis der Maraniërs. De kroonduif zeide tot de Maraniërs: als er iemand sterft, brengt hem en legt hem op dat eiland daar, hem wegbrengende, slaat ook de trom bij den doode, naar buiten varende, slaat de trom aan ééne zijde van den doode, opdat Wadjeu hem herkenne. Wadjeu zal dan zeggen: dat is een mijner kleinkinderen, ik zal hem niet wegwerpen, hij ligge! Wadjeu (zal) opklimmen (n.l. op de stelling waarop het lijk is neergelegd), hem omarmen, hem likken, daarna afklimmen en teruggaan naar zijn hol. Die den doode wegbrachten, terugkeerende slaan de trom tot aan 't huis, stijgen 
in 't huis en hangen de trom op in 't huis, zij hangt daar tot 's middags een volwassene er éénmaal op slaat, vervolgens neder zit, en kort daarna, weer slaat; dan giet men water in een kom (schotel), steekt er een rietstok (een rietsoort waarvan men pijlen maakt) in, en wrijft (krast) daarmede om geluid te geven met de trom.

En dewijl de kroonduif dit onderricht gaf aan de Maraniërs, noemen zij een kroonduif: grootvader. En de kroonduif zeide tot hen: eet gijlieden mij niet! houdt gijlieden mij voor onrein! (of heilig) (taboe der Polynesiërs). Daarom mogen de Maraniërs de kroonduif niet zien: zien zij haar dan sterft er iemand.

\section{Bwabwin sanu sunbeabo.}

Muan bebaba, muan sanu, sunraweer, sunmun pimunapèsi, sunsòbin i. Muan bebaba, bwabwinpèsi sanu, suntapur kawe na raròpai, sunda sunmasoi na jabar muan sanu sunnèpai. Babai biëabo beürar, madjawi biëabo bèsa, ma muanpai sanu sunda ja sunraweer, bwabwinpai sanu sunbeabopai sunrin bata. Muanpai sanu sundama sunkoor pimunapèsi, sunkai i awaab, sunnunum i na jabar dirèpai. Aborè madjawi sijoor rwapir, tiòpan so babai: abo sanu sunbata rarò wana, tei pir sanu nè?

Diru muan sanu sunrena, abo beürarpai diòsa, ria diëna tuter muanpai babai, abo bèsapai ria so muan bemadjawipai. Kausapa abopai sanu sunbesinjontu, muan babapai riaut bwabwin babaipai, ma madjawipai riaut bwabwin madjawipai. Sasaar senbabur so sennè aniopaisi, senmasoi na sennè aniopaisi.

\section{Vertaling :}

Twee vrouwen die zich in (eetbare) pandanusvruchten veranderden.

Twee broeders gingen samen op de varkensjacht. Die zij gevangen hadden roosterden zij. Twee zusters vingen garnalen in de rivier, zij gingen en verbleven in de hut van de beide manrien. De oudste werd (veranderde zich in) een roode (eetbare) pandanusvrucht, de jongste werd een gele pandanusvrncht, en toen de beide mannen weer varkens gingen jagen, legden de beide vrouwen die pandanusvruchten waren geworden zich neder. 
De beide mannen kwamen terug, dragende varkens; zij wierpen ze op den grond, en zij roosterden ze terzijde van de hut. Toen de jongste naarbinnen keek, zeide hij tot den oudste: die beide pandanusvruchten die daarbinnen liggen, wie heeft die daar gelegd?

's Nachts sliepen de beide mannen; de roode pandanusvrucht stond op en ging slapen met den oudsten man, de gele pandanusvrucht ging tot den jongsten man. 's Morgens de beide pandanusvruchten werden menschen, de oudste der mannen huwde de oudste der vrouwen, $\in$ n de jongste huwde de jongste der vrouwen. Toen het licht was gingen zij naar hunne huizen, (en) woonden in hunne huizen.

\section{Wòri Ingarurumi.}

Arowondai nianari andiosu so nie aantumbwabwin Raromboi na Parairawai, senmaji to diru. Ingarurumi riama so aantumbwabwinpai Raromboi, diena tuter i. Deriasi sasaar bibura ja, rawiniena riama ja ria bië sarata, riama so bwabwinpai bië sinjontu, to diru tòru. Raria beat bwabwinpai diawin aantumpai muan nina. Aborè raarwopai sijoor Raromboi sanèpai babapai, aborè tiòpan i so sinjani, sinjani tiòpan i so tamaani. Aborè sinjani tiòpan: esi riama so $\mathrm{i}$ ba! Aborè tamaani diutan aniosepai, siaaw: katimpai miat! esau rua so bwabwinkatu nè te? Sentòjò : plbai! amat pibai! amanrin i ba!

Mararia biba, siëis tamaani. Aborè sanaja sinjani biai i, sunda sasera tamaani, ria na jaarpai, sunda so tamaani. Aborè tamaani bië bata, ria mare, kioor sanu so niè aniopai. Inèni rioi so i diaan diaanpai, diòn'pi so Wapupi. Wapupi riamare diaan ròpai, kioor raarè so i. Aborè Ingarurumi kioor raarpai maso niònisiat: serakè, sampaarè, taba suraè, mamoraè, piësasi wura. Ria na wa beawaan, ria na sòrararòpai ma ji, riama diboi na niòni sennè aniopai reponpai. Aantumbwabwinpai kioor raarpai ma re so tamaani, sinjani, raarwopaisiat, sumòni sennèwi, diarum so siat. Inèni Ingarurumi biërwana mitauni, aniose nè sensajoor $\mathrm{i}$ wura.

Aborè Ingarurumi bwinieempi misoiriaat tamaani sinjani sanu. Ingarurumi berait miun Rapat. kioor women siri. Ingarurumi diniau bwinieempi, tiòpan: mumasoi, raitpai kioor manu ma kioor manu sarèdjeu: nani irama tu, ipariri manu. 
Inèni dipuria nina. Aborè raarwopai, katupai senbò so Sipurui rawa toraupai riaarpai. Rait Wasjorpai senko na Sipurui rawa torau, sentapur raarwosiat wura, senkoor siat so Wandàmen. Aborè bwabwinpai tamaani bios piriri siat, bape senmajar ba, senbedjoor siat. Biò be rariapai tòru, bape kioor siat ba. Biò to wapai berandumi. Aborè Ingarurumi niè raitpai tibera, sendoi majis. Amana niòni sentò to: raitpai kioor aantummu, diròmu bwinieemmu siat pa. Ingarurumi bibur arau so niè aniopai to, kausapa ria pui so Wandàmen, piriri siat. Amana senmajar ba, bibura ja to, kausapapai ria ja pwir bië wanam, bie bata, biur sòrè, bië rairui, riapwir tibubu so aniosepai, tiòtap utan Wandàmenpai, kioor bwinieempi, diròpai, aantumpai siat. Ingarurumi tiòtap utanpai, nianari $\mathrm{i}$ to kariria.

Reirupai kioor kawàsa so airawipaisi, senbòru wura: bemasoi paisiat pau ba. Ingarurumi bibura ja ma, kioor bwinieempi, aantumpai, diròpai, di taniwar siat na niè aniopai, biërwana so niònisiat ba, dinda ma re ba, dimènau.

\section{Vertaling.}

De zeegeest (klipgeest) Ingarurumi.

Arowonda' maakte een insòpi feest ${ }^{1}$ voor zijn dochter Raromboi bij de Parairawaiërs. Zij dansten tot 's nachts. Ingarurumi kwam tot het meisje en sliep bij haar. Dicht bij 't licht(worden) ging

1 Zulk een feest duurt ongeveer een maand. De meisjes die insòpi worden gemaakt, wordt, na eenige nachten zingen en dansen, een lap geklopte boombast om het bovenlijf gebonden, en zij worden in een klein hnisje afgezonderd, dat zij niet mogen verlaten vóór het feest ten einde is. Als zij iets begeeren of behoeven, kloppen zij op een gong, waarop dadelijk eenige jongens of jongelingen gereed zijn hare wenschen te vervullen, echter door het gevraagde van buitenaf aan te reiken. Moet het feest om een of andere reden worden bekort, dan worden wel de meisjes uit hare afzondering verlost maar dragen dan dat lijfkleed tot de bepaalde feesttijd is verstreken. Doel schijnt te zijn: een zekere standverhooging, en de kans hoogeren bruidschat te bedingen.

Er wordt gefeest, d. w. z.: een of meer nachten veel gegeten, gedanst en gezongen, bij het trommelen, en kloppen op gongs, voor: het eerst loopende verschijnen van een kind in de voorgaanderij van het huis; voor den eersten enkelring die het aan krịgt; voor de eerste maal dat het visch eet; voor het stukslaan van een te nauw geworden enkelring; voor het hoofdscheren;

Dl. 70 
hij weer weg, 's avonds kwam hij weer, hij ging als een slijmkwal, hij kwam tot het meisje als man, gedurende drie nachten. Den vierden dag baarde het meisje een kind, 't was een jongen. Toen de zuster zag dat Raromboi zwanger was ('n grooten buik had), toen zeide zij 't haar moeder, de moeder zeide 't aan den vader. Echter de moeder zeide: niemand kwam bij haar! Toen vroeg de vader de kampong, roepende: jongelingen gij! wie uwer ging tot mijn dochter? $\mathrm{Zij}_{\mathrm{ij}}$ zeide: neen! wij niet! wij weten 't niet!

Toen de jongen groot was huilde hij om zijn vader. Toen het laag water was nam de moeder hem op den rug, zij gingen zoeken naar den vader, zij liep op 't koraalrif, zij beiden gingen naar zijn vader. Toen werd de vader een golf, kwam landwaarts en bracht hen beiden naar zijn huis. Vervolgens zong hij voor hem (opdat) hij visch zou (mogen) eten, en gaf (ook) wat aan Wapupi '. Wapupi kwam landwaarts, at feest-eten, en bracht geschenken voor hem. Vervolgens bracht hij (lngaruruminl. geschenken aan zijn schoonouders: zilveren armbanden, schelpen armbanden, stukken katoen (van 10 vadem lengte), steenen potten (vazen) en vele andere dingen. Hij kwam op een vanzelf varend vaartuig, hij ging de zeestraat door, hij kwam en ankerde aan zijner schoonoudershuis (aan den) voorkant. De dochter bracht de goederen binnen aan haar vader, haar moeder, haar zusters, haar tantes, voor bruidschat aan hen. Vervolgens vertoonde Ingarurumi zich zelven aan de kampong, zij zagen hen allen.

Daarna verzorgde Ingarurumi's vrouw haar vader en moeder beiden. Ingarurumi ging op roof uit bij de Fakkers, hij bracht een slaaf meê. Ingarurumi onderrichtte zijne vrouw, zeggende: gij beiden blijft, (zoo) een rooftroep u beiden meè neemt die neme u beiden maar mee: Ik zal komen en ulieden bevrijden.

Toen kwam het middag-laag-getij. Toen roeiden de (vrouw's) zuster, de kleine, en zij naar Sipurui's zeezijde's zandstrand.

voor het doorsteken van het neus-middelschot of van de oorlellen; voor het aandoen van den eersten scheamte-gordel; enz. Daar de deelnemers aan het feest geschenken geven, is veel feesten geven een niet onvoordeelig zaakje. Dat zulke feesten elke ontwikkeling belemmeren is duidelijk.

1 Wapupi is ook een zee- of klipgeest. 
Een rooftroep van Wasjor loerde aan Sipuru's zeezijde, zij vingen de gezusters, zij namen ze mee naar Wandàmen. Daarna roeide vader der vrouwen om ze in te lossen, maar zij (de Wandàmers), wilden niet, zij verhinderden ze. Hij roeide drie dagen maar bracht ze niet mee. Hij roeide tot zijn prauw met zeeruig was begroeid. Ingarurumi's rooftroep keerde terug, zingende aankomende. Toen zeiden de schoonouders: een rooftroep nam uw kind, uw zwagerin, uw vrouw; allen mede. Ingarurumi ging naar buiten in zijn huis, 's morgens roeide hij naar Wandàmen om ze in te lossen. Toen zij niet wilden ging hij weer weg en met den morgen ging hij weder (de baai) in: hij werd wind, hij werd golven, hij maakte stormgeluid met den mond, hij werd vloed die inging en zich uitstortte op de kampong, afbrekende het land Wandàmen, hij nam mede: zijne vrouw, zijne zwagerin, zijn kind, hen allen. Ingarurumi brak het land af en maakte het slecht (vernielde het). De vloed bereikte de menschen in de boomtakken, zij stierven allen: die overbleven waren niet velen. Ingarurumi ging weder weg hierheen, nam mede zijne vrouw, zijn kind (en) zijne zwagerin, verborg hen in zijn huis, ${ }^{1}$ hij vertoonde zich aan zijn schoonouders niet, ging niet hierheen landwaarts, 't was uit.

\section{Wòriboi.}

$\mathrm{Na}$ papon anina kankani baba besiri, misoi na Wapupi sama baba rau. Raria wura riama abo tipur kawàsa ma kioor siat ma diaan siat, ma tapèna kawàsa wura senbòru to senkeis, siri misoi ba, bwisaar siri mièser tuter aantum tapupai. Sanu mèser sunmasoi, sunraniwar sanu na anioraròpai, ma na diru sunnunum pi ma sasaar sunsepar adia abo tiup ba. Bape raria siri bwisaar tiòpan maso tapupai: rua so tapumui masaar Wòriboi, tuòpan so i. Mararia ria ma tiòpan: mamberobi! kankanipai miun aniose raudjaan to keis»! Masaar Wòriboi didjawa nini, piasa niè rupai, ma riut $\mathrm{i}$ na warapai, pir rèpai sanu na aròpai, siri na wara wàtan, ma esi na wara sara, ma kioor sanainioi, riausaar marariapai. Ma sundama to na anio, Wòriboi tiòpan so bwisaarpai: mundur adiapai abo tiup! ma mi

${ }^{1}$ Het huis van een wòri of klipgeest is de klip bij het eiland welks naam hij draagt of dat naar hem is genoemd. 
tauni sia na aniobabuan, sièwar nandau ma misoi ma diramaan kankanipai. Sajoor! kankanipai sijoor adia tiup, riama ma riama deriasi, masaarpai siòwòtu aròpai na sanainioi, ma kankani biòru. Ma bwisaarpai tuter tapupai sunrapai ma sunperan kankani, suntòtai $i$, ma sunboob i ariri aniosi si bareri. Nini keis, masaar Wòriboi siaaw maso bebòrupaisiat: tanda! tantara! Bape sendaar ba. Bape siaaw ja: tanbò! tantadu! Ma besiri sentòsa senkajajera, ma sensjaar wapaisi, ma sentuaar, ma senbò abo senkoor anam. To raria nini rami tapènina na aniose Windèsi: senbaro seeri bape sensânèwèsjeen senbò wenasia abo senkoor anam, so sentadjawa ba maso masaar. Wòriboi kioor kankani rupai, ma disan i na sanainioi ma bibur ja so niè utan Saserkatu, anina deriasi napènina.

\section{Vertaling :}

Tc voren was er een zeer groote arend, die zich ophield op ('t eiland) Wapupi onder aan den zeekant. Elken dag kwam hij om menschen te vangen, en nam ze en at ze en aldus stierven alle menschen tot allen op waren, niet een bleef over dan een oude vrouw alleen met haar kleinkind. $Z_{i j}$ beiden bleven alleen over, zij verborgen zich in een kamer, en 's nachts bereidden zij eten, en bij dag verspreidden (doofden) zij 't vuur opdat 't niet zou rooken. Maar op een dag zeide de oude vrouw tot haar kleinkind: ga tot je grootvader, de oude man Wòriboi, zeg 't hem. De jongen ging en zeide: helaas! een arend moordde de negorij daarginder buiten geheel uit! De oude Wòriboi dat hoorende, nam zijn hoofd af (van den romp) en hield ' $t$ in de hand, plaatste zijne beide oogen in zijn borst, een aan de rechter hand, een aan de linkerhand, en nam zijn speer en volgde den jongen. En toen zij beiden aan 't huis gekomen waren zeide Wòriboi tot de oude vrouw: maakt beiden vuur dat 't rooke, en hijzelf steeg naar het dak, opende de katoe, en zat en loerde op 'm (n.l. den arend). Zie! de arend, de rook ziende, kwam, en kwam dicht bij de oude man, trof (hem) in de borst met de lans, en de arend stierf. De oude vrouw met haar kleinzoon liepen snel (toe) en onthoofden den arend, hakten 'm aan stukken, en verdeelden 'm overeenkomstig de ledige huizen. Toen dat klaar was riep de oude Wòriboi tot de dooden: wij gaan' wij kloppen sago! 
Maar zij antwoordden niet. Maar hij riep weer: wij roeien! wij halen sago! En in eens stonden zij op, zij juichten, zij maakten hun prauwen in orde, en zij juichten en roeiden om sago te halen. Tot dezen dag nog is 't alzoo in de negorij Windèsi: zij hebben geen sagobosschen, maar zij wenschen slechts te roeien om sago te halen, omdat zij niet hoorden naar den ouden man. Wòriboi nam den arendskop en stak dien op zijn lans, en vertrok naar zijn plaats, naar Saserkatoe, dat is hier dichtbij.

VII. Bwabwin Taburan ma bwabwin Kansinami.

Bwabwin Taburan ma bwabwin Kansinami sunmasoi na aipai rauwi na Manèwaanmirewu. Sunmasoi sunki sundaimi, ma Siriwadiòni, sunsawaanpai, sijoor rwanunumpai na bwinieempi sanu, abo sirai so rwanunumpai sanu to rawiniena, bibur so tapuni. Kausapa biò nanaria, serai $\mathrm{i}$ ja, rawiniena bibur eja so tapuni. Tapuni diutan i ja tapèna: buò bape mun pibai ? Tiòpan: ibò amana bewanam, abo imun pibai. Kausapa biò nanaria ja, sirai nanaria ja na ropai, rawiniena ja bibur eja so tapuni to warakiadirpai simasasibua, sitawa. Inèni tapuni diutan $\mathrm{i}$ nanaria: buò bape mun pibai? Tiòpan so tapuni, diòtò? ibòru, sueis jau, jawia bwabwinpai sanu. Inèni biòru, tapuni sieis, bape biòru tindia ba. Inèni bwabwin sanu sundama, sunbarirui na raanpai rami: esipai dieuso esipai, tiò : au buòne biòru pa, esipai tiòpan: jau pibai, bape au. Inèni sunderiasi to. Inèni Siriwadiòni tiòpan so tapuni: sueis seira! Bwabwinpai sunsa na atèpai, sundapon so $\mathrm{i}$, biata na anio rerabwan. Inèni esipai misoi na kasin rawanini, esipai misoi na kasin rawajana. Sunseis wòroi ba inèni tindo, riut sanu na sunbaramipaisi, inèni tiòpan so sanu: munròtò? So isěrai to imarioor pana! Jawia manupai ibòru, mundama so jau. Menau pena, sunmasoi tuter i.

\section{Vertaling.}

Vrouw Tritonschelp en vrouw Komkommer.

Vrouw Tritonschelp en vrouw Komkommer beiden zaten in den top van een boom te Manawaanmireru. $\mathrm{Zij}$ zaten te slingeren met hare beenen, en Siriwadiòni, haar beider man, zag de schaduw zijner beide vrouwen, waarop hij groef naar de beide 
schaduwen tot den avond, (toen) hij vertrok naar zijn grootmoeder. 's Morgens roeide hij weer stilletjes, en groef weer, 's avonds vertrok hij weer naar zijn grootmoeder. Zijn grootmoeder vroeg hem weer aldus: gij roeidet, maar kreegt gij niets? Hij zeide: ik roeide maar, er kwam wind zoodat ik niets ving. 's Morgens roeide hij stilletjes weer. groef stilletjes weer op dezelfde plaats, 's avonds vertrok hij weer naar zijn grootmoeder, totdat zijn nagels versleten waren en afvielen. Toen vroeg zijn grootmoeder hem zachtjes: gij roeidet, maar vingt gij niets? Hij zeide tot zijn grootmoeder: hoe zou 't? ik sterf, huil om mij, ik bedrieg de beide vrouwen. Toen stierf hij, zijn grootmoeder schreide, maar hij stierf niet werkelijk. Toen kwamen de beide vrouwen, zij twisten op weg nog, de een verweet de andere, zeggende: gij deedt hem sterven, de andere zeide: ik niet, maar gij. Toen kwamen zij dichtbij reeds. Toen zeide Siriwadiòni tot zijn grootmoeder: schrei spoedig! De beide stegen de trap op, zij gingen zien naar hem, hij lag in de middengang des huizes. Toen, de eene zat neder aan deze zijde, de andere zette zich aan gene zijde. Zij schreiden (nog) niet lang toen hij ontwaakte, hij greep haar beiden bij de handen, toen zeide hij tot haar beiden: wat zult gij beiden? Omdat ik gegraven heb was ik moede! Ik bedroog jelui beiden (dat) ik stierf, gij kwamt hier bij mij. 't Was uit, zij beiden bleven bij hem.

\section{Sinjontu Kuri.}

Sinjontu Kuri ria aduwata, babai bwinieempi sunmasoi, mièser ria so sêmàki bopai, misoi diramaan pisei. Pimuna bwa. bwinpai riama, diaan. Kuri arapai riaut pisei bwabwin. Rawiniena bibur so babai bwinieempi sanu, kausapa ria ja, to pisei bwabwin diawin pisei mònu, sinjontu wàtanpai siri, muan nina. Kausapa Kuripai ria nanari ja, sijoor pimunapai diawin, sijoor i pimunapai diawin, bibur eja so aniopai. Sasaar tindia ba, kokoripai siri siaaw, bibur ria, sia so sêmàkipai rumwaja, misoi to sasaarpai baba, inèni sijoor piseipai riama tuter pisei aantumpai sanu tuter mararia wàtan, riòsu bopaisi, kiaisi so pisei, diawi pisei abo ria wòroi katu. Pisei diaan i seira siobera ja so sêmàki rumwajapai. Riòsu bo esi, kiai $\mathrm{i}$ so wòroi. Pisei dipaira ria rusar aibo, kiripi, siobera ja so sèmàkipai rumwaja. Kuripai misoi to diru, diena na sêmàki rauwipai, piseipai bibur eja. Kau- 
sapa pisei riama ja, Kuripai riòsu sêmàki bopai ja, kiai si wòroi mò, piseipai ria rusar aibo, kiripi, siobera ja. Tapèna to diru tòru, pisei bibur eja tuter aantumpaisi, Kuripai diena ja so sêmàki rauwi. Kausapa piseipai riama nanari ja, mararia wàtanpai biba. Kuripai riòsu sêmàki bopai ja ma kiai si wòroi mò besiri, piseipai riarusar aibo wòroi, bibur aantumpai siòsa na sêmàki rumwajapai. Kuripai biaar kioor mararia wàtanpai, kioor sunbabur. Inèni pimunapai siobera siserei aantumpai, kisjo, kiri titu aipaisi, dinanaar, sieis niè marariapai, sièmua aantum pisei sanu wênasja, kioor sanu sibabur.

Kuripai kioor marariapai, kioor i so anio, sisin anio reponpai, diniwar marariapai so babai bwinieempi sanu. Inèni kausapa babai bwinieempi sanu sunronda suntara, rawiniena sunda ja ma. Kausapa sunda ja, madjawipai direr so sanu, diòjò: esi riama te nani ibaar pandòtu, munradjawa i, munda ma seira! Inèni mararia biaar pandòtu. Inèni Kuripai babai bwìnieempi sunradjawa, sundama, sunsajis, sunsajoor marariapai ma suntandoor so i, sunrutan madjawipai: muèser, i ma na? Madjawipai riaar, diòjò; inè mararia nina, bape sinjani sinjontu wàtan ba, imamaja, iporas i so manu pa!

\section{Vertaling :}

De Koèriër.

Een man van Kuri ging jagen, zijn oudere broeder en diens vrouw bleven thuis; hij alleen ging naar een idjoekboom, zitten loeren op värkens. Een zeug kwam daar eten. Die Koeriër bekende de zeug. 's Avonds vertrok hij naar zijn broeder en diens vrouw, 's morgens ging hij weer, tot de zeug ter wereld bracht: twee varkens en een echt mensch; een jongen was dat. 's Morgens ging de Koeri weer (zoo) doen, hij zag (dat) het varken had geworpen (toen) hij gezien (had) dat 't varken (had) geworpen, keerde hij weder naar huis. 't Was nog niet echt licht, één haan kraaide (nog maar), ging hij weer weg, beklom de idjoek-palm, nederzittende tot 't vol licht was. Toen zag hij 't varken komen met twee biggen en het kind; hij plukte vruchten, wierp ze naar 't varken, het varken bedriegende opdat het zich een weinig verwijdere. 't Varken at ze gauw en keerde weder tot den idjoekboom. Hij plukte andermaal vruchten, en wierp ze ver weg. Het varken liep de vruchten snel na, at ze, 
en kwam weer terug tot den idjoekboom. De Koeri zat tot 's avonds en sliep in den idjoektop, het varken keerde weer terug. 's Morgens kwam 't varken weder, de Koeri plukte weder idjoekvruchten, hij wierp ze zéér ver, 't varken liep de vruchten na, nam ze in den bek, keerde weder. Zoo gebeurde 't drie nachten (dagen, de Papoea telt de dagen bij nachten), het varken ging weer heen met de jongen, de Koeri sliep weer in den idjoektop. 's Morgens kwam 't varken en deed weer (zoo), de jongen was (nu) groot. De Koeri plukte weder idjoekvruchten, en wierp ze zéér ver weg; het varken liep de vruchten ver na, verlatende de jongen die stonden bij den idjoekboom. De Koeri daalde af, nam den jongen, nam (hem) en vertrok. Toen het beest terug kwam zocht 't den jongen, 't werd boos, beet in de boomen, schreeuwde, huilde om den jongen, 't vond de biggen slechts, nam ze beiden mee en vertrok.

De Koeri nam den jongen, bracht hem naar huis, schutte het voorhuis af, en verborg den jongen voor zijn broeder en diens vrouw. Vervolgens gingen zijn broeder en diens vrouw sago kloppen, 's avonds kwamen zij weder terug. 's Morgens gingen zij weder; de jongere broeder sprak met hen beiden af, zeggende: zoo er iemand komt zal ik de trom slaan; hoort gij dat, komt dan gauw hierheen! Vervolgens sloeg de jongen op de trom. Toen des Koeri's broeder en diens vrouw dat hoorden, kwamen zij, bestegen (het huis), zij zagen den jongen, en zij verbaasden zich over hem; zij vroegen den jongeren broeder: gij (waart) alleen, vanwaar is deze? De jongere broeder antwoordde zeggende: dit is mijn zoon, maar zijn moeder is geen echt mensch, ik schaamde mij, ik verborg hem voor ubeiden!

\section{So Jòpipaisiat sentaan wamar ba.}

Jòpipaisiat senmasoi papon na Batéwaar. Senberim senbò so Waropan sentadu. Saroi tioon siat tuter wapai kòta. tioon siat na rawanam rabwan, ria tuter siat na rawanam djowab. Senmasoi na diaan sanèpai senkutu diaan niè ateenpai sanèwạipaisi, sentarasabu wapai, senduri adia na dinie, sentinunum sanèpaisi, sentaan si. Senkutui diaanpai, biòru, tiupar, diwarira are, sindem. Sinjontusi senna na diaan sanépai sentadjawa wamar tikaan, sentòjò: re pi na te? Senderai diaan sòrèpai, sensajoor repai ma sensubi. 
Inèni wamarpai riama tiòpan so siat, diòjò : jau! inanari mi at mentenam! Inèni menda re, menkoor mennèpaisiat, menmasoi na nu nè. Inèni sentarien senda rau. So nini Jòpipaisiat sentaan wamar ba.

\section{Vertaling.}

Waarom de bewoners van het eiland Jop geen jaarvogels eten.

De Jopers woonden vroeger te Batèwaar. Vijf hunner roeiden naar Waropen om sago te halen. Een walvisch slokte hen in en hun prauw ook, midden in zee, zij ging met hen naar de diepte der zee. Zij die zaten in den buik van den visch, sneden lever (en) darmen van den visch stuk, hakten de prauw stuk, legden vuur aan op den prauwhaard, poften den buik (ingewanden) (en) zij aten ze. (Daar) zij den visch stuk sneden, stierf (deze), dreef boven en landwaarts tot zij strandde. De mannen zittende in des visschen buik hoorden een jaarvogel roepen; zij zeiden: is dat land? $\mathrm{Zij}$ openden den bek van den visch, zij zagen het land en zij gingen naar buiten.

Toen kwam een jaarvogel zeggende tot hen; zeggende: ik (deed 't): 't is mijn werk dat gijlieden leeft! Gaat nu landwaarts, haalt de uwen, en verblijft op dat eiland. Toen verhuisden zij gaande zeewaarts. Daarom eten de Jopers geen jaarvogel.

X. So Padewaisi sendutawan amurpai.

Kutuwarai, baba Padewai esi, biòsê dirariaar na Wasaanbin. Miun diaanpai tòru, kioor si are tiòta si. Tiòta diaanpaisi to kiutu sasara warakiapai, biòru biata na Wasaanbin. Sinapaisi sibata na kembêre katupai tuter aiku sarfeer. Amur asiwandami. Amurpai bie ajorikai. Bebòrupai tiòpan papon maso Padewai bemasoipaisiat: mendutawan amur nè, menmun pi tapè jau! Padewaisi sendutawan amurpai to raria nini, senmun pi tawana, senmênau ba.

\section{Vertaling.}

Waarom de Padewai'ers vasthouden aan het schildpadnet.

Kutuwarai, voorvader der Padewaiërs roeide (om) met het net te visschen te Wasaanbien. Hij ving drie visschen, bracht 
ze naar land, en sneed ze in stukken. Hij hakte de visschen in stukken tot hij mis sneed in zijn vinger, hij stierf, en ligt te Wasaanbien. De beenderen liggen in een klein gat (hol) met de vischlijnrol. Het net is er nog. Het net werd waringinluchtwortels. De gestorvene had tevoren gezegd tot de Padewaiërs die thuis bleven: houdt $\mathrm{u}$ aan dit (soort) net, vischt zoo als ik! De Padawaiërs houden vast aan dat net, zij visschen er dagelijks mede, zij eindigen niet.

\section{Bwisaar niè a ntumtapubwabwin.}

Anina bwisaar siri tuter tapubwabwin siri, sunmasoi na wis, ma bepaupaisiat senmasoi na sasipai, ma rabwan siat anina kòta anio siri. Ma raria siri bena sasipai siat sendoi. Ma bwabwinkatu na bwisaar nini tiòpan maso tapuni diòjò : isanèwèsjeen ira abo imaji, bape nani jau tanè? Tapuni tiòpan so $\mathrm{i}$ : asisi au! nani isaserei pisiri maso au. Inèni tapuni ria ma kioor nandaukòpipai, ma kiaak $i$, ma ria ma ribu kabui kòta maso i, ma diòně dibabaar tapè muan. Ma rawiniena ria so anio jana, sijoor katim siri misoi, ma siaaw i, tiòpan: manèta! wama! tunda tunmaji! Ma katim nini riaar so $\mathrm{i}$ : jo! imarandin jani. Ma katim nini mirandin to sunda. Ma rispai mimasaar, bwabwinkatu nini kijajera $\mathrm{i}$, diòjò: mònowor muan mònowor bwabwin sunê rawabo diru nini, ma sunraran to sasaar! Ma senmaji to, sentaanpi pena, bwabwin-katu arapai bibur so anio reponpai abo sensajoor ririn i pênai. Ma sentaanpi to, katim arapai siaaw i diòjò: manèta! wama! tantaanpi. Bape riaar i, diòjò: mentaanpi sarêdjeu, so jomara beja, imasoi nanina abo jomara to mènau. Ma sentaanpi to mènau katim arapai siaaw bwabwinkatu: jò! manèta! wama tunda rau tunmaji. Ma senmaji to rispai mimasaar, bwabwinkatupai arapai kijajera i, tiòpan: mònowor muan mònowor bwabwin sunè rawabo diru nini, ma sunraran to sasaar! Ma senmaji to deriasi sasaar pena, bwabwinkatu tiòpan so katimpai: manèta! tunbabur so tunnè utanpai wòroi, tunda abo tunrena. Ma sunbiaar, sunda, ma sunda to raanpai rabwan, bwabwinkatu tiòpan so katimpai : manèta! muajar ma tunda tunmasoi tunraanpi na apusi nia wa! Ma katim tiòpan: jò! itòpan so awini papon. Ma tiòpan so sinjani, diò: awini! manèta diòjò: amunda so tapuni nia wa! Ma sunda sunmasoi to rawiniena, ma katim tiòpan so i: manèta! jò! ira isajoor inè pimarandin wa si, abo tunda ja 
tunmaji. Ma ria ma diru pena sunda ja sunmaji, ma senmaji diru tòru, ma kausapa sunbabur eja so sunnè anio. Ma bwabwinkatu tiòpan so katim: manèta! muajar tunda, tunmasoi na apusi nia wa, tunmasoi tunrena dirupèsasi. Ma katim tiòpan: wèsjeen! nani tunda! Ma sunda, ma katim misoi tuter bwabwinkatu tapuni sanu. Ma diru sentena pena, bwabwinkatu tiòpan so katim: manèta! rua, buena papon. Ma katim ria diena. Ma dienasiat besiri. Inèni bwabwinkatu ria riuran niè pimarandinpaisi, ma dibabaar niè sis kariesi, ma diur niè sampaarpaisi. Inèni siuwa ma diena tuter katim nini. Ma sunrena to diru rabwan, katim diena to kiai wara, ma warapai biata babo sis kariësipai na bwabwinkatu, ma tindo, tiòpan: teï nini? arapai ina te? irin ba! diawi jau te? Ma diena ja to sasaar, inèni sijocr bwabwin nina ma tindoor, bape sunrena wura to, ma sunririoot to, ma bemònu sunrena ja. Ma tapuni tiòpan so bwabwinkatupai; munrena, ma nani budjawa pi esasi siraròtu, kubio pênai, bape buena sisi. Ma na diru rabwan raarpaisi sisa na kemberepai so babo, ma siraròtu. Ma bwabwinkatu tiòpan: witoi siraròtu pa? Ma besiri raarpaisi si měnau. Ma tapuni tiòpan so i: itòpan to: kubio pênai! bape budjawa ba. Ma tapèna senmasoi sembiai tòru.

Inèni sawani tiòpan so bwinieempi: muajar! tunda so awinisiat, nani sentanòta jau to wòroi to. Ma bwinieempi tiòpan: wèsjeen! tunda! Ma sunda pena, tapuni tiòpan so i: munda, ma raria siri sujoor kamajopai tipu babo wis nini ruin ibòru to, ma ruama kuoor raar nèsi. Ma tapuni diòne kòta so i niè rawabwisaar kariria besiri, runandau ritapapatin, rèbibar, dirè sitawa kariria besiri. Tapèna to sunda rau. Ma katim nièpaisiat sensajoor i sentandoor, ma senkemberei i, senkanisu so i, ma sentatar i, misoi na djo, senmajar ba sia so anio. Bape raarwo katupai sanêpai i, riama misoi tuter i. Ma nianari jaba katu maso i, ma sunmasoi na i. Ma raria siri senbò senberait, ma sawani kòta diot siat. Ma diru siri bwabwin tuter diròbwabwin sunrena, tiòpan so diròbwabwin katupai: buena, ma nani tunradjeu ma ai sjawa na surawapèsi, tundo pěnai buena sisi. Ma sunrena to, kausapa suntando, sajoor! anio pimasa to, diòsa rabwan sanu. Ma sunmasoi na i. Ma raria siri sentadjawa taburan siròtu, ma sensanèwèsjeen baba, senmaji bedjoor siat, sanu kòta sunmarandin sunrura sunnè sampaar baba pau besiri. Ma diròbwabwin baba sensaaw na sanu, bape bwabwinkatu miajarê si ba. 
Bwabwinkatu sawani sanu sunmasoi na anio toraupai. Sunmasoi to bwinieempi sijoor kamajo sitipu na wisêpai, tiòpan so sawani: apusi biòru to, kamajopai sitipu na wisêpai! Tanda! tantarien pigàngènam. Inèni senda sentarien pigàngènampaisi wura. Nini měnau senmasoi wura na dorau.

\section{Vertaling.}

Grootmoeders dochter.

Er was een oude vrouw met een kleindochter, die woonden op een berg, en zeer velen woonden aan 't strand, en tusschen hen in was ook een huis. En op een dag zouden zij die aan 't strand woonden zingen. Het meisje van die oude vrouw sprak tot haar grootmoeder, zeggende: ik zou gaarne gaan om te dansen maar hoe zal ik? De grootmoeder zeide tot haar: houd je maar stil! ik zal iets zoeken voor je! Toen, ging de grootmoeder en haalde een uitgebloeide pisangbloemkolf, en schilde die, ${ }^{1}$ en ging en pelde ook een schaamgordel voor haar, en liet haar zich gorden als een man. En 's avonds ging zij naar het huis daar (dat wat stond tusschen den berg en 't strand), zij zag een jongeling zitten en riep hem, zeggende: vriend! Kom! wij gaan dansen! En de jongeling antwoordde haar: ja! ik versier me aldus! En als de jongeling zich versierd had gingen zij beiden. En de feestgenooten schreeuwden en lachten, en dat meisje riep: langstaartduif doffer en langstaartduif gaaike, zij blijven samen dezen nacht, zij blijven wakker tot 't licht! Toen zij gedanst hadden, en eten gingen, ging dat meisje naar de voorzijde van het huis (de plaats der mannen) opdat men haar niet zou herkennen. En toen er gegeten werd riep die jongeling haar zeggende: vriend! Kom hier! laten wij eten! Maar zij antwoordde hem zeggende: eet maar! ik ben te warm, ik blijf hier opdat mijn warmte over ga! En toen zij gegeten hadden riep die jongeling het meisje: ja! vriend! kom wij gaan naar voren, wij dansen! En men danste tot de feestgenooten juichten; dat meisje riep ook zeggende: langstaartduifdoffer en langstaartduifgaaike zij blijven samen

1 Bedoeld wordt: in den vorm van mannelijke genetalia, zoodat het meisje voor een jongen zou worden aangezien. 
dezen nacht zij blijven wakker tot het licht! En zij dansten tot nabij het licht (dageraad). Toen zeide het meisje tot den jongeling: vriend! laten wij heengaan naar ons verre land (of: plaats), laten wij gaan slapen. En zij daalden'af (n.l. uit de paalwoning), en liepen tot halverwege. Het meisje zeide tot den jongeling: indien ge wilt, dan gaan wij wat zitten eten bij grootmoeder die dáár woont. En de jongeling zeide: ja! ik zeg het eerst aan moeder. En hij sprak tot zijn moeder, zeggende: moeder! (mijn) vriend zegt: gaan wij samen naar zijn grootmoeder die dáár woont. En zij gingen en zaten tot den avond, en de jongeling zeide tot haar: vriend! ja! ik ga mijn versierselen nazien daar! opdat wij weer gaan dansen. En hij ging, en 's nachts gingen zij beiden weer dansen, en zij dansten drie nachten, en 's morgens gingen zij weer weg naar hun huis. En het meisje zeide tot den jongeling: vriend! wilt gij dan gaan? wij blijven bij grootmoeder die dáár woont; wij blijven daar eenige nachten slapen. En de jongeling zeide: goed, wij zullen gaan! En zij gingen en de jongeling bleef met het meisje samen bij grootmoeder. En 's nachts toen zij slapen zouden zeide het meisje tot den jongeling: vriend! ga gij eerst slapen. En de jongeling ging slapen. En hij sliep zeer vast. Toen ging het meisje hare versierselen verzamelen, en gorde zich met haar (met) schelpen (versierde) schaamtegordel, en deed haar schelpen ringen aan. Toen ging zij naar binnen en sliep met dien jongeling. En zij beiden sliepen tot middernacht, de jongeling sliep tot hij zijn hand uitsloeg, en zijn hand legde op den (met) schelpjes (versierde) schaamtegordel van 't meisje, en hij wakker werd, zeggende: wie is dat? is diegene het? ik weet niet (of) hij mij beliegt? En hij sliep weer tot het licht, toen zag hij die vrouw en schrok, maar zij hadden al samen geslapen, en zij waren al gehuwd, en ten tweeden male sliepen zij weer. En de grootmoeder zeide tot het meisje: slaapt jelui beiden, en als gij hoort iets dat geluid maakt, spreekt niet, maar slaapt stil. En te middernacht stegen goederen op uit het gat (dat in een paalwoning voor closet etc. dienst doet) naar boven, en zij gaven geluid. En het meisje zeide: wat maakt daar geluid? En in eens hielden de goederen op. En de grootmoeder zeide tot haar: ik zeide al: praat niet! maar gij hoordet niet! Toen bleven zij drie manen (maanden).

Daarna zeide de echtgenoot tot zijn vrouw: wilt ge, dan 
gaan wij naar moeder en de haren, zij wachten mij reeds lang. En de echtgenoote zeide: goed! laten wij gaan! En toen zij gaan zouden zeide haar grootmoeder tot haar: jelui gaan, maar op een dag, (als) gij ziet dat witte dampwolken zich verheffen (uitbreiden) boven op dezen berg, weet (dan) dat ik dood ben, en kom, haalt mijne goederen. En de grootmoeder gaf ook aan haar haar oude vrouwen huid (die) zeer slecht (was), haar vanzelf uitgevallen haren, haar oogslijm en haar uitgevallen tanden, zeer slechte. Aldus gingen zij zeewaarts. En toen des jongelings huisgenooten hem zagen schrokken (ontstelden) zij en haatten hem, spogen naar hem, en joegen hem (dat) hij beneden bleef, zij wilden niet dat hij in huis steeg. Maar een kleine zuster beminde hem, zij kwam (en) bleef bij hem. En zij maakte een kleine hut voor hem, en zij woonden daarin. En op een dag roeide men uit op raak, en de echtgenoot roeide met hen. En op een nacht sliep de vrouw met haar schoonzuster samen, en zeide zij tot hare kleine schoonzuster: (als) gij slaapt en wij (de beenen) uitstrekken, en de voet hangt aan (of steunt tegen) de boomschorswand, word niet wakker, slaap stil! En toen zij geslapen hadden, ontwaakten zij 's morgens en, zie! een reeds groot huis stond tusschen haar beiden! En zij woonden er in. En op een dag hoorde men de triton-(oorlogs) schelp' blazen, en zij verblijdden zich zeer, zij (gingen) dansende hen inhalen, zij beiden versierden zich ook, zij deden hare zeer vele groote schelpen armbanden aan. En de groote schoonzusters vroegen aan haar beiden (om armbanden), maar het meisje wilde ze niet (geven).

Het meisje en haar man, zij beiden woonden in het zeewaarts staande huis. $\mathrm{Zij}$ woonden daar tot de echtgenoote zag de witte dampwolken zich uitbreiden op den berg, en zij zeide tot haar man: grootmoeder is dood, de witte dampwolken breiden zich uit op den berg! Laten wij gaan! laten wij de bezittingen overbrengen. Toen gingen zij al de goederen halen. (Toen) dat klaar (was) woonden zij allen aan den zeekant.

XII. Sinjontu ria moja ha niê a antumbwabwin.

Mambesawa sanu tuter tamaani senmasoi na anio siri. Senmasoi to raria siri sawani tiòpan maso bwinieempi: tamamu 
munmasoi, ibò imun diaan so tatat. Biò to, bibur mare, siaaw bwinieempi: isòpi! ruama kuoor diaan nèsi, buinunum pi tamamu tantaan. Niunum si to simasa, siaaw sawani: wama! kuoor anamnèsi tuter diaansi, niòmui munraansi '. Sawani ria kioor si, bape diaan siparèsi berusuwa niòni. Sikeito sië anampapipaisi to, biubu diaan karu so anampapipaisi, biubu i so niòni niè rupai. Menau siaaw bwinieempi: isòpi! kuoor winioinè, tamamu, amunraan si to keito. Bwinieempi kioor winioipai rioram i. Kausapa ja tiòpan eja: tamamu mumasoi, ibò ja imun pi tatitaanpi. Ma biòs eja, rairu bibur, ma siaaw bwinieempi ja: isòpi! ruama kuoor diaan nèsi, buinunum pi tamamu tantaan. Niunum si to simasa, siaaw sawani, ria kioor si ja, bape diaan sipar berusuwa niòni ja, sië anampapipaisi ja, biubu diaan karupai swa si: ma biubu so niòni niè rupai eja. Tapèna nianari raria wura ja. Bwabwinpai tamaani misoi to babisi miun i, siòsar niè sanaipai tiër sèbèriani, siabu $i$, niè rawesi, niè wona katu niè rawesi, Raria wura nianari so niòni tapèna, niòni tiër tawana sèbèriani, diaan wora, aantumbwabwin rin $\mathrm{i}$ ba, tamaani tiòpan so aantumbwabwinpai ba. Diniwar i to raria siri sawani bios eja, tamaani siaaw aantumbwabwinpai: isòpi! Wama kuoor inè rutu nèsi! Aantumbwabwinpai riama sijoor tamaani niè rupai bië gangụnam beja, niè tèraipai siei kariria besiri. Aantumbwabwinpai diutan tamaani: buòtò? Tamaani tiòpan : jòtò! bape sawamu diaan pisjaanpaisi berusuwa jau, biubu karupaisi so runè wora. Inèni aantumbwabwinpai kisjo, nianari karumaas, disoïb tamaani to tamaani teraipai pia ja, niunum pi so tamaani, kioor si so tamaani diaan si. Diaan to keis tiòpan so tamaani: jai! nani tunbabur so toi? Tamaani tiòpan so aantumbwabwinpai: tunbabur tunnai na sweb. Inèni aantumbwabwinpai biai tamaani so tamani ria moja ba, aipaisi sikapau. Inèni siobera kioor tamaan sunnè kainampaisi, kioor si to si keis, siobera rau so aniopai, kioor sawani niè kababòpaisi, kioor $\mathrm{si}$, disan si na atèpai bwabwapai, inèni titòpar atèpai bwabwapai, Inèni kioor sawani niè atoborapai diana tatir aniopai, diawi sawanipai, aborè bibur diniwar, diòsa diduaat sawani. Inèni sawani bibur ma, sijoor atopaisi si ter na aniopai, dipai to sia na anioreponpai, sisera bwinieempi tamaani sanu, bape sunna ba, dipai apui, tiò biaar na atèpai, atèpai diòtu tuter $\mathrm{i}$ awaab,

${ }^{1}$ De vrouwen bereiden de spijzen voor de mannen, maar eten niet met hen. 
kababòpai esi disan na warababa rawesi, esipai disan warababa rawesi, bioru. Bwinieempi dipai arau, miji kainam so i, diòjò: buaan pi berusuwa jai jě, bubu karu so i pena! jò! ibaitê pena, Bibur are, tiòpan so tamaani: diòtò? jai jě! arapai imun i to . biòru to! Inèni sunrena na swebipai to aantumbwabwinpai diutan tamaani: jai! nani tunda tunnai na toi? Tamaani tiòpan: buai jau kuoor jau aji. sujoor wis katu, jana puir jau na, nani tunmasoi na jana! Ma bwabwin kioor tamaani, pir i to, siobera ja diriën sunnè pigangènam ma. Inèni misoi to rawiniëna tamaani kiaas $i$, pir ariri sunnè aniopai. Ma rawiniëna tiòpan so aantumbwabwin: diru tunrena to budjeus siawa piësi, kubio pènai, buena asisi. Ma sunrena to aantumbwabwin didjeus siawa airawa bape kibio ba. Ma sunrena to kausapa suntandoor sijoor sunnè anio. Ma inèni sunraan sunnè diaanpai si keis, aantumbwabwinpai tiòpan so tamaani: jai! musoiriaat tunnè anionè ma ira itapur kaween maso tanu tunritaanpi. Ma ria, ria tipur to rawiniëna, biburè $m a$, niunum pi tamaan sunraan i. Kausapa tiòpan eja: jai! musoi tuter tunnè anio, ira itapur eja. Ma ria ja to rawiniëna bibur eja, niunum sunritaanpi ja. Raria wura tiòpan tapèna, ma nianari tapèna. Raria siri tiòpan so tamaani: jai! inunum taun pau maso au, so ira so wòroi, itapur na kambo be wesje. Ma ria sièmua mambebaba senbetòru sentaweer. Senmum pisei siri, senkoor aiwadupaisi tuter warapai sanu, ma senkai ru, sanèbaba, sinapaisi bena karusina, senkaiési sibata na mariapai, senbaburé si, Bwabwin tipur diaan sièmua si ma kioor si are, siobina si na sennè roipai to miasa, kioor si, bibura so tamaani, bape tiòpan so tamaani ba, diniwarësi, ma niunum pi na kaweenpaisi so tamaani. Sunrena to kausapa, tiòpan eja: jai! musoi! ira ja! Ma ria ja, sièmua mambabasiat ja, ma senmun pimuna siri ja, senmasoi sentòtai $i$, senkoor těraipaisi, sensobina si, senkai sinasi na arau so kambopai eja. Ma bwabwinpai diòsa na airumwaja, diduaat siat. Ma sennè wonapai rira $\mathrm{i}$ ma siòsar $\mathrm{i}$. Ma babai dimis niè madjawi: rua sujoor witoi wona wani siòsar $\mathrm{i}$ wa. Ma ria re bape bwabwin diniwar ma rin $\mathrm{i} b \mathrm{~b}$, ria rau, tiòpan so babai: irin i ba witoi siòsar i. Ma bwabwin titira ja rau, ma wonapai sijoor i ja, siòsar i ja, Ma babai dimis madjawirabwanpai, ma ria re inèni sijoor bwabwin, ma tiòpan $\mathrm{i}$ so babai: babaia! inèwi te? Ma babai tiòpan: witoi nina? Ma madjawi tiòpan: witoi! bape bwabwin nina! Bwabwin nini diteen tòrò! Ma 
babai tiòpan: au bemadjawi, jau babani jau! jau inèwi. Ma madjawi tiòpan: mojar! jainèwi! abe suaaw $\mathrm{i}$ be rewa! Ma babai tiòpan: mojar! jainèwi! abe suaaw i be sinja. Ma babai nièwi, nini senkoor $i$, senbabura so sennè anio. Ma sendaarwobwabwinpai siat sensajoor i sentòpan: tuòpi siat senkoor bwabwin nini na toi? Ma sensaji so anio, ma sensanèwèsjeen to baba, sentòne so $\mathrm{i}$ àdiararië pau besiri sentòpan diaan si. Bape tiòpan: amanpa amantaan nina si ba! Diaanpiba raria mònu diru mònu. $\mathrm{Ma}$ sentòpan so $\mathrm{i}$ : amat, amannè pisjaan, amantaanpai anina to! Ma bwabwin sijoor anam pau siòsa warir aniopai. Bwabwinpai diutan sawani, tiòpan: pininasi mentòne si tanè? Sawani riare so i: sitera saredjen. Ma bwabwinpai tiòpan so sàwani: amannè pi amantaanpasi na! Siaaw tamaan na sawani, ria ma kioor amau, kioor si ma nianari si to sikeis. ria kioor tamaanpai, ria diraar anampai rabo siri, diraar $\mathrm{i}$ to, dirobwabwinpai siat sentananaar: Kababò! Kababò! Ma bwabwinpai didjawa siat ba, ma rioban i to tiawa, riapon, kiaak sabapaisi. Inèni kioor si arau, nianari si na kambodirèpai. Inèni ria re, siabu anampai, ma misoi tiara waradiri, tiara to beinam, pisaan si, kioor si arau, riamu si to si keis, si joor anam têrai, kioor si aji so aniopai, diòne karumaas diòtêra, nini disin anampaisi, misoi diaan si. Ma dirobwabwinpai siat sentòpan: buaan si sièteen te? Ma dirobwabwinpai tiopan: sièteen bai? amat ma pisjaan amantaanpai nina. Ma sensaaw diaum siat kòta. Bape diaum siat sentaan si apui senmamuta adiarariëpaisi so anampaisi siriata sensanempaisi. Raria wura tiara diaum siat tuter anam, to senmamuta mênau, senmamuta adiararië to keis, inèni senmamuta to mênau. Inèni senmasoi to bwabwinpai diawin. Ma marariapai misi biba, inèni sinjani tiòpan so sawani: tanda, tansajoor jai! Ma sawani tiòpan: tamamu misoi na? Ma bwinieempi tiòpan: misoi na amannè aniopai, irin ba biòru to te. Ma sawani kisjo i, tiópan: buòtò? tuòpan $\mathrm{i}$ ba tanda tankoor ibai? puoras i so? Ma inêni senda. Ma bwinieempi tiòpan: nani tankoor jai tanè? Ma sawani tiòpan: diòtò? Bapa bwinieempi tiòtò: ria-moja-ba, kipau! Senda sawani siserei airawi, ma kioor si, sisa si na sasapai. Ma senda so tamaani na aniopai. Bape tamaani diaan niè pisjaan to sikeis, ma babisi miun $\mathrm{i}$ to katu biòru, ria pui sirai mitauni na wabupai ma biata. Ma aantumbwabwinpai siaji, ria sisêrei i, ria pui, si joor i biata na wabupai. Ma dikai i ja, kioor tamaan' mare berusuwa Dl. 70 
wabupai, ma kioor i apon, kioor kambo ma sioibi rurạ̣ wabupaisi berusuwa $i$. Inèni niunum pi so $i$, diaan to miòsi. Ma nebwiniabipai dimis $\mathbf{i}$, dikai aji, riut $\mathrm{i}$ na aimarabopaisi, dibakir. Ma nebwiniabipai siraab niòni niè aipaisi bape sikabit, Ma siaaw bwinieempi kioor rèru, ma kioor rèru maso sawani, ma sawani dikutu niòni aikarandopaisi, ma inèni biubu airawi so kaporpaisi. Ma inèni pia ria, niòni sanèwèsjeen. Niòni tiòpan so nebwiniabipai: ande! pi pa nina wèsjeen beja! Jo! inèbwiniabi bepapon tapèna rèto! bape $\mathrm{i}$ kiriria, dinakai so jau, ma inè nebwiniabi bepui i ma diteen! Ma bwinieempi tiòpan so sawani: tanbabur te? Ma tamaani tiòpan: tanmasoi na nina, nani tandoi papon, keis, menda. Ma inèni senda sentariën anampaisi maso aniopai. Ma inèni sendoi. Sendoi to diru rabwan, kawàsa pau sensa aniopai to aniopai kiòtar. Ma nebwiniabi siaaw: mennunum pi so risê nè! bape niòni tiòpan: mojar! nani katuesê ni. Ma diru rabwan pisjaanpai sia na kamaripai ma ji to aniopai kiòtar. Inèni risêpai diaan $i$, sentaan to senpa ba. Mararia siri tiòpan: jaan to, ikamberei to! Besiri pisjaan mênau. Ma kawàsa sentòpan: tanè tuòpan tapè nina? inèni pisjaanpai bibur tatat, nani tantaanpi ba, tanbabisi. Ma inèni mênau niòni tiòpan senbabur. Bape nebwiniabi tiòpan: tanmasoi sarêdjeu na nina!

\section{Vertaling:}

De kreupele en zijn dochter.

Een echtpaar met den vader woonden in een huis. Op een dag zeide de echtgenoot tot zijne vrouw: uw vader en gij blijven hier, ik roei, ik ga visch vangen voor ons. Toen hij geroeid had en landwaarts kwam, riep hij zijn vrouw: isòpi kom hier, neem deze visschen, kook eten voor je vader (en) ons. Toen zij ze gaar gekookt had, riep zij haar man: kom hier! neem de sagopap en visschen, uw schoonvader en gij eet ze. De man nam ze, maar at alles op (ook dat) van zijn schoonvader. Toen het op was, schrapte hij de overblijfsels bijeen, goot het vischnat op het afschraapsel, en stortte het op zijns schoonvaders hoofd, daarna riep hij zijne vrouw: haal de etensbak, uw vader en ik aten alles op! De echtgenoote haalde de etensbak en wiesch die. Den volgenden morgen zeide hij weder: je vader en gij blijven hier, ik roei weder en vang wat te eten. Hij roeide 
weer, en met den vloed vertrok hij weder (naar huis) ' en riep zijne vrouw weder; insòpi! kom hier, neem deze visschen, kook eten, (opdat) uw vader en ik eten. Toen het gaar was, riep zij haar man, die haalde het weder, maar hij at het alles voor zijn vader weg, schrapte de sagoaanhangsels weer bijeen: goot het vischnat er bij, en stortte het weder over zijns schoonvaders hoofd. Zoo deed hij alle dagen weder. De vrouws vader zat tot de honger hem kwelde, stak met zijn speer een papajavrucht af, sneed die door, een deel voor hem, een deel voor zijn kleine hond. Alle dagen deed hij aan zijn schoonvader aldus; de schoonvader stak dagelijks een papaja, at voordurend (alzoo). Zijn dochter wist dat niet, de vader zeide niets tot zijn dochter. Hij verborg het tot op een dag de echtgenoot weder roeide. De vader riep zijn dochter: isopi kom hier! neem mijne luizen weg (d.w.z. reinig mijn hoofd van luizen). De dochter kwam (en) zag het hoofd haar vaders vol maden, zijn lichaam stonk erg, De dochter vroeg haar vader: wat scheelt u? De vader zeide: wat me scheelt? maar nw man eet al het eten voor mij op, en stort voordurend het nat over mijn hoofd. Daarop werd de dochter boos, zij maakte warm water, spoelde haar vader af tot haars vaders lichaam weer sterk was; zij kookte eten voor haar vader, bracht het tot haar vader die het at. Toen hij het opgegeten had, zeide zij tot haar vader: vader! waar zullen wij heengaan? De vader zeide tot zijn dochter: wij vertrekken samen (en) gaan wonen in een grot. Vervolgens droeg de dochter haar vader (op den rug) want haar vader kon niet loopen, zijn beenen waren krom. Daarna keerde zij terug en haalde haars vaders en hare goederen, haalde alles weg, keerde naar buiten terug, nam de pijlen met roggestekelspunten van haar man, nam ze en stak ze onder de (huis) trap (nat. met de punten naar boven), vervolgens hakte zij den trap ${ }^{2}$ aan den onderkant bijna door. Vervolgens nam zij haars man pijlenbos en schoot (pijlden) er mede op het huis, bedriegende haar man. Toen ging ze zich verstoppen, en stond te loeren (op) haar man. Vervolgens keerde haar man terug, hij zag de pijlen in het huis steken, liep hard tot hij in het voorhuis klom; hij zocht zijn vrouw en vader beide, maar zij waren er niet. Nu liep hij (naar)

1 De Papoea vischt bij laag water op de banken en riffen. Als de vloed opkomt, keert hij huiswaarts.

2 Een ingekeepte boomstam dient als trap voor de paalwoning. 
't achterhuis, wilde de trap afdalen, (doch) de trap brak onder hem; één roggestekelpunt-pijl stak hem in den eenen oksel, een andere in den anderen oksel, (zóó dat) hij stierf. Zijne vrouw liep (nu) naar buiten, schoffelde (met de voeten) vuilnis op hem, zeggende: gij at alles voor mijn vader op, en begoot hem met het nat, ja! ik betaal je! $\mathrm{Zij}$ ging landwaarts, en zeide tot haar vader: wat wil hij nu? Vader! die daar! ik doodde hem, hij is dood. Vervolgens verbleven zij samen in de grot tot de dochter haar vader vroeg: vader! waarheen zullen wij gaan wonen? De vader zeide: draag mij (op den rug), breng mij naar boven, zie dien kleinen berg, daar zet gij mij neer, daar zullen wij wonen! De vrouw bracht haar vader, (en) hem neergezet hebbende, keerde zij weer terug, bracht hun beider bezittingen over. Vervolgens zaten zij tot, tegen den avond, de vader zich schoof (schuivende zich verplaatste) (houtjes) uitleggende overeenkomstig hun beider huis, (het oude huis op die plaats teekenen of aanwijzen). En 's avonds zeide hij tot zijn dochter: van nacht als wij slapen, (en) gij uw voeten uitstrekkende die ergens tegen laat steunen, praat dan niet, slaap stil. En toen zij sliepen en zij haar voeten uitstrekte, steunde die aan een boomtak, maar sprak niet. En zij sliepen tot den morgen en zij verbaasden zich, ziende hun huis. En daarna bleven zij tot zij al hun eten hadden opgegeten, (toen) zeide de dochter tot haar vader: vader! pas gij op ons huis, en ik ga garnalen voor ons vangen om te eten. En zij ging, zij ging tot den avond, keerde terug; kookte eten, en haar vader en zij aten het. 's Morgens zeide zij weder: vader! gij blijft in ons huis, ik ga weder op de vangst. En zij ging weer en keerde 's avonds weder, kookte hun eten weder. Alle dagen zeide zij zoo en deed alzoo. Zekeren dag zeide zij tot haar vader: vader! ik bak veel sago voor $\mathrm{u}$, want $\mathrm{ik}$ ga ver weg, ik vang (visch) in een andere rivier. En zij ging en zij vond drie gebroeders op jacht met honden. Zij (hadden) een varken gedood, zij namen de hammen met de beide voorpooten, en zij wierpen weg den kop, den onderbuik en de botten van de ruggegraat. $Z$ ij wierpen ze weg in het water, zij lieten ze daar. De vrouw visch vangende vond ze en nam ze aan land, rookte ze op hun (der mannen) rookrek tot ze klaar waren, nam ze, ging weg naar haar vader, maar zeide het niet tot haar vader, verstopte ze, en kookte eten van de garnalen voor haar vader. $Z$ ij sliepen tot 's morgens 
en zij zeide weer: vader! blijf ik ga weer. $Z$ ij ging weer en vond de gebroeders weer, die hadden een beest gedood. Zij zaten het af te hakken, namen de vleeschstukken, rookten die, wierpen de botten weder naar buiten in het water. En de vrouw stond bij een boomstam hen beloerende. Hun hond rook haar en blafte haar aan. En de oudste beval zijn jongsten broer: ga zien wat de hond daar aanblaft. En hij ging landwaarts, doch de vrouw verstopte zich en hij bemerkte haar niet. Hij ging naar buiten zeggende tot zijn oudsten broer: ik weet niet wat hij aanblafte. De vrouw zag weer toe, en de hond zag haar weer en blafte haar weer aan. En de oudste broer zond den middelsten broer, en hij ingaande zag toen de vrouw en zeide tot zijn oudsten broer: broeder! bezit ik haar? En de oudste zeide: wat is er? En de jongere zeide: wat! maar het is een vrouw! Deze vrouw is bijzonder schoon! En de oudste zeide: gij zijt de jongere, ik, ik ben de oudste! ik bezit haar. En de jongere zeide: dat niet! ik bezit haar! daarom noem haar uw schoonzuster! En de oudste zeide: dat niet! ik bezit haar! daarom noem haar moeder. En de oudste had haar, dus namen zij haar mede, zij gingen heen tot hun huis. En hunne gezusters haar ziende zeiden: waar halen de toewoppi's deze vrouw van daan? En zij stegen in 't huis, en verblijdden zich zeer; zij gaven haar zeer veel houtskool, zeggende dat zij dat eten zou. Maar zij zeide: wijlieden eten dat niet! $\mathrm{Zij}$ at niet twee dagen en twee nachten. En zij zeiden tot haar: ons (aangaande) (dit is) ons eten, onze spijs is dit! En de vrouw zag veel sagoboomen rondom het huis. De vrouw vroeg haar man: deze hier, wat doet gij daarmede? De echtgenoot antwoordde haar: die staan daar maar zoo. En de vrouw zeide tot haar man: dat is ons eten. $\mathrm{Zij}$ vroeg een bijl aan haar man, zij ging en haalde (hout waar) sagokloppers (van gemaakt worden), zij nam ze en makkte ze klaar; zij ging de bijl halen en ging een sagoboom schoonmaken. Bij het schoonmaken riepen de schoonzusters: roggestaart-punten! roggestaart-punten! (bedoeld worden de groote dorens die aan den sagopalm zitten; de vrouwen zagen ze daarvoor aan en hun roepen was bedoeld als waarschuwing). En de vrouw hoorde niet naar haar, maar velde den boom tot hij viel, ging naar het boveneinde (en) pelde de (aan 't stameinde $\pm \frac{3}{4}$ Meter breede) bladsteel-stam-einden los. Vervolgens nam zij die, en maakte ze (door ze op in den grond gestoken 
van boven kruiselings gebonden stokken te leggen tot sagowaschbakken) aan den rivierkant. Vervolgens ging zij terug, kloofde den stam, en zat te kloppen aan het topeinde, klopte het tot sagoklopsel, deed 't in een zak, bracht 't uit, kneedde 't (met water) tot 't op was. (n.l. de sago uit de hout-vezels), bezag het sagomeel, nam het naar boven in huis, maakte kokend water, maakte sagopap, zat neer (en) at het. En de schoonzusters zeiden: eet gij dat, smaakt het goed? En de schoonzuster zeide: zou 't niet lekker zijn? 't is ons eten, wij eten dat. En zij vroegen haar haar ook (er mede) te voeden. En terwijl zij haar voedde aten zij, en daarna braakten zij houtskool, want de sago verhitte hunne buiken. Alle dagen klopte zij sago, voedde haar met sago, tot het braken ophield; zij braakten het houtskool tot 't op was, vervolgens braakten zij niet meer. Vervolgens bleven zij tot de vrouw baarde. En toen de jongen wat groot was, zeide de moeder tot haar man: laten wij vader gaan zien! En haar man zeide: waar is uw vader? En zijne vrouw zeide: hij woont in ons huis, ik weet niet of hij gestorven is. En haar man was boos op haar, zeggende: hoe is dat dat gij niet zeidet: laten wij gaan! wij halen hem, ik draag hem! waarom verborgt gij dat? En toen gingen zij. En de vrouw zeide: hoe zullen wij vader meenemen? En haar man zeide: wat is er dan? Maar zijn vrouw zeide: wat er is! hij kan niet loopen, hij is krom! Al loopende zocht haar man medicijnen (bladen en kruiden) en nam ze en deed ze in een bamboe-koker, En zij gingen tot haar vader in 't huis. Maar de vader had al zijn eten reeds opgegeten, en de honger plaagde hem dat hij bijna stierf; hij ging naar achteren, begroef zich in de asch, en lag neer. En zijn dochter klom op ('t huis in), ging hem zoeken, ging naar achteren, zag hem liggen in de asch. En zij stak hem hare hand toe, nam haar vader op uit de asch, bracht hem naar voren, haalde water en wiesch de asch van hem af. Vervolgens kookte zij eten voor hem. Hij at tot hij genoeg had. En de schoonzoon beval hem zijn handen op te steken, zich vast te houden aan een balk, hangende. En de schoonzoon trok (aan) zijns schoonvaders beenen, maar zij waren stijf (opgetrokken). En hij riep zijn vrouw om een bamboemesje, en zij bracht het mesje aan haar man, en haar man sneed zijns schoonvaders kniepeezen, en vervolgens stortte hij (de onderweg in een bamboekoker verzamelde) medicijn op de wonden. En daarna 
kon de schoonvader loopen. De schoonvader was verheugd. De schoonvader zeide: Wel! dat wat dit vermag is zeer goed! Ja! mijn eerste schoonzoon, ware die alzoo (geweest)! maar die was slecht, hij was gierig voor mij, en mijn laatste schoonzoon die is goed! En de vrouw zeide tot haar man: gaan wij weg? Maar de vader zeide: wij blijven hier, wij zullen eerst zingen; is dat gedaan, dan gaan wij. En vervolgens gingen ze sago overbrengen naar 't huis. En toen zongen zij. $\mathrm{Zij}$ zongen tot 's middernachts veel menschen in 't huis stegen, tot het huis overvol was. En de schoonzoon riep: kook eten voor deze dansfeestgenooten! maar de schoonvader zeide: niet noodig! er zal iets anders (gebeuren). En te middernacht steeg eten van onder 't huis op tot het huis overvol was. Vervolgens aten de dansfeestgenooten het, zij aten tot zij niet meer konden. Een jongen zeide: ik heb gegeten, ik wil niet meer! In eens hield het eten op. En de menschen zeiden: waarom sprak je alzoo? $\mathrm{Nu}$ is het eten weg van ons, wij zullen niet meer eten, wij zullen hongeren. En dat afgeloopen zijnde, zeide de schoonvader dat zij vertrekken (zouden). Maar de schoonzoon zeide: wij blijven maar hier!

XIII. Karubukawi.

Karubukawi tawai nina, nia na Wanduni raui na sweb. Niè têrai biba tapè pibèrèkari rumwaja, ma niè rupai beasa mònu. Bwabwin Windèsipèsi tuter aantumbwabwinpai niè têraipai marei ma niè sanè baba, sunda sunmun andio. Aantumbwabwinpai miun Karubukawi niè andiopai, rawesipai si beurar rawesi si bènikwai. Kiutu, andiopai dinanaar diòtò : ênda! peueran jau be? Didjawaba, pieran eja, andiopai dinanaar eja: ênda! pueran jau be? Aantumbwabwinpai tiòpan so sinjani: awini! inè andio sitateen beja! Biora si, kisjees si tuter waipaisi, si marera wora. Karubukawi ditawi sinjani tuter waipai. Sinjani tiò bibur, siaaw aantumbwabwinpai, bape Karubukawi bedjoor i, diawi sinjani, kioor aantumbwabwinpai so sweb misoi tuter bwinieempi, sunrònê $\mathrm{i}$ be aantumbwabwin. Sinjani bibur so sasi rau dinòta aantumbwabwinpai bape riama so $\mathrm{i}$ ba, ria riwàni eja siaaw $\mathrm{i}$ ja, bape Karubukawi riarê diawi i to diru, sinjani dinbabur i. Aborè rawiniena aantumbwabwin sawani diutan $i$, ma sinjani diòtò : Karubukawi bidjoor i, i saserei to diru. Inèni kausapa kawàsa pau senbò sensaserei i, senbur taburan so i, mamò Karubukawi 
diơtò: janina! Bape kawàsapai sensèmua iba senbabur eja. Inèni Karubukawi kioor i, misoi tuter aantum na swebêpai. Inèni mênâu, sawani biò didun. Didun biò ma, sentindu pimanda. Mênau, inèni mararia biba na swebêpai. Inèni sinjani sunmasasoba, aborè Karubukawi ria miun kaween. Kausapa ria ja miun kaween eja. Marariapai inèni biba to, inèni diò so tapuni, siaaw Karubukawi be tapu, diòtò: apusi! sue apai so jau tuter kamarèni, aborè tunda rau imun pi. Inèni tapuni sië apai, disain kamarèni, inèni sunda. Inèni tapuni sijoor bidjoor $\mathrm{i}$ biata na rubuanpai, mararia ria rau miun pi.

Aborè Windèsipaisiat sendoi sentòne pi so Joppipaisiat, aborè inèni Joppipaisiat senbo ma so Komar. Inèni sensajoor are sensajoor marariapai mium pi. Sensajoor $i$, ma rupai marei, inèni sentòpan: teïni ria miun pi nè? Aniosepèsi esa ba nanina! Inèni senbo so Windèsi séntutan sentòpan: teïni mium pi na jiš̌pai? Sentòtò : amanè esi ria ba, bape amanina wura. Kausapa, sendoi to mênau senbabur. Senbabur inèni sennanari rait so i. Inèni sinaja tapuni sunsubi eja, inèni mararia ria rau ja miun pi ja, raitpai sentau so i, sentò sentapur $\mathrm{i}$, tapuni diatar raitpai, sunbabur eja so sunnè aniopai. Iněni Joppipaisi senbabur sentònè aniopaisi. Kausapa senda ja senkoor rait Dòsnirpaisiat eja, senda ja ma sentaramaan sanu ja. Amana tapuni diatar siat eja, tapuni diatar beja siat, senbabur eja so sennè aniopaisi. Dòsnirpaisiat sentòpan: amatapuri bape tapuni miaasê beja. Joppipaisiat sentòpan so Dòsnirpaisiat: mentò menmasoi, amanda ja amankoor rait Waropan amantaramaan i ja abe amantapur i. Inèni senbò ma sentir wapaisi sentaramaan sanu ja. Inèni sinaja marariapai diòtò: apusi! tunda ja rau tunmun pi. Inèni sunda rau raitpai tiau so sanu, tapuni diatarê siat, sunbabur eja so sennè anioswebêpai. Inèni Jop senkoor rait Wandàman, senda ja ma sentamaan i ja. Kausapa sunsubi eja, sentau so sanu ja, sentò sentapur i, tapuni diatar siat ja. Joppipaisiat sensanemkariria marariapai beja, apa senkoor rait Wasjor eja, senda sentaramaan sanu ja. Kausapa sunsubi eja sentau sanu ja, tapuni diatarê siat ja, senda ja bape senmun sanu ja ba. Apa Joppipaisiat senda ja senkoor rait Masopai eja. Senda ma sentamaan sanu ja. Kausapa sunsubi eja na rau, sentau sanu bape tapuni diatarê siat beja, senbabur eja so sennè aniopaisi. Inèni Joppipaisiat sentòpan so Windèsipaisiat, marariapai tamaani siènendik $i$, diòjò: kausapa ja i tapur i! Diru senbos aje, kausapa tapuni sunda 
rau, inèni ria rau miun pi. Inèni sentau so sanu, aborè tapuni dinanaar: bubur tapè nina! Aborè marariapai dipaira, dipai bari tamaani Windèsipai, tamaani tipur i, Karubukawi tiò bedjoor i bape miraru ba, tamaani kioor $\mathrm{i}$ berusuwa $\mathrm{i}$ to, raitpai mênau pena. Joppipaisiat sensa so wapaisi sensaaw marariapai, sentòjò: mentònê amannèwi i ma! Amana tamaani diòjò: bwinieempi utan nia pena, abe inè marariapai ina! Inèni Joppipaisiat senbabur senkasjo Windèsisiat.

Inèni Karubukawi bibur are aantumbwabwinpai diutan: marariapai aninò? Karubukawi diòtò: irinba rait witoi amunda rau senkoor i pa. Apa sinjani sieis na swebêpai to kariria besiri, aborè djeuso tamaani kariria besiri. Inèni Karubukawi diònê niè těrai be wa, diònê karupai be wararò, diònê sanèpai be wasama. Inèni diriën niè pisjaanpaisi so wararò. Inèni ria rau diaas, diaas arau piapar Maso, sieis, saserei tapuni, diòtò: aniose tèi au, menmun tapupai nanu pa nè? Amana Masopaisiat sentòpan: aman ma, amanmun manu ba! abo buaas sueis, suserei so nu Nufoori rauri! Rawiniena piapar so nu Nufoori rauri na, ma sentòjò: aman ma, amanmun tapumui manu ba, abo susereitapumui mamò rua rau; suabu dira rau, rau ra puapar mamò nu Kemipai. Inèni diaas $i$, tiò mirutu, inèni piapar na diru. Kausapa senda sensajoor i, sentutan i. Aborè riaarê siat: jau Karubukawi, isaserei tapupai! Sentòjò: aman ma woroi beja amandamatu amanmun manu ba. Abo suserei tapè aniose janèsi apui. Inèni diaas, riama so aniosepèsi, diutan siat: menmun tapupai nanu pa te? Ma sentòpan: aman ma pibai! Nini diaas eja to riama na Sarêwàti, diutan siat eja, ma sentò: aman ma amanmun manu ba! Inèni bibur eja diaasê siserei sisapai na pui. Diaasê to berandumi, diaasê to piapar Menukwari, diutan siat eja. Amana sentòjò: aman ma amanmun manu ba! Inèni bibur eja riama piapar na Waraja, diutan siat eja. Ma sentòjò: aman ma amanmun tapuni manu ba. Inèni bibur eja diutan Sjaripaisiat. Ma sentòjò: aman ma amanmun tapumui manu ba! Inèni bibur eja riama so Wairur; diutan siat ja. Inèni sentòjò: Windèsipaisiat senmun manu pa! Inèni didjawa, diaas eja. Inèni riama so Windèsi. Inèni diaas warir parai Sòrèwunè. Inèni tapuni ria pon diòsa didjariri tapuni sieis pa. Inèni diò apui so tamaani, diòtò: jaiję! apusi ni diaasê pa nè siserei jau. Inèni tapuni diaas mare, mararia diòtò: janina! Inèni diaas maso mararia tamaani niè aniopai. Inèni mararia diòj', so tamaani, diòtò: jaijê! muteit 
apusi penai! wama! tunsarapi apusi maji! Muteit apusi pênai! rut na apusi rupai rawesi ma irut na rawesipai, tuntir i maji! Muteit $i$ pènai! têrai nini ma têrai saredjeu nina, têrai wàtan pa ma ajandami tapè bierwana so awini nanu na sweběpai. Inèni sunserapi majis, inèni sunkariawasi. Marariapai kiaar tapumi niè randumipai, diris $\mathrm{i}$ raria nini na worepai. Inèni tapuni tiòpan se marariapai: buris jau na raria nini, kausapa tamamu munnanari wapêsi munkoor jau ajis.

Inèni marariapai tamaani diònê womenpèsi so Karubukawi, diònê wapai kòta, diònê raarpaisi pau besiri: sisê, paarwasiê, sêrakê, sampaarê, janêsi wura. Inèni kausapa senmarandin wapai, banderapai mònu na wara wàtan, mònu na warasara, esi na wapon, esi na wapui. Inèni senbiaar so wapai, inèni senbiaar awaab Karubukawi so ruran rawa tawaipai biata, inèni biesinjontu wàtan, marariapai tamaani riapau i na sêlendang. Inèni tamaani mirandin to wèsjeen, siraab rupai, marariapai kòta mirandin kòta. Inèni senbiaar senbò, Karubukawi diòsa na wòriopai, mararia tamaanipai diòsa na kenani warawàtan, marariapai diòsa na warasara. Inèni sentipu sadip tuter mabon, sendoi bur Wandumi raro. Inèni mararia sinjani diòtò: jai ria! sièmuai tapuni to! apa sendoi i ma pa. Inèni sinjani sioruran pimandapaisi. Karubukawi bwinieempi diòtò: inèni buòn marandin! Inèni marariapai sinjani mirandin. Inèni siubi marau, sijoor arau so siat, sijoorririn tamaani mamarariapai tuter sawani, inèni ria rau, sia wapai. Inèni Karubukawi biaar are, inèni bwinieempi Wòwòrui riarau. Inèni ria rau diriën Karubukawi niè tawaipai rawapai, ditarien niè raarêpai. Inèni Karubukawi kioor kawàsapai are, tiòpan: aniopai siubi! ma kawàsa senmasoi na. Niè sêramura nia deriasi maria dirèpai, aniopai nia na dore na mamasipai rabwan. Tiòpan: pisjaanpai pau! tiòpan: kambopai pau! tiòpan: diaanpai pau! tiòpan: nando pau! tiòpan: piròmipai wura pau! Senmasoi sentaan i. Inèni marariapai tamaani kioor bwinieempi, marariapai senbabur eja so Windèsi, sensa aniopai, mênau pena.

\section{Vertaling :}

Karoeboekawi was een slang, hij woonde bij den oorsprong der Wandoeni in een grot. Zijn lijf was groot als een manggastam, en hij had twee hoofden op één hals.

Een vrouw van Windèsi met haar dochter, wier lichaam blank 
van teint was, en die zwanger was, die beiden gingen pandanusbladen halen (voor slaapmatten). De dochter sneed van Karoeboekawi's pandanusbladen, die waren aan één kant rood, aan den anderen kant geel. $\mathrm{Zij}$ sneed de pandanusbladen, die riepen zeggende: hè! waartoe hak je me? $\mathrm{Zij}$ luisterde niet en sneed weder, de pandanusbladen riepen weder: hè! waartoe hak je me? De dochter zeide tot hare moeder: moeder mijn pandanusbladen zijn zeer mooi! Zij boste ze en bond ze met lianen, waar zij gingen aldoor weer los. Karoeboekawi fopte de moeder met de lianen. De moeder wilde heengaan, riep haar dochter, maar Karoeboekawi verhinderde haar, beloog de moeder, nam de dochter mede naar de grot, zij bleef bij zijn vrouw; zij beiden telden haar als hun dochter. De moeder ging weg naar het strand buiten, wachtende op haar dochter, maar (toen) zij tot haar niet kwam, ging zij nog eens terug, roepende haar weder. Maar Karoeboekawi antwoordde haar valschelijk. Toen 't donker was verliet de moeder haar. Daarna 's avonds vroeg de man der dochter (naar) haar en de moeder zeide: Karoeboekawi verstopt haar, ik zocht tot donker. Den volgenden morgen roeiden vele menschen (om) haar te zoeken; zij bliezen de tritonschelp voor haar, omdat Karoeboekawi zeide (riep): ik ben hier! Maar de menschen haar niet vindende, vertrokken weder. Nadat Karoeboekawi haar (tot zich) genomen had, kreeg zij een kind in de grot. $\mathrm{Na}$ dat (alles) roeide de echtgenoot om (eten) te halen. (Van 't) eten halen terug geroeid, gingen zij (lett. hielden zij de rouwzaken) in den rouw. Daarna vervolgens (werd) de jongen groot in de grot. Toen de moeder en hij beide verlangden naar dierlijk voedsel, ging Karoeboekawi garnalen vangen. Den volgenden morgen ging hij weer, ving weer garnalen. De jongen onderwijl groot geworden zijnde, zeide tot zijn grootvader hij noemde Karoeboekawi grootvader - hij zeide: grootvader! snijdt een boog voor mij met vischpijlen, dan gaan wij zeewaarts (en) ik vang visch. Toen sneed grootvader een boog, scherpte vischpijlen, en toen gingen zij. Toen, terwijl de grootvader paste op hem, lag hij op 't zand; de jongen ging in zee visch vangen.

Daarna, toen de Windèsiërs zongen, gaven zij ook wat aan de Jop-ers. Vervolgens roeiden de Jop-ers hierheen tot Komar. Toen zij landwaarts zagen, zagen zij een jongen visschen. $\mathrm{Zij}$ zagen dat zijn hoofd roodachtig was. Toen zeiden zij: wie is dat 
die daar visch loopt te vangen? Niet ééne Kampong is hier! Toen zij naar Windèsi geroeid waren, vroegen zij zeggende: wie is dat die daar boven visch ving? $\mathrm{Z}_{\mathrm{ij}}$ zeiden: van ons is niemand gegaan, want wij zijn allen hier! Den volgenden morgen het zingen afgeloopen zijnde vertrokken zij. Weggaande maakten zij hongi naar hem. Toen 't laagwater werd, kwamen grootvader en hij weer uit. Vervolgens ging de jongen zeewaarts weder visch vangen. De hongi viel hem aan, willende hem vangen; de grootvader verjoeg de hongi; zij beiden vertrokken weder naar hun huis. De Jop-ers gingen naar hunne huizen. Den volgenden morgen gingen zij weder, zij haalden een hongi van Dosnirers; zij gingen weder en bespiedden de beiden weder. Edoch de grootvader joeg ze weer weg, de grootvader joeg ze bijzonder weg; zij gingen weer heen naar hunne huizen. De Dosnirers zeiden: wij vingen hem (wel), maar de grootvader is te dapper. De Jop-ers zeiden tot de Dosnirers: gijlieden wilt thuis blijven, wij gaan weer, wij halen een hongi van Waropen wij beloeren hem weer, opdat wij hem vangen. Daarna gingen zij roeien en haalden hunne prauwen op het strand, en loerden weder op hun beiden. Toen het laag water werd, zeide de jongen: grootvader wij gaan samen weer zeewaarts; wij gaan vischvangen. Toen zij buiten kwamen, overviel hen de hongi, de grootvader verjoeg ze en zij beiden keerden weder tot hun grot-huis. Daarna de Jop-ers haalden een hongi Wandàman, zij gingen weder en loerden weder op hem. 's Morgens kwamen zij beiden weer uit; zij vielen hen beiden weer aan, zij wilden hem vangen, maar de grootvader verjoeg ze weder. De Jop-ers begeerden den jongen zeer, dus haalden zij weder een hongi Wasjor, zij gingen die beiden weder belagen. 's Morgens toen zij beiden weder uitkwamen, vielen zij hen beiden weder aan, grootvader verjoeg ze weer; zij gingen weer, maar zij kregen die twee weer niet. Toen de Jop-ers weder gingen, haalden zij weer een hongi-Roon; zij gingen en loerden weder op die twee. 's Morgens kwamen beiden weer uit naar zee. Zij vielen die twee weer aan, maar grootvader joeg ze erg weg; zij gingen weer heen naar hunne huizen. Toen zeide de Jop-ers dat tot de Windèsiers, de vader van den jongen beroemde zichzelf, zeggende: morgen-ochtend vang ik hem! In den nacht roeiden zij naar boven, 's morgens gingen de grootvader en hij naar zee; vervolgens ging hij visch vangen. Toen vielen $z i j$ hen beiden aan 
waarop de grootvader schreeuwde: trek terug naar hier! Daarop liep de jongen dravende, liep aan tegen zijn Windèsischen vader; zijn vader greep hem, Karoeboekawi wilde dat verhinderen, maar hij was niet vlug (genoeg er bij), de vader had hem reeds weggenomen van hem. De hongi eindigende, de Jop-ers bestegen hun prauwen (en) eischten den jongen op, zeggende: doet ons hem bezitten! De vader echter zeide: het land (plaats) mijner vrouw is hier!, dus mij behoort de jongen! Daarop vertrokken de Jop-ers, boos op de Windèsiers.

Daarna vertrok Karoeboekawi landwaarts. De dochter vroeg hem: waar is de jongen? Karoeboekawi zeide: ik weet niet welke hongi, (toen) wij naar zee gingen, hem mede nam. Daarop huilde de moeder in de grot verschrikkelijk, tevens haar vader (n.l. Karoeboekawi) verwijtende zóó dat het erg was. Daarop deed Karoeboekawi zijn lijf een prauw worden, hij deed zijn rug het hol worden van de prauw, deed zijn buik de prauw-kiel worden. Daarna laadde hij zijn eten in 't prauwhol. Daarna ging hij naar buiten zwemmen; hij zwom zeewaarts, zwom te Roon binnen, huilde, zoekende zijn kleinkind, zeggende: welke kampong zijt gij? hebt gijlieden mijn kleinkind en mij bevochten daar? Edoch de Rooners zeiden: wij hier, wij bestreden u beiden niet! doch zwem huilende, zoek hem op 't eiland Noefoor daar buiten! 's Avonds naderde hij bij het eiland Noefoor daarbuiten, en zij zeiden: wij hier, wij bevochten u beiden niet, indien gij uw kleinkind zoekt, ga dan zeewaarts, breek (ga dwars over) den stroom naar buiten; daar buiten nadert gij dan het eiland Gébé (liggende in de straat van Djailolo). Vervolgens zwom hij tot hij bijna zonk; toen naderde hij (Gébé) in den nacht. 's Morgens gingen zij hem zien, zij ondervroegen hem. Toen antwoordde hij hen: ik ben Karoeboekawi, ik zoek mijn kleinkind! $Z_{\mathrm{ij}}$ zeiden : wij zijn hier te ver om tot $\mathrm{u}$ te komen, wij hebben $\mathrm{u}$ beiden niet bevochten! Dus zoek bij de kampongs daar onder (of achter). Toen kwam hij zwemmende aan de kampongs, vragenden: bevocht gijlieden mijn kleinkind en mij? En zij zeiden: wij hier niet! Dan zwom hij weer tot hij kwam te Salewatti, hij vroeg hen weder, en zij zeiden: wij hier wij bestreden u beiden niet! Toen ging hij weer weg, terug zwemmende en zoekende langs de kust. Hij zwom tot dat hij met zeeruig begroeid was, zwom tot hij Menoekwari bereikte, (en) vroeg hen weder. Edoch zij zeiden: wij hier, wij bevochten u beiden niet! Toen vertrok hij weer 
tot hij kwam aan Wariab, hij vroeg hen weer. En zij zeiden: wij hier, wij bevochten u beiden niet. Toen vertrok hij weder, hij vroeg de Sjariers. En zij zeiden: wij hier, wij bevochten uw kleinzoon en u niet. Toen vertrok hij weer, hij kwam te Wairoer, vragende hen weer. Toen zeiden zij: de Windèsiers hebben u beiden bevochten! Toen hij (dit) hoorde, zwom hij weer. Toen kwam hij te Windèsi. Daarna zwom hij om de rizophoren (hoek) Sòrèwoenè. Toen ging de kleinzoon naar voren (van 't huis), hij stond en hoorde zijn grootvader om den hoek komen, huilende. Toen zeide hij naar het achterhuis (d. w. z. hij keerde zich tot zijn vader die in 't huis was) zeggende: vader! 't is grootvader, hij zwemt hierheen, hij zoekt mij. Toen de grootvader landwaarts zwom zeide de jongen: ik ben hier! Toen zwom hij naar des jongens vaders huis. Vervolgens zeide de jongen tot zijn vader zeggende: vader! vrees grootvader niet! kom! trekken wij grootvader naar boven! Vrees grootvader niet! houd gij grootvaders hoofd aan eenen kant en ik houd het aan den anderen; wij trekken samen hem hierheen naar boven! Vrees hem niet! dit lichaam is maar wat ('t echte niet), het echte lichaam is er nog gelijk hij toonde aan moeder (en mij) samen in de grot. Toen trokken zij hem op, daarna schoten zij hem op. De jongen schoor zijn grootvaders zeeruig af, en legde hem te droogen in de zon. Daarna zeide de grootvader tot den jongen: leg mij te droogen dezen dag; morgenochtend maken uw vader en gij prauwen (klaar), gij beiden brengt mij naar boven.

Vervolgens gaf de vader van den jongen een slaaf aan Karoeboekawi; gaf ook een prauw, gaf zeer veel goederen: stukken katoen, borden, zilveren armbanden, schelpen armbanden, dat alles. Vervolgens 's morgens versierden zij de prauw, twee vlaggen rechtsch, twee linksch, een ander voorop, een ander achterop de prauw. Daarna daalden zij af in de prauw, vervolgens lieten zij Karoeboekawi naar beneden, want de afgestroopte slangenhuid deed hij af; daarna was hij een werkelijk mensch, en de vader van den jongen omgordde hem met een slendang. Vervolgens versierde de vader zich fraai, hij bond zijn haren op, ook de jongen versierde zich. Toen daalden zij af (en) roeiden. Karoeboekawi stond in 't midden der prauw, des jongens vader stond op de rechter laadstoel, de jongen stond op de linker. Vervolgens sloeg men op de staande trom en den gong, zij zongen, de Wanduni ingaande. Toen zeide de moeder van den jongen ('t 
is) vader! hij komt! hij heeft zijn kleinzoon reeds gevonden! daarom zingen zij, hierheen komende. Daarop ontdeed de moeder zich van de rouwteekenen. Karoeboekawi's vrouw zeide: nu kunt ge u versieren! Toen versierde de moeder van den jongen zich. Vervolgens ging zij uit zeewaarts, zij zag uit naar hen, zij herkende den vader, 't kind en haar echtgenoot, toen ging zij naar buiten en besteeg de prauw. Toen Karoeboekawi landwaarts afdaalde (aan land stapte) toen ging zijn vrouw Wòwòroei naar buiten, vervolgens zeewaarts gaande bracht zij over: Karoeboekawi's slangenhuid, en bracht zijn goederen over. Toen nam Karoeboekawi de menschen mede landwaarts, en zeide: huis, kom uit! en de menschen (konden) er in zitten, zijn jongelingshuis stond aan den waterkant, het huis stond landwaarts midden op de boomlooze drassige vlakte. Hij zeide: veel eten! hij zeide: veel drinkwater! hij zeide: veel visschen! hij zeide: veel pisang! hij zeide: veel allerlei tuinvruchten! Zij zaten en zij aten het. Daarna nam de vader des jongens zijn vrouw en den jongen; zij vertrokken weder naar Windèsi, zij stegen in 't huis. Uit is 't.

\section{So Ansusipaisiat sentarien.}

Ansusěpaisiat bepapon sennai na Papararò, siat tuter Windèsipaisiat senme siat ba, senbemanèta, sentaan wura aimupaisi. Ansuš̌paisiat sentaum wonapai mònu, bape sentimun pimuna ba. Kausapa senda sentòn ròmi wenasja, rawiniëna sentena, diru wonapai sanu sunsasi so rerabwanpai. Bwisaarpai mònu sundèpupui, mansaar ria moja ba, kausapa bwisaarpai sanu sunsubi ari, suntaar wonasasipai. Inèni sunkasjo sunròtò: mentaum wona ma menmun pimuna ba, sisasi sarédjeu so rerabwan. Raria wura tapèna, diru wura tapèna, to raria esi wura. Inèni rariapèsi babapaisiat sentòpan: marariapai! menda! menkoor wai, menkoor soman, menkoor sendèwara abe tannanari wapaisi abe mentarien tannè piròmipaisi abe tanbabur bwabwinaisinjani sanu tuter mansaarpai. Bape mansaarpai nièwori niè kawàsapai. Mansaarpai sanòpai: Kurisipi, ria moja ba, kiaas i, kisjo bwabwinpai sanu, diòtò: nani munnunum pi so jau, munkoor airamuan so jau, munkoor kambo so jau, nani pibai pe? Inèni senbarirui, mansaarpai bwisaarpai sanu senbarirui. Mansaarpai niè kawàsapai sanu senbarirui. Mansaarpai niè kawàsapai sentòtò: amanbabur pena! Kausapa sensjaar wapaisi, sentariën, saria senbabur. Sen- 
babur, bwisaarpai sanu sunseis, mansaarpai diòtò : jè! munròtó abe senbabur tatat tapè janè! Senbòs' sunraas rusar siat, esipai warasjaaw sendewapupai, bape senkibarpidiaar i tuter bòpai, senteuso sanu: munròtò munroi so amat so wonasasipai, munbabur are, mundaut Kurisipi abe menmasoi! Inèni senbabur. Senbabur arau sentoi are so Kurusipi, sentòtò: Windèsipaisiat senrin amanbabur nè ba sensaserei amat, mamò tuòpan so siat: senbòs' arau, sensaserei amat na Maso, nupai be kawàsa beja, nani sensaserei amat na nupèsi wesje.

Inèni senbabur arau so Maso, bape kawàsa pau beja. Inèni sentutan Masopaisiat sentòtò : nupèsi nia na dorau wana? Masopaisiat sentòtò: nu pimasa nina. Inèni Ansusěpaisiat senbabur. Senbò, sensasi, senkarieri, senkai pi sisjaanmomapaisi so rawanampai, sibejawar na rau so Ansusa, ma sensaaw jawarpaisi nini be abioi Sendini. Senda rau so nu Ansusa sentin na i na.

Bwisaarpaisanu sunberěwuki, esipai runandaupai sibusar runandaupaisi sibediwa, be kondi. Bwisaar esipai runandau siri biëaidiaan. Wonapaisanu sunberěwuki. Masaarpai niè aniopai bie sweb, sipai biërěwuki biba dirieu, dibakiri, titura wěnasja. Tapèna to. Sennè kankomi siri sanōpai: Aantatòbi, bape miasa to.

\section{Vertaling.}

Waarom de Ansoesers verhuisden.

De Ansoesers woonden vroeger aan de Papararö, zij met de Windèsiërs. $\mathrm{Z}$ ij verspeelden elkander niet (zij leefden in vrede), zij waren bevriend; zij aten allen de boomvruchten. De Ansoesers voedden twee honden, maar zij vingen geen varkens. 's Morgens gingen zij; zij maakten slechts tuinen; 's avonds sliepen zij; 's nachts poepten de twee honden in het midden des huizen. (Er waren ook) twee bijna blinde oude vrouwen en een oude man die niet loopen kon. (Als) 's morgens de oude vrouwen naar buiten kwamen trapten zij in den hondedrek. Toen werden zij boos zeggende: jelui voedt honden en jaagt geen varkens, zij poepen maar in 't middenhuis. Elken nacht, elken dag, 't zelfde alle verdere dagen. Totdat op een dag de grooten zeiden: jongens, gaat, haalt rotan, haalt dwarsleghouten, haalt vlerkhouten, opdat wij de prauwen maken, opdat gij onze tuinvruchten kunt laden, opdat wij verlaten de twee onde vrouwen met den ouden man. Maar de oude man trok zijn menschen voor. Des ouden 
mans naam (was) Koerisipi, hij kon niet loopen, hij schoof. Hij was boos op de oude vrouwen, hij zeide: zult gij beiden voor mij koken, zult gij beīden brandhout voor mij halen? water voor mij halen? dat zult gij nfet! Daarop twistten zij, de oude man en de twee oude vrouwen twistten. Des ouden mans volk zeide: wij vertrekken. 's Morgens werden de prauwen klaar gemaakt en geladen; den tweeden dag vertrokken zij. (Toen) zij vertrokken huilden de oude vrouwen, de oude man zeide: hè: om jelui gepraat, daarom verlaten zij ons aldus. Toen zij roeiden, zwommen beiden hen achterna, één hing aan het achtereinde van 'n vlerkhout, maar zij stootten ze weg met een roeispaan, zij verweten haar: jelui praattet en zongt tegen ons om den hondedrek, gaat terug naar land, trouwt Koerisipi, opdat gij blijven moogt. Daarna vertrokken zij. Zeewaarts gaande zeiden zij tot Koerisipi, zij zeiden: de Windèsiërs weten niet dat wij van hier vertrokken zijn, zij (zullen) ons zoeken, daarom zegt gij tot hen: (dat) zij zeewaarts roeien, zij (moeten) ons zoeken te Roon; (zoo) dat eiland te veel volk heeft, zoeken zij ons op een ander eiland. Toen vertrokken zij zeewaarts naar Roon, maar (daar was) te veel volk. Toen vroegen zij de Rooners: is er nog een eiland daar buiten? De Rooners zeiden: een groot eiland is daar. De Ansoesers vertrokken. $Z_{i j}$ roeiden, zij poepten, zij urineerden, zij wierpen van 't eten de kruimels in zee, die werden banken buiten Ansoes, en zij noemen deze banken: de brug Sendini. Zij gingen buiten naar 't eiland Ansoes, zij zetten (hunne huizen) daar op.

De beide oude vrouwen werden steenen; van de eene haar grijze haren die werden alangalang en riet. (Van) de andere oude vrouw: één haar werd een diaanboom. De beide honden werden steenen. Des ouden mans huis werd een spelonk, zijn penis werd een groote lange steen die af hangt en aldoor droppelt. Aldus is het. Hun muskaatboom heet Antatobbi, maar die is dood.

\section{Kawĕrai.}

Kawêrai tamaani, niè madjawipai, raarwo bwabwinpai senmasoi to sinjani biòru. Tamaani mièser i misoi tuter siat. Senmasoi to raitpaisi senmun siat wura to tamaan kòta biòru. Kawêrai tuter madjawipai, raarwo bwabwinpai senbetòru. senmasoi. Bape raitpai sendatawan siat, sentòtò: senpaba. Kawêrai djeuso madjawipai, raarwo bwabwinpai, diòtò : raitpai sio to tanpa Dl. 70 . 
ba! Inèni senbabur to, raarwo bwabwinpai pia ba, biata diena. Kawêrai diò biaun i, bape raarwo bwabwinpai diena siat beja. Kawêrai tiòpan: sanèpai diò tanmasoi na nina. Inèni Kawêrai pir ariri sennè aniopai nini, siaaw: awini, jai, sunrawin jau i besinjontu wàtan, itòpan: anio nè diòsa! Inèni aniopai diòsa, biaun raarwo bwabwinpai, diòtò : buòsa, kuoor tannè pigangènasi ajis so tannè anio. Menau inèni senmasoi na i. Rawiniena tiòpan so madjawi: kausapa Kawêrai madjawipai ria diweer, miun pimunapèsi so tatat. Sentena to, kausapa tiòpan so raarwo bwabwinpai: niunum taunpaisi so Kawêrai madjawipai, simasa to kioor $\mathrm{si}$, ria. Ria pa, miun pimuna siri, mitauni raarwobwabwinpai sanu sunmasoi sunraan. Rawiniena madjawi bibur ma, tiòpan so babai: Kawêrai madjawi miun pimuna siri. Sennunum i, sentòtai $\mathrm{i}$ to keis, siaaw so raarwo bwabwinpai diòtò: Kawêrai raarwo bwabwinpai niunum pi, Kawêrai raarwo sentaan tuter madjawipai. Rawiniena ja tiòpan so madjawipai eja: kausapa Kawêrai madjawi ria, ria diweer eja. Kausapa ria, raarwo bwabwinpai sunmasoi, siaaw so raarwo bwabwinpai: Kawêrai raarwo bwabwinpai niunum pi so Kawêrai sunraan. Niunum pi to, sunraanpi to mênau, rioram winioipai, diò kioor $\mathrm{i}$ apui, diò biubu kambopai, biubu i to, sijoor are, sijoor rait, ruran esi nia na aniopai warare rawesi, esi nia repuipai, esi nia reponpai. Raarwo bwabwinpai siaaw: Kawêrai! kabio tuòpan pena! Kawêrai diutan i: witoi nina nè? Raarwo bwabwinpai tiòpan: witoi? bape rait! Kawêrai tiòpan: Kawêrai raarwo bwawinpai bibur nanari ma pon. Inèni Kawêrai diosarě, siraab niè apaipai tuter atopaisi, dipai apui, diana raitpai ruran na repuipai kieis, diana na anio warare rawesipai to kieis eja, diara i diana rawesi ja to kieis eja, dipai so anio reponpai diana to kieis eja. Senbòru to senkeis wura, siri mièser bibur. Bibura tiòpan: amanton $\mathrm{i}$, bape mië amat, amanpa i ba. Ma esiat senmasoi sentòpan: mia ma apa menpa i ba pa, amat rèto, nani amanpa i. Kausapa senda ja. Kawêrai madjawi kòta ria diweer eja, raarwo bwabwinpai sunmèseri sunmasoi, siaaw so raarwo bwabwinpai eja: Kawêrai raarwo bwabwinpai niunum pi, Kawèrai sunraan. Niunum pi to simasa, sunraan si to keis, rioram winiopai eja, kioor kambopai apui, diò biubu i, sijoor eja rait tapè papon: ruran esi nia na repuipai, esi nia na anio niè warare, rawesipai esi nia rawesi, esi nia reponpai eja. Raarwo bwabwinpai siaaw eja: Kawêrai! kabio tuòpan pena! Kawêrai diutan i: witoi? Raarwo bwabwinpai 
tiòpan: witoi? bape rait! Kawêrai tiòpan so raarwo bwabwinpai: Kawêrai raarwo bwabwinpai bibur nanaria ma pon! Kawêrai tibasaar, siraab niè apaipai tuter niè atopaisi, dipai apui, diana, diana ruran benai repuipai to kieis, diare $\mathrm{i}$ eja so anio warare rawesi to kieis eja, diare i so rawesipai eja kieis, dipai eja so reponpai, ma diana siat to senkeis eja, siri bibur eja, tiòpan eja tapè bepaponpai tiòpan: amanton i, bape amanpa i ba. Bemasopaisiat sentòpan: mia ma apa menpa $\mathrm{i}$ ba, aman rèto. Tapèna raria wura: senda senton i tawana, bape miun siat tapèna wora, sentòtò: tanton i tapènina, nani tanpa tanmun i ba, tansaserei sinjontu siri, ria diawi. Ma masaar siri tiòpan : nani ira abo jawi, riama tanmun i. Ma inèni masaar ria, ria re. Kawêrai raarwo bwabwinpai ria pui, sijoor are, sijoor masaarpai, siaaw eja so raarwopai: Kawêrai! rait! Bape masaar nini tiòpan: raitba, jau tapumui, jau ja, jawin tamamui. Kawêrai siaawi: ruama! Masaar ria rau, siajis. Kawêrai diutan i: apusi! katu ruama so? Masaar tiòpan: irama so piësi ba, bape sentò sendoi, sentòně roi nine be jau, tapèna sentòpan: mèmu madjawi munmasoi na nina, joira so manu abo isaaw raar so manu, abo tantitaan roi wani. Ma Kawêrai tiopan: wèsjeen, nani jonê maso au. Mansaar tiòpan: menkoor si, tantinda wura. Bape Kawêrai tiòpan: kuoor raarěnèsi apon, nani kausapa amanda ma tu. Ma masaar tiòpan: menda, nani irama, janòta miat, buawia jau pênai. Kawêrai diòtò: sa jawi au ba, nani amanda ma tu. Mansaar tiòpan: menda tindia, nani jònê sennunum pisjaan, abo ikoor si, ma janòta miat. Ma Kawêrai tiòpan: wèsjeen! nani budjaawbedjoora Kawêrai madjawi niè pandòtu nè. Ma Kawêrai dimis raarwo bwabwinpai niunum pisjaanpai to piaur, ma tiòpan so Kawêrai: tanda, ma na imateit beja. Ma Kawêrai tiòpan so raarwo bwabwin: muteit so? tanda abo mujis. Ma Kawêrai raarwo bwabwin diò kioor niè pimirandinpèsi esasi, ma esasi sibata, bape Kawêrai tiòpan: muteit pênai! kuoor si wura. Raarwo bwabwin kiòrusaar Kawêrai, ma kioor si wura. Inèni senda rau, masaar riama papon dinòta siat, didjawa Kawêrai madjawi biaarě niè pandòtupai, ma mansaar tiòpan: Kawêrai madjawi sundama to, apa madjawi biaar niè pandòtu pa. Sundama so masaarpai, sunramis i bibur papon, rawiniena sentòru senda rau. Masaarpai siaaw: mensa ma jis so anio nè! Bape Kawêrai miajar ba, tiopan: Kawêrai kimbêrei sia ma jis, Kawêrai diò diena na djo nè. Inèni sennanari jaba katupèsi. Pokomuan Kawêrai tiòpan so raarwo bwabwinpai: Kawêrai 
raarwo bwabwinpai mirandin! Kawêrai madjawipai mirandin kòta! abe tanda, Kawêrai raarwo bwabwinpai miji. Ma sentòru senda sensaji, esi diò rioi, Kawêrai siodiai siat, diòtò: menpeja! Kawêrai madjawipai rioi! Rioi, senmaji to mênau, esi diò rioi eja, bape Kawêrai siodia i eja: asisi miat! Kawêrai madjawipai rioi! Tapèna diru Kawêrai madjawipai mièseri rioi to sasaar. Ma inèni sentaton so siat, sensawäuri sensènendik siat. Bape Kawêrai kiòpas ajis aimarabopai sitaitu. Tapèna to sasaar: senkabio katu, kiòpas ajis aimarabopai siteitu. Ma raarwo bwabwinpai tiòpan so raarwo muanpai: Kawěrai! senmun tatat pe! Ma Kaw rrai tiòpan: muteit? To sasaar baba senbiaar senbabur awaab so sennè jabapai. Kawěrai tiòpan: Kaw rrai raarwo bwabwinpai, Kawěrai madjawipai sundèmon ma sunrena! Kawěrai raarwo bwabwinpai misoi diaran ma tiòpan: munrena berusua jau è? Kawerai tiòpan: muteitè? Sentò senkabio, nani buaun nanu. Ma senkabio katu, biaun sanu, Kawěrai tibasaar are, tiaratu wonapèsi, nandopèsi siteitu. Tiòpan so raarwo bwabwinpai : Kawerai raarwo bwabwinpai rèmon ma diena sarědjeu. Bape tiòpan: jena, bape imateit beja! Tapè jana to rawiniena. Ma Kawěrai tiòpan eja: Kawerai raarwo bwabwinpai mirandin, Kawerai madjawipai tantòru tanda tanmaji eja. Ma pokomuan senda sensajis, esi diò rioi ja, Kawerrai siodiai eja: menpeja! Kawèrai madjawi mièseri rioi! Senmaji to menau, esi diò rioi, siodiai i ja: menpeja! Kawěrai madjawipai mièseri rioi! Mièseri rioi sipar to sasaar. Inèni sentò senmun siat ja, risěpai mitòtap sentau bur sanu. Bape senpa sanu ba, madjawipai pieran rawesi, babai pieran rawesi na anio, sunperan siat to keis: bwabwin, muan, mararia, senkeis wura, masaar katupai diawia sanupai, diòsa na atorè repuipai, diò bedjoor sanu, bape sentaratu i kòta. Měnau, inèni sentòru senbiaar senbabur are so sennè aniopai. Ma inèni senmasoi to sinjani tamaani riama so siat. Raarwo bwabwinpi diò ria ja pui, sijoor i, siaaw eja so Kawěrai: Kawěrai! kabio tuòpan pena! Kawerai tiòpan: Kawěrai raarwo bwabwin diòtò? Ma tiòpan: jòtò? bape rait! Ma Kawěrai tiòpan tapè papon eja, diòtò: Kawerai raarwo bwabwinpai bibur nanari ma pon. Ma inèni diòsa siraab apaipai tuter atopaisi, dipai apui. Kawerai diutan tapuni, tiò: tei au ? Ma tapuni tiò: jau sinjamu tamaani jau! Siaaw tapuni, diòtò: ruama rau! Ma tapuni riama rau, sijoor ririn $i$, tiòpan so madjawi: nini tantapuni bewàtan! awini tamaani nina! Ma inèni siajis, ma tiòpan so tapunisiat: imasoi, bape raria wura jadjawa: rait diò miun 
miat tawana, tapèna jò irama ikoor miat. Ma tapuibabai : tiòpan : wèsjeen apusi, nani tantabur. Ma inèni tapuni sio siat, senbabur arau so sennè aniose. Ma senmasoi to, siaaw tiòpan: aniose miat te? tanberait. Ma aniosepai sensjaar wa babapaisi wura senbò to senkeis wura. Ma katim siri diawia, diòjò piòta, ma misoi. Bape sanè so Kawerai raarwo bwabwinpai, so nini diawia, diòjò: piòta. Ma dimis raarwobwabwinpai tuter sabu, sambako maso Kawĕrai raarwo bwabwinpai. Bape raarwo bwabwinpai Kawěrai diniau i, tiòpan: musoi to, esi dinatu pi so au, buaan si pennai. Ma diaan si ba, pi, si bata na bajapai to raarwopai sunbabur ma. Bape piro tiòpan si so raarwopai. Ma inèni raarwo siaaw: Kawěrai raarwo bwabwinpai kioor inè bajapai ma! jò jaan sabu. Ma raarwo bwabwinpai kioor i ja, Kawerai diò diaan sabu, bape sijoor sabu, sambàko sitabaan ma sibata na bajapai, ma Kawěrai diutan: Kawerai raarwo bwabwinpai, tabaan to nini biata na baja nè? Ma Kawěrai raarwo bwabwinpai tiòpan: sinjontu siri be masopai niè pi diònepaisi na, bape iparo itòpaně si so au. Ma Kawerai sanèwèsjeen, dimiaas wèsjeen, dion nièwi, diòně niè wa baba sura, pi bepau jani wura. Ma tapèna muan diòně si wura witoi siaaw. Sièmuai si wura, siaaw muanpai raarwobwabwinpai baba kòta. Diòně so Kawěrai riaut i, Kawěrai i kòta biaat wa sura, women sura, pi boreipai wura, tapè diropai diòně pa. Ma inèni senmasoi to senberait eja, senmamuna to senbabur. Ma Kawěrai siaaw raarwo bwabwinpai. Kawěrai raarwobwabwinpai riama, siraab airawinèsi tuter inè womensiat. Bape raarwo bwabwinpai sawani miajar $\mathrm{i}$ ba, rè bedjcor $\mathrm{i}$, miajar ria so Kawěrai ba. Bape Kawěrai dimis to raria woroipai to rawiniena. Inèni raarwo bwabwinpai riama. Ma Kawěrai raarwo bwabwinpai diawin mararia muanpai siri. Tapèna riama Kawěrai sijoor ririn iba, tiòpan: nini Kawěrai raarwo bwabwinpai anina ba. Bape riama deriasi sijoor ririn i, tiòpan: tanè Kawěrai raarwo bwabwinpai kiriria beja? Ma kioor mani diòne piriaan i, ma kioor nioi, ditateer niè runandaupai to misisis. Ma inèni bedjoor i, misoi tuter i. Aantumpai sieis to senpa ba, sentòpan: Kawěrai diòně raarwo bwabwinpai ria so aantumpai, sieis beja, tòkato sieis to biòru pe. Bape Kawěrai tiòpan: sieis to biòru sarědjeu! tawana nianari inè raarwo bwabwinpai to kiriria, abo imajar inèwi ba. Ma senmasoi to diònanè muanpěsi riaut $\mathrm{i}$ berusua sawani. Ma muan beraut $\mathrm{i}$ pa diòně raarwo bwabwinpai so Kawerai, madjawipai dion riaut i. Měnau pena. 


\section{Vertaling.}

Kawèrai, zijn vader, zijn jongere broeder, zijne zuster woonden (samen) tot zijne moeder stierf. Zijn vader alleen bleef met hen. $\mathrm{Zij}$ bleven (bijeen) tot hongi's hen aanvielen, tot ook de vader stierf. Kawěrai met zijn jongeren broeder, zijne zuster, zij drieën bleven (bij elkaar). Maar de hongi's onderdrukten hen, zij zeiden: zij konden niet meer ('t uithouden). Kawěrai verweet zijn broeder en zijne zuster zeggende: de hongi's vervolgen ons tot we niet meer kunnen. Toen gingen zij weg tot de zuster niet meer kon, zij lag en sliep. Kawěrai wilde haar wekken, maar de zuster sliep te vast. Kawěrai zeide: ik denk zij zegt: wij blijven op deze plek. Toen legde Kawerrai houtjes uit overeenkomstig hun huis, hij riep: moeder, vader, zij gewonnen mij (dat) ik ben een man! ik zeg: dit huis sta. Toen stond het huis, hij wekte zijne zuster zeggende: sta op, breng onze bezittingen boven naar ons huis. (Dat) klaar (zijnde), toen woonden zij er in. 's Avonds zeide hij tot zijn broeder: morgenochtend gaat Kawerai's broeder op jacht, (dan) doodt hij beesten voor ons. Zij sliepen tot den morgen. Hij zeide tot zijne zuster: bak sagokoeken voor Kawerrai's broeder. Als zij klaar zijn neemt hij ze en gaat. Hij ging en doodde een beest, hij. (Kawěrai n.l.) en zijn zuster bleven en aten. 's Avonds kwam de broer terug, zeggende tot zijn ouderen broeder: Kawerai's broeder doodde een beest. Zij branden 't (de borstels n.l.) zij hakten 't geheel af, hij riep zijn zuster, zeggende: Kawěrai's zuster koke eten, Karwěrai en zuster eten met den jongeren broeder. 's Avonds weer zeide hij tot zijn broeder: morgenochtend gaat de broeder van Kawerrai, hij gaat weder jagen. 's Morgens ging hij; de zuster en hij bleven, hij riep tot zijn zuster: Kawerai's zuster koke eten opdat Kawěrai en zij eten. Na eten gekookt en gegeten te hebben, wiesch zij de etensbak, wilde die naar achter brengen om 't water uit te storten, stortte 't uit, zag landwaarts. $\mathrm{Zij}$ zag een hongi, één deel bevond zich bij het huisvenster, een ander deel aan gene zijde, een deel bevond zich achter, een ander deel bevond zich voor ('t huis). De zuster riep: Kawerai! wat zegt ge er van! Kawerai vroeg: wat is er? De zuster zeide: wat er is? maar een hongi! Kawerai zeide: Kawěrai's zuster trekke langzaam naar voren. Toen stond Kawěrai op, trok zijn boog met de pijlen, liep naar achteren, (en) schoot 't hongi-deel aan den achterkant 
weg, schoot aan 't huisvenster 't deel tot het weer weg was, keerde zich om, schoot weer dat deel tot 't weder weg was, liep naar 't voorhuis, schoot tot 't daar weg was. $\mathrm{Zij}$ stierven tot zij allen op waren, slechts één vluchtte. Die wegliep zeide: wij vielen hem aan, hij speelde (met) ons, wij konden hem niet (aan). En de andere die thuis gebleven waren, zeiden: gijlieden dus kunt hem niet (aan), wij daarentegen zullen 'm (aan) kunnen. Den volgenden morgen gingen zij weder. Kawerrai's broeder ging ook weder jagen, de zuster en Kawerai slechts bleven thuis. Hij riep tot zijn zuster weder: Kawerrai's zuster koke eten, Kawerrai en zij eten. $\mathrm{Zij}$ kookte eten tot 't gaar was, zij aten het op, zij wiescht de etensbak weder, bracht het water naar achteren, willende 't uitgooien, zij zag weder de hongi zooals te voren: één deel was aan 't voorhuis, een ander was aan het huisvenster aan deze, een ander aan de andere zijde, een ander bij het voorhuis weder. De zuster riep weer: Kawĕrai! wat zegt ge er van! Kawĕrai vroeg haar: wat? De zuster zeide: wat? maar een hongi! Kawěrai zeide: zeide tot zijne zuster: Kawěrai's zuster keere langzaam naar voren. Kawĕrai stond op, trok zijn boog met zijne pijlen, liep naar voren, schoot, schoot de afdeeling aan 't voorhuis tot die op was, keerde zich weder naar het huisvenster; dat deel (schoot hij) tot 't op was, keerde tot den (anderen) kant, schoot ze weer weg, liep weer naar het voorhuis en schoot hen tot zij weder op waren, één (slechts) keerde weder, die zeide als de eerste zeide: wij vielen hem aan, maar wij kunnen hem niet (baas). De tehuis geblevenen zeiden: gijlieden dus kunt hem niet (aan), wij daarentegen (wel). Aldus (geschiedde 't) alle dagen: zij vielen hem dagelijks aan, maar hij versloeg hen aldus voortdurend. $Z_{\text {ij }}$ zeiden: vallen wij hem aldus aan, (dan) kunnen wij hem niet dooden! zoeken wij een man die hem gaat bedriegen. Een oud man zeide: ik zal gaan opdat ik hem bedriege, (dat) hij komt en wij hem dooden. Toen ging de oude man, hij ging landwaarts. Kawerrai's zuster ging naar achteren, zij zag landwaarts, zij zag den ouden man, zij riep weer tot haar broeder: een hongi! Maar de oude man zeide: geen hongi, ik uw grootvader, ik ja, gewon uw vader. Kawĕrai riep hem: kom hier! De oude man kwam uit (en) steeg op. Kawerai vroeg hem: jongere grootvader, waarom komt gij? De oude man zeide: ik kom niet om iets, maar zij willen zingen, zij geven dit feesteten aan mij aldus, zeggende: uw 
jongere broer en gij woont hier; zoo ga ik tot u beiden opdat ik goederen vrage van $\mathrm{u}$ beiden, opdat wij dat feesteten eten. En Kawerai zeide: goed, ik zal goederen aan u geven. De oude man zeide: neemt gijlieden ze mee, wij gaan te samen. Maar Kawerrai zeide: gij neemt deze goederen vooruit mede, morgenochtend zullen wij tot u komen. En de oude man zeide: gaat, ik zal komen, ik wacht ulieden, bedrieg mij niet! Kawerrai zeide: wel, ik belieg u niet, wij zullen tot u komen. De oude man zeide: gaat rechtuit, ik zal ze doen eten koken, opdat ik dat meeneme, en ik ulieden wachte. En Kawerrai zeide: goed! gij zult Kawerrai's broeders trom hooren. En Kawěrai beval zijne zuster veel eten te bakken, en zij zeide tot Kawěrai: wij gaan, edoch ik vrees zeer. En Kawerai zeide tot zijn zuster: waarom vreest ge? wij gaan opdat gij dansen zult. En Kawěrai's zuster dacht mee te nemen een deel van haar versierselen, en een deel te laten liggen, maar Kaw rrai zeide: wees niet bang, neem ze alle mede. De zuster gehoorzaamde Kawěrai en nam ze alle mede. Toen gingen zij zeewaarts. De oude man kwam te voren, hij wachtte hen, hij hoorde dat Kawerai's broeder sloeg zijn trom, en de oude man zeide: Kaw rrai en zijn broeder komen al, want de broeder slaat zijn trom al. Zij beiden kwamen bij den ouden man, zij stuurden hem vooruit, 's avonds kwamen zij drieën uit. De oude man riep: klimt op in dit huis! maar Kawěrai wilde niet, hij zeide: Kawerai haat het op te klimmen! Kāwěrai wil hiier beneden slapen. Toen maakten zij een kleine hut. Met zonsondergang zeide Kawerai tot zijne zuster: Kawěrai's zuster versiere (zich). Kawerai's broeder versiere (zich) ook, opdat wij gaan, Kawerrai's zuster danse. En zij drieën zij gingen zij stegen op. (Als er) een wilde zingen overschreeuwde Kawěrai hen zeggende: stil jelui! Kawerai's broeder zinge! Hij zong, zij dansten tot zij ophielden; weer een ander wilde zingen, maar Kawerai overschreeuwde hem weer: stil jelui! Kawěrai's broeder zinge! Alzoo zong Kawerai's broeder alleen tot 't daglicht. ${ }^{1}$ En toen hielden zij op hen aan, zij schreeuwden en beroemden zich. Maar Kawerai sprong op (zoodat de) gebinten braken. Alzoo

1 Een voorzanger vangt aan te zingen, allen zingen hem na en dansen. Bij een volgenden dans zingt meestal een ander weer, d. w. z. verhaalt wat hij zag of wat hem wedervoer op reis, etc. Een aantal trommen en gongs geven de dansmaat aan, terwijl de dans zelf 't meest gelijkt op een gemarkeerden looppas. 
(ging 't) tot den morgen: zij praatten, hij sprong op (zoodat de) gebinten braken. En de zuster zeide tot haar broeder: Kawerai, zij vermoorden ons! En Kawěrai zeide: vreest gij? (Toen 't) reeds groot ( $\mathrm{vol}$ ) dag was, daalden zij af, zij gingen naar beneden naar hun hut. Kawěrai zeide: Kawěrai's zuster en Kawěrai's broeder zijn slaperig, zij slapen. Kawěrai's zuster zat wakende, en zeide: slaapt jelui, laat jelui mij alleen? Kawerai zeide: vreest gij? Willen ze praten, gij zult ons wekken. En als zij zachtjes praatten, wekte zij hen beiden. Kawěrai sprong naar buiten, hakte honden en pisangstammen stuk. Hij zeide tot zijne zuster: (als) Kawerrai's zuster slaperig is, zij slape gerust. Maar zij zeide: ik zou wel willen slapen, maar ik vrees te zeer. Aldus was 't daar tot 's avonds. En Kawerai zeide weder: Kawěrai's zuster versiere (zich); $\mathrm{Zij}_{\mathrm{ij}}$ met Kawěrai's broeder en ik wij gaan weder dansen. En met zonsondergang gingen zij en stegen zij op. Als één weder wilde zingen, overschreeuwde Kawerrai hem weder: stil jelui! Kawerai's broeder alleen zingt! Als de dans uit zijnde, een ander wilde zingen, overschreeuwde hij hem weder: stil jelui! Kawerrai's broeder alleen zingt! Hij alleen zong heel (den nacht) tot den dageraad toe. Toen wilden zij hen weder vermoorden; het dansgezelschap ging uit een, zij vielen op hen beiden aan. Maar zij overmochten hen niet, de broeder hakte één deel, de groote broer hakte één deel van 't huis, zij hakten ze tot den laatste: vrouw, man, kind, allen weg; de kleine oude man, die hen bedrogen had, stond achter den deuringang, hij wilde hen verhinderen, maar zij hakten hem ook, (in een slag door). Dat afgeloopen zijnde. toen daalden zij drieën af, zij keerden weder landwaarts naar hun huis. En toen zij daar waren, kwam de moeders vader tot hen. De zuster wilde weer naar achter gaan, zij zag hem, zij riep weder tot Kawerai: Kawěrai! wat zegt ge er van? Kawerai zeide: wat heeft Kawěrai's zuster? En zij zeide: wat ik heb? maar een hongi! En Kawerai zeide zooals te voren weder, hij zeide: Kawerrai's zuster ga heen langzaam naar voren. En toen stond hij op, trok zijn boog met de pijlen, liep naar achteren. Kawěrai vroeg den grootvader, hij zeide: wie zijt gij? En de grootvader zeide: ik ben uw moeders-vader, ik. Hij riep zijn grootvader, zeggende: kom hier naar voren. En grootvader kwam naar voren, hij herkende hem, hij zeide tot zijn jongeren broeder: dit is onze ware grootvader, dit is moeders-vader. En toen steeg hij op (in huis) en 
zeide tot zijne kleinkinderen: ik (zou) thuis gebleven (zijn) maar alle dagen hoorde ik: hongi's wilden ulieden dagelijks dooden, alzoo wil ik u komen halen. En de oudste kleinzoon zeide: goed grootvader, wij zullen vertrekken. En toen volgde de grootvader hen, zij vertrokken zeewaarts naar hun huis. En zij bleven, tot hij riep zeggende: kampong lieden? wij gaan op hongi. En de kamponglieden maakten al de groote prauwen zeilree, zij roeiden tot er geen overbleef. En een jongeling loog zeggende dat hij ziek was, en hij bleef thuis. Maar zijn hart ging uit naar Kawěrai's zuster, daarom loog hij, hij zeide: ik ben ziek. En hij zond zijn zuster met pinang en tabak naar Kawěrai's zuster.' Maar de zuster was door Kawěrai onderricht, zeggende: gij blijft thuis, als iemand iets voor u zend, zult gij dat niet eten. En zij at ze niet, zij legde dat in de mand, tot haar broeder terugkeerde. Maar zij vergat er van te spreken tot haar broeder. En toen riep haar broeder: Kawěrai's zuster brenge mijn mand hier, dat $\mathrm{jk}$ pinang ete. En de zuster bracht haar hem weder. Kawěrai wilde pinang eten, maar hij zag de pinang en tabak ingepakt, en liggende in de mand, en Kawërai vroeg: Kawerai's zuster! dat pakje ligt in mijn mand? En Kewěrai's zuster zeide: een man die thuis bleef bezit het, hij gaf het, maar ik vergat het $u$ te zeggen. En Kawerai was verheugd, hij zond (de boodschap: 't is) goed, hij wil haar hebben, hij geve dat ik hebbe tien groote prauwen, en veel dingen daarbij te samen. En aldus gaf de man dat alles wat hij vroeg. (Toen) hij dat alles gekregen had, vroeg hij 's mans groote zuster ook. Hij gaf haar ten huwelijk aan Kawerrai, Kawěrai, hij ook, betaalde tien prauwen, tien slaven, vele dingen te samen, gelijk zijn zwager had betaald. En toen bleven zij tot zij weer op hongi gingen, zij vochten tot zij terugkeerden. En Kawěrai riep zijn zuster: Kawěrai's zuster kome hier, zij trekke mijne takken met mijne slaven. ${ }^{2}$ Maar des zusters man wilde dat niet, hij weerhield haar met (zijn) oog, hij wilde niet dat zij tot Kawerrai ging. Maar Kawěrai zond den heelen dag, tot 's avonds. Toen kwam zijn zuster. En Kawerai's zuster baarde een zoon. Zoo kwam het dat Kawerrai haar niet herkende,

1 Het zenden van pinang en tabak is een onder'shandsche liefdesverklaring.

2 Voor iederen gevangen of gedooden slaaf wordt een levende boomtak op do prauw geplaatst, die na thuiskomst aan de zeezijde van 't huis wordt bevestigd. 
hij zeide: dit is Kawěrai's zuster niet. Maar dichtbij komende herkende hij haar, hij zeide: hoe komt Kawerrai’s zuster er zoo slecht uit te zien? En hij nam olie en zalfde haar ('t hoofd), en hij nam een mes, hij sneed hare haren gelijk tot 't genoeg was. En toen verhinderde hij haar, zij bleef bij hem. 't Kind schreide erg tot zij 't niet (meer) konden uithouden, zij zeiden: Kawerai doe zijn zuster tot haar kind gaan, 't schreit te erg, bijna schreit 't zich dood. Maar Kawerai zeide: 't schreie zich maar dood.i Dagelijks maakt hij mijne zuster leelijker, opdat ik haar niet meer zou willen bezitten. En zij bleven tot hij haar ten huwelijk gaf aan een (andere) man, in plaats van haar echtgenoot. En de man die haar trouwde gaf zijn zuster aan Kawerrai, diens jongere broeder trouwde haar. $\mathrm{Nu}$ is 't uit.

\section{Rò pòkai.}

Tawaipai Ròpòkai nia aniosepai Jeripoi na mariapai Jerumi, ria wora marau diramaan Waropenpaisiat. Senbò ajis sentara, tawaipai diramaan siat, tioon siat to senkeis, esi misoi ba. Kausapa ja diramaan siat eja, esiat senbò ja, tioon siat tuter sennè wapai. Tawai bibur eja biur taburan, niè bwabwinpaisiat sentòtò: Ròpòkai miuna! Kausapa ria ja rau, diramaan siat eja, Waropenpaisiat 'senbò eja majis, tioon siat eja tuter wapai to senkeis, esi misoi ba. Ròpòkai bibur eja, biur niè taburanpai. Kausapa ria ja rau, ria na Jeripoi diramaan na Jerumi, wa masasopèsi ria majis, tioon siper $i$ to keis wura. Inèni bibur eja. Raria wura tapèna to Waropenpaisiat senpa ba. Raria siri Ambonai riama na Woisimi rauwipai, riama so Waropenpaisiat, diutan siat, diòtò: witoi miun miat jadjawa i pana? Sentòpan: Ròpòkai, raria wura riama rau tioon amannèpaisiat to amat keis. Inèni Ambonai diòtò: menton bwabwinpěsi iraut $\mathrm{i}$, nani jiramaan Ròpòkai imun $i$, jòne airawi kòta. Sentòne bwabwin esi wèsjeen, riaut i. Ambonai tiòpan so Waropenpaisiat: menmasoi ma menpa ba, wèsjeen, menbabur, jau, imèseri, imasoi, menbabur Nufoori rawanam. Inèni senbabur, Ambonai tuter bwinieempi sunmasoi sunmèseri. Bape bwinieempi kiëmberei i, so diòjò: Ambonai niè těraipai kariria, bië aan, niè těraipai misasabu. Amana Ambonai diòtò: tunmasoi sarědjeu, tunbòru, mantaunjau, tuntenam, mantaunjau, tunmasoi sarědjeu. Inèni Ambonai nianari bwinieempi sanu na niè airawipai abo Ròpòkai 
mitait sanu, nianari sunnè aniopai kòta na airawi. Inèni kausapa Ambonai ria kiutu airabwan, kioor rěwuki, kiutu parai, tiam si na aniopai to pau besiri, dimis bwinieempi kioor sasa, kioor kambo nianari karumaas, niunum rěwukipaisi to simaas, sunritamaan Ròpòkai. Inèni Ròpòkai riama rau, ria babari aipaisi sitawa, ria babari anampaisi sitababari kòta. Ambonai bwinieempi sanu sunradjawa i. Ambonai bwinieempi siëis, diòtò: raria nini ma tuntanè? nani tunbòru kòta te? Sawani diòtò: tunmasoi sarědjeu, mutait pënai! nunari karumaas, nunum rěwukipaisi to simaas. Inèni Ròpòkai riama raủ, biata na atèpai, diò biaan sòrèpai, diò tioon aniopai tuter sanu, bape Ambonai dipai tuter rěwukipai bemaas, kiai si so Ròpòkai sòrèpai, bia sòrepai ja, kiai airabwan so sòrèpai, biubu karumaas so sòrèpai, kioor rěwuki ja, kiai si so sòrèpai ja, kiai airabwan eja, biubu karumaas eja, kiai rěwuki eja so sòrèpai, to tawaipai tiawa, diòni to miriëran to biòru. Inèni kioor sumbeer, tamaan, ria awaab, kiutu rupai, pir $\mathrm{i}$ wèsje, tiòta niè teraipai be rabwiban. Inèni Ambonai kioor tawaipai niè těraipai kioor si are, pir si ariri kàpar to mennau. Inèni tiòpan so bwinieempi: nani bië kàpar tunrinda rau so sinjamusiat na Nufoori. Inèni Ambonai nianari riwàni niè těraipai, diteen $\mathrm{i} \mathrm{ja}$, nianari na airawi niè těrai, kariria niei. Inèni bwinieempi diòtò : jò, sa kuriria pa ikemberei au pa, kabò isera ma buteen ja. Inèni sunrena to kausapa, suntando, bwinieempi sijoor sunnè anioraròpai diteen, so pigangèna pau, pi besasjeen wura: nora, tariwan, andio besasjeen, paarwasi, mangkò, pisjajabrawan, pi mirandin, sawani diòne si so bwinieempi, mirandin bwinieempi. Inèni bwinieempi sanèwèsjeen sawani, diòtò: jò, sa kuriria pa irama ba pa, bape inèni isajoor au buteen pa raiwain. Siènendik sawani. Inèni sawani tiòpan so bwinieempi : musoi, sujoor ira re. Inèni Ambonai ria re, diòtabia, tiòpan: wè! buekàpar! abema japai so bwabwinè tamaanisiat na Nufoori! Inèni tawaipai niè těrai bië kàpar, ria rau, diboi. Tiòpan eja: pisjaanpaï pau! pimunapai pau! tiòpan: thee,gura, pisaserapai wura si na na kàpar! Inèni tiòpan: wapai dipai so Nufoori! ma sunsa kàparpai, sunrapai so Nufoori. Inèni sunda re so niònisiat, bwabwinpai tamaani sijoor ririn aantumbwabwinpai, diòtò: tei kioor au marau pa? Inèni aantumbwabwinpai tiòpan piwura so tamaani. Tamaani sentòtò: au ma kumběrei $\mathrm{i}$, buòjò: sa kiriria, bape sujoor! buteen! mèmu pisasera pau! Ma aantumbwabwinpai diòtò : saněpai miat pana, apa ikabio pana. 
Inèni Ambonai diriën niònisiat, kioor siat eja so Waropen. Kioor siat mare, inèni Ambonai kioor tawaipai sinapaisi, bioob si ariri anio bebareripaisi. Inèni siaaw: aniosepai! diëna te? mensanèwesjeen mentara? Inèni aniose miasaar wura, sentòtò : amansanèwèsjeen amantara. Inèni sentenam wura ja, tawai sinapaisi senbesinjontu wura. Ambonai tiòpan : seeri babòrupai riama! anampaisi sipau, anam tawapaisi sinei wura!

Inèni Waropenpaisiat sentariori : kajobipaisi, kojaripaisi, diòsunpaisi, setaan si ba, senmateit si, so si tapè tawaipai, sentò sentaan si, sennè terrai bekapapor, sendut si na senbarami kòta ba, tannunum si, siseir so si ba, senmateitě si wura. Ambonai diòne sendut buwai Nufoori: marariapaisiat sentòn sampaar na sendaimi, sendoi so siat, sennanari karures katu na ampeerpai, senmarandinč si, senmaji sendut si tuter mararia sendoi swapai siat, so sennè buwai senkoor na Nufoori mare pa.

Ròpòkai niè airorapai kioor i marau, dintoür siat, kioor i kòta marau tiò dimun Ambonai bwinieempi sanu. Bape Ambonai miun tawaipai, biòru, airorapai biati. Ambonai Waropenpai, sinjontu wàtanpai, tapunisiat senpir $\mathrm{i}$, sentòne $\mathrm{i}$ be aimamuna pidiaar siat senmun siat, mamò senkir i amamò sopè esipai senbekapor, mantaunsiat ma pibai.

\section{Vertaling:}

De slang Ròpòkai wonende in de kampong Jeripoi, aan de beek(rivier) Jerumi, ging voortdurend naar buiten, loerende op de Waropeners. (Als) zij stroomopwaarts roeiden om (sago) te kloppen, loerde de slang op hen, slokte hen allen in, niet één bleef over. Den volgenden morgen weder loerde hij weder, eenigen roeiden weer, hij slokte hen in met hun prauw. De slang vertrok weder blazende zijn oorlogsschelp, zijne vrouwen zeiden: Ròpòkai doodde! Den volgenden morgen ging hij weer uit, beloerende hen weder; de Waropeners die weder stroomopwaarts roeiden, slokte hij weder op met hun prauw, tot ze allen op waren, niet een bleef over. Ròpòkai vertrok weder, blazende zijn schelphoorn. Den volgenden morgen ging hij weder uit, ging van Jeripoi, loeren aan de Jerumi, een prauw vol volk ging stroomopwaarts, hij slikte die geheel op tot alles op was. Toen ging hij weer weg. (Dat ging) alle dagen $z o o$, tot de Waropeners 't niet meer konden (uithouden). Op een 
dag kwam Ambonai van de bronnen der Woisimi, hij kwam tot de Waropeners, hij vroeg hen: zeggende: wat vermoort jelui naar dat ik gehoord heb? Zij zeiden: Ròpòkai! elken dag komt hij uit en slikt de onzen in tot wij op zijn. Toen zeide Ambonai: geeft mij een vrouw ten huwelijk, (dan) zal ik op Ròpòkai loeren (en) dooden, ik geef ook medicijnen. $\mathrm{Zij}$ gaven hem een goede vrouw, en hij trouwde haar. Ambonai zeide tot de Waropeners: als gij blijft kan het niet, welaan, vertrekt, ik, ik alleen, ik blijf, gaat gijlieden naar Nufoor in zee. Toen vertrokken zij, Ambonai met zijne vrouw, zijbeiden bleven alleen. Maar de vrouw haatte hem, want zij zeide: Ambonai's lichaam is slecht, hij heeft schurft, zijn lijf (te weten: de huid) is gescheurd (bedoeld is: de groeven der scabies). Doch Ambonai zeide: wij blijven maar, wij beiden sterven, ik zelf (d.w. z.: z. a. ik wil), wij leven, ik zelf en gij blijven maar. Vervolgens bewerkte Ambonai zijne vrouw en hem met zijn medicijn, opdat Ròpòkai henbeiden vreezen zou; hij bewerkte hunbeider huis ook met zijn medicijn. Toen, den volgenden morgen, ging Ambonai boomstukken hakken, hij haalde steenen, hakte ryzophoren-hout, stapelde ze op in zijn huis tot' er zeer veel was; hij zond zijne vrouw die haalde bamboe-wāter-vaten; zij haalde water, maakte heet water, brandde de steenen tot zij heet waren, zij loerden op Ròpòkai. Toen kwam Ròpòkoi uit, ging dringende (dat de) boomen vielen, drong ook de sagoboomen omver. Ambonai (met) zijne vrouw hoorde 't, Ambonai's vrouw huilde, zeggende: hoe zal dat heden (met) ons beiden? De man zeide: wijbeiden blijven maar, vrees niet! maak heet water, brand steenen tot zij heet (zijn). Vervolgens kwam Ròpòkai uit, en lag aan de trap, deed zijn bek open, het huis met hunbeiden willende inslikken, maar Ambonai liep hard met heete steenen, wierp ze in Ròpòkai's bek, die deed den mond weer open, hij gooide boomstukken in den bek, stortte verder heetwater er in, wierp weder steenen in den bek tot de slang viel; hij gaf haar tot zy (zich) kromde (van de pijn) en stierf. Toen nam hij kapmes en bijl, ging naar beneden, hakte den kop af, legde dien alleen, hakte zijn lijf aan mooten. Vervolgens nam Ambonai het slangenlijf, hij bracht het landwaarts, legde het uit totdat het voldoende was voor een vaartuig. Toen zeide hij tot zijne vrouw: 't zal een schip worden (waarmede) wij zeewaarts gaan naar uwe moeder (en) de haren op Nufoor. Daarna deed Ambonai zijn (eigen) lijf ver- 
anderen dat 't weder goed (werd), hij deed met zijn medicijn zijn slecht lijf verdwijnen. Toen zeide zijne vrouw: daar gij zoo slecht (n.l. leelijk) waart, heb ik u gehaat, nu zie ik dat gij weder mooi zijt. Toen sliepen zijbeiden tot den morgen. $\mathrm{Zij}$ ontwaakten, de vrouw zag: hun kamer was fraai, want (er waren) veel bezittingen, alles mooie dingen: kussens, dekens, fraaie slaapmatten, borden, kopjes, gouden oorbellen, versierselen. De man gaf ze aan zijne vrouw, hij versierde zijne vrouw. Toen hield de vrouw van haar man, zeggende: ja, toen gij leelijk waart kwam ik niet, maar daarna zie ik gij zijt veel schooner. $\mathrm{Z}_{\mathrm{ij}}$ prees haar man. Toen zeide de man tot zijne vrouw: blijf hier; zie, ik ga landwaarts. Toen ging Ambonai landwaarts, hij stampte met den voet, zeggende: hé, word schip! opdat ik vare tot dezer vrouws vader (en) de haren te Nufoor. Toen werd het slangenlijf een schip, 't ging naar zee, 't dreef. Hij zeide weder: (er zij) véél eten! véél varkensvleesch! hij zeide: thee, suiker, van alles zij in 't schip! Vervolgens zeide hij: de prauw vare naar Nufoor! en zijbeiden stegen in 't schip, zij gingen naar Nufoor. Toen zij landwaarts gingen naar de schounouders, herkende de vrouwsvader zijne dochter, hij zeide: wie heeft u zeewaarts gebracht? Toen vertelde de dochter alles aan haar vader. De vader (en de zijnen) zeiden: gij, wel gij haatte hem, gij zeidet ja, hij is slecht (leelijk), maar zie! gij zijt goed af! gij bezit veel van alles. En de dochter zeide: ik hield van ulieden, daarom heb ik gesproken.

Daarna bracht Ambonai zijne schoonouders en de hunnen weder terug naar Waropen. Hij bracht ze binnen, toen nam Ambonai de beenderen der slang, deelde ze overeenkomstig de ledige huizen. Daarna riep hij: kamponglieden, slaapt gij? wilt gijlieden sago kloppen? Daarop riep de geheele kampong, zeggende: wij willen sago kloppen! Toen leefden zij allen weder, de slangenbeenderen werden allen menschen. Ambonai zeide: een nieuw sagobosch kome! sago in menigte! al de oude sago verga!

Daarna beschouwden de Waropeners als onrein: inktvisschen, palingen en zeepalingen, zij eten ze niet, zijn er bang voor, omdat zij als slangen zijn; zij zeggen (als) zij ze eten, (dat) hun lichaam puistjes (eczeem) krijgt, zij houden ze ook niet in de hand, willen ze niet ruiken (als) wij ze eten, zij vreezen ze allen. Ambonai liet ze de adat Nufoor houden: den kinderen geven zij schelpenringen aan de voeten, (als) zij voor hen zingen 
maken zij schepen van sagobladstelen, zij versieren ze, dansende, houden zij ze vast met de kinderen waarvoor zij zingen, want hun adat haalden zij van Nufoor landwaarts.

Ròpòkai's slaghout (stok) nam hij mee naar buiten. Daarmee had hij hen bedreigd, hij nam het ook mede zeewaarts (toen) hij Ambonai en zijne vrouw beiden, wilde dooden, maar Ambonai doodde de slang; deze stierf, zijn slaghout (stok) bleef liggen. Ambonai de Waropener, werkelijk een man (in onderscheiding van dien van het verhaal) en zijn nakomelingen bewaarden dien; zij houden hem als houten wapen dat afstoot die hen bevechten. Daarom zwaaien zij hem opdat de tegenstanders gewond worden, maar zijzelven niet.

\section{Make.}

Makepai tiara siepar niè rebomakaipa, diòně $\mathrm{i}$ be su, abe tiara ma minawar, abema inaarěpaisiat sentò so i. Saar tiara ja, tapèna niè supai minawar wora, tiòpan: itara, inè sunè minawar, abema inaarěpaisiat sentò so jau. To rariapèsi ja tiara ja, inaarpèsi riama so $\mathrm{i}$. Inèni makepai tiòpan so inaarěpai, diòtò: ruri adiapèsi, nani buonsajoor jau. Inèni inaarpai riuri adiapai to bibiaar. Inèni makepai kiai mitauni so adiapai, bape diaan ba, piòtètap adiapai, kiòpas ari, misoi na wòrira, adia diaan i ba. Bwabwinpèsi ja riuri adiapai ja. Inèni makepai kiai $i$ ja arau so adiapai, bape tiètap $\mathrm{i}$ ja ari, misoi na wòrira, adiapai diaan $\mathrm{i}$ ba. Inaarěpèsi ja ria ja ma, riuri adiapai eja, makepai kiai ja rau, bape kiòpas ja mare, adia diaan $\mathrm{i}$ ba. Inèni inaarpèsi ditateen mò riama, makepai dimis $\mathrm{i}$ riuri adiapai. Inèni inaarępai riuri adiapai to bibiaar. Inèni makepai kiai arau, înèni adia diaan $\mathrm{i}$ to keis, to dinbòru. Inèni riwàni biësinjontu, kiòpas are, misasoi. Makepai niè tumpai bië kasumba-djawa sibebrawan, paarwasi wàtan, pisasera wura. Inèni makepai diòtò: woma, pi jani jawi sasera miat $\mathrm{pa}$, inèni inè au pena. Inèni siòkoor $\mathrm{i}$, sunbabur, sunbabur so sunè aniopai. Inèni benaibabopai (repoorpai) riama, diòjò diatar makepai, abema riaut bwabwinpai, bape makepai miajar ba, diatar repoorpai. Makepai tuter bwinieempi sunmasoi na Jeripoi.

Tapènina Waropenpaisiat sentariori, sennèwori: makepai, repoorpai, sentaan si ba, sensajoor si kòta ba, sentò sa pidadiaar siat, sentòjò sensajoorě si nani esi biòru ja. 


\section{Vertaling :}

Een kakatoe klopte sago, zette haar kuif op, deed die lijken op een (bamboe) haarkam (een vier of vijftandige vork), versierd met wapperende lapjes gekleurd katoen, opdat, (als) hij sago klopte, (die) zou wapperen, opdat de weduwen hem zouden begeeren. Den volgenden dag klopte hij weder sago, zoodat zijn kam (c. a.) aldoor wapperde; hij zeide: ik klop sago mijn kam wappert, opdat de weduwen mij zullen begeeren. Op een dag klopte hij weder, eene weduwe kwam tot hem. Toen zeide de kakatoe tot de weduwe, zeggende: stook vuur, let dan op mij. Toen stookte de weduwe vuur tot het vlamde. Toen wierp de kakatoe zichzelf in 't vuur, maar het at (verteerde) hem niet, hij schudde het vuur af, sprong er uit, zat er buiten, het vuur at hem niet. Weder stookte een vrouw vuur. Toen wierp de kakatoe zich weder in 't vuur, maar hij schudde zich weder uit, zat er buiten, het vuur verteerde hem niet. Een andere weduwe kwam weer tot hem, zij stookte weder vuur. De kakatoe wierp zich er weder in, maar sprong er weder uit, het vuur verteerde hem niet. Toen kwam een zéér mooie weduwe tot hem. De kakatoe zond haar om vuur te stoken. Toen stookte de weduwe vuur tot het vlamde. Toen de kakatoe zich er in wierp, toen verteerde het vuur hem geheel, tot hij stierf. Toen veranderde hij in een mensch, sprong er uit, en zette zich. De vederen van de kakatoe werden slendangs, werden goud, borden (echte), en allerlei begeerlijke dingen. Toen zeide de Kakatoe (nu als mensch draagt hij ook dezen naam): kom! (met) deze dingen zoek ik ulieden aldus te lokken, vervolgens heb ik u. Toen volgde zij hem, zijbeiden gingen heen, zij gingen heen naar hun huis. Toen kwam een die boven woont, ${ }^{1}$ die wilde Kakatoe wegjagen, opdat hij de vrouw zou trouwen, maar Kakatoe wilde niet, hij verjoeg het buideldier. Kakatoe en zijn vrouw wonen te Jeripoi.

Daarom vermijden en schuwen de Waropeners als onrein de

1 "die boven woont", een schuilnaam, voor een „repoor": boombuideldier. De verteller heet: Repoor, en mag volgens Papoesche adat, zijn eigen naam niet noemen. De man is een mijner catechisanten, waarom ik hem lachend aauzag, en vroeg: hoe heet dat beest? Lachend antwoordde hij : repoor. 't Is mede om deze adat dat geen Papoea zijn ouden naam wil blijven dragen, als hij Christen wordt.

Dl. 70 . 
kakatoe en het boombuideldier; zij eten ze niet, kijken er ook niet naar, zeggen : zij stooten hen af (dat wil zeggen : in letterlijken zin), zij zeggen als zij ze zien, zal er een (van hen) sterven.

A anteekening. Uit dit stukje blijkt dat: marau, arau, rau, naar zee, zeewaarts, naar buiten in den zin van zeewaarts, en mare, are, re, naar land, landwaarts, naar binnen, ook wordt wordt gebruikt als ergens in, en uit gaan. Z. a. in vuur.

\section{Serapasamai.}

Serapasamai, Měňwasi nina, bwinieempi sanòpai Imbarasei. Imbarasei diòsa. Sanèpai baba katu, niòni sioorbedjoor i to wòroi katu, diòn' sanè piaat kabui. Tapuni tuter bwinieempi sunda sunroban anam, suntara so $i$, Serapasamai ria aduata, kioor wangop siri, atobin siri, diana pisei sura, amor sura, ajapai sinjontu siri, kioor si arau, Serapasamai tamaani sinjani suntara, rawiniena sunbabur ma. Kausapa Serapasamai tamaani tiara, aantumpai ria aduata, diana pimuna, diana aja, amor, rawiniena kioor si so anio, tamaani sinjani suntara sunron' babur ma. Inèni marariapai sinjani misoi tuter $i$, tapuni sisinbedjoor sanu na pendewai, misoi to misibiba katu. Serapasamai tamaani tiòpan so aantumpai: itara anampèsi, au rua aduata. Inèni ria kioor wangop siri, atobin siri, ria diana pisei sura, amor sura, ajapai sinjontu siri, rawiniena kioor si arau so aniopai, tamaani sinjani sunròn'koor anampaisi kòta marau. Kausapa ja, senda ja', tamaani sinjani suntara, aantumpai ria aduata. Raria siri miun pisei sura, amor sura, aja sinjontu siri, rawiniena kioor si arau so aniopai, tamaani sinjani sunròn'koor anampai marau. Kausapa wura tapèna. Inèni aantumpai misibiba sentòně aantum, sinjani, sunsubi wura. Inèni marariapai bibarara to, inèni tapuni tiòpan so aantumpai: tanda ja, tanroban anampèsi ja, tantara $\mathrm{i}$ so marariapai niè sampaar-aipai diòtu. Inèni tamaani senda, senroban anampèsi, tamaani sinjani suntara, aantumpai ria aduata, kioor wangop siri, atobin siri, diana ajapaisi sinjontu siri, pisei sura, amor sura. Inèni rawiniena kioor si arau, tamaani sinjani sunròn'dama rau, sunkoor anampaisi ma. Kausapa wura tapèna wora: tamaani sinjani suntara, aantumpai ria aduata, diana piseipaisi sinjontu siri, amorpaisi sinjontu siri, ajapaisi sinjontu mònu. Kausapa ria ja, tamaani diòtò: tuòpi! rua ma sujoor au, 
so piesi miun au pé! Ria to rawiniena, bibur ma, miun pimunapai to baba besiri, tamaani tiara anampai to baba besiri. Kausapa ria ja, miun eja tapèna, tamaani sinjani suntara sunkoor anampai marau eja. Kausapa aantumpai ria ja, tamaani direr i, diòtò: tuòpi! rua ma sujoor au, so piësi miun au pĕ, buòru berusua mararianè pĕ, biba ba bo. Amana aantumpai didjawa $\mathrm{ba}$, miajar ria wenasja. Inèni tamaani diòtò: pimuna nè biba tó, roipaisi sikiòtarě to. Amana aantumpaī diòtò : pau ba rami! esasi ja! Kausapa wura ria ja, to raria pèsi ria ja, ria ja marau, piòta, tiòpan so tamaani: inè těrainè piòta! tiòpan so sinjani: awini! nunari karumaaspèsi so jau, jisoiba, ibisi beja. Ma sioib to, raria worawiniëna tiòpan so tamaani: joibòru! Tamaani diòtò: wò ma! itòpan so au, jòjò: rua ma sujoor au! bape budjawa ba! Itòpan so au: tundoi pa na nièsi ja, bape budjawa ba, buòtò rò! buòru berusua mararianè! Inèni Serapasamai biòru, rawiniëna senkoor sensěra i, sentòn' so i sòri diòsa rupai rebosinapai, kausapa, rawiniëna tamaani kioor kambopai siaar i so i. Inèni biata to niè terraipai niëi wura. Inèni tamaani ria re, sira $\mathrm{i}$, kioor rudirpai. kioor $\mathrm{i}$ arau, pir i na niè andio raròpai. Kausapa inaarpai biai aantumpai, kioor sawani rudirpai, pisaan $\mathrm{i}$ na ròtanpai, kisjees kòta ròtanpai sorèpai, kiababa i kioor i, sunda sunmasoibedjoor tawanpai. Kausapa sunda ja, kioor sawani rupai ja, rawiniëna sunbabur arau. Kausapa niòni tiòpan so rewapai: buai marariapai, munda re, munmasoibedjoor tawanpai, so ajapaisi sirama, siaan i. Biai aantumpai, sunda, rawiniëna sunda ja rau, kausapa sunda ja, biai aantumpai, kioor sawani rupai, kiababa i. Inèni sunda re, ma marariapai tamaani, Serapasamai, ria ma na suruga, sia jis, misoi na tawanrauipai, misoi, diaan tawanpaisi, sitawa wora awaab. Inaaripai diòtò: aja ramòpaisi siaan inè marariapai niè tawanpaisi beja! tòkato ma sikeis! Rawiniëna sunbabur, kausapa sunda ja re, tamaan ria ja ma, misoi na tawan-raui, kiai tawanbopèsasi awaab so aantumpai. Amamò aantumpai dinasa tamaani, amamò sieis tòrò sinjani pia i ba. Rawiniëna sunbabur, kausapa sunda ja. Marariapai sinjani siaaw madjawipai, diòtò : ruama abe buai mararianè! Inèni senda. Serapasamai ria ja ma misoi na tawan-rauipai kiai aibosi ja awaab so aantumpai. Aantumpai sieis eja so dinasa tamaani, diòtò: awini! jai ni niai ninèsa! Amana sinjani diòtò: tamaanmui rupai ipasaan i ròtan nè. Amana aantumpai sieis to kariria besiri, sinjakatuni diòn' 
mojar i ba, tiòpan so babai, diòtò: babai! aantumnè sieis to ipa ba, mèmu awatanè! Sinjani diòtò : sieis sasera tamaani pana. Inèni tamaani biaar katu mèsu, kiròtu tawan-samupèsi, kiai i so aantumpai. Ma sinjani, sijoor samupai, diòtò: aja ramòpai mieir marariapai niè tawanpai beja! Inèni rawiniena senda rau, kausapai inaarpai siaaw madjawipai eja, senda ja re, sinjakatu biai marariapai, sinjani kioor sawaanrupai. Marariapai sieis eja, sinjakatu diòtò: awata bekariria nè siei beja! Inèni tamaani Serapasamai didjawa sinjakatuni djeuso aantumpai, saněpai i, biaar awaab, kiròtu tawan-samupèsi, dinbiara. Inèni aantumpai sijoor aji so $\mathrm{i}$, tiòpan so sinjani, diòtò: jai nia wani! Amana sinjani diòtò: pibai! tamaanmu rupai ikoor i nè jani ma, sinjontu bewèsje beawia anina. Amana tamaani biaar awaab, riama so bwinieempi, tiòpan so bwinieempi: kuai pi jani, buniwar i, janina. Amana bwinieempi diòtò: inda! buawia jau! Sawani diòtò: pibai! janina! Inèni bwinieempi kioor rupai are, diniwar $i$, kiai pimandapaisi. Inèni senda rau, bwinieempi ria rau, tiòpan so niònisanu, diòtò: munkai pimandapaisi, aantummui amandama rau nè. Inèni Serapasamai sinjani, tamaani sunkai sunnè pimandapaisi. Serapasamai sinjani tiòpan: wò! ma! pi jani itòpan so au, jò jò : rua re, musoi na tawanpai, nani riama rau! Inèni Serapasamai ria rau, misoi na kambopai reponpai. Diru sentena sawani tiòpan so bwinieempi: nani sentutan au te, tuòpan penai, musoi na rarò nè wenasja, ruaar i so siat pennai! Tapèna misoi na anio rarò diru at. Raria wura bwabwinpaisiat sensaaw $i$ abo sentutan $i$, bape riama ba, sensaaw $i$ wora, bape riaar i ba. Sensaaw i tawana to pia ba. Inèni siubi, riaar i so bwabwinpaisiat na repuipai. Serapasamai misoi na kambopai diduaat siat. Inèni didjawa bwabwinpaisiat sentutan bwinieempi, setòtò: isopi! diru sawamui munrena pa, tanè niè teraipai? riesa te? Bape riaare seira ba. Sentutan i tawana to pia ba, sentutan i ja: isòpi! diru munrena tianè? so niè těrai babòrupai, riesa te? Inèni bwinieempi tiòpan, diòtò: riesa ma! Serapasamai didjawa, mimaja, kisjo, diòtò: bwabwinpai au ma! janiau au, ma budjawa ba! nani ira, ma ibabur aantummui manu! Ma kioor apa, atobini, biaar manana na reponpai ma bibur. Ma bwinieempi ria pon, sijoor sasera i na kambopai, bape rin $\mathrm{i}$ ba, diòtò: sinjontupai ma, biaare bibur to! mimaja. Inèni biai aantumpai, sunrusar i, sieis, diòjò: "sawasonei au! bwinda toi ?» Amamo bwisaarpèsi diramaan i (bwisaar sanopai Indòki) 
diòto: hé, sueis so? tanta tantòně ma mun djè woraupai te? mun djè seerpaiè? amat rin $\mathrm{i}$ ba pana! amat amantòne ma mentatuba miat pa nè? Wò! ma! kuoor marariapai ma buaum i na tamaani anam-diaanpai, kuoor marariapai ma buitaum i! Inèni sinjani diòne sampaarpèsi so bwisaarpai, diòtò: tuòpan è mararia nè tamaani ria tapa? Bwisaarpai diòtò: katuena ria na raanpai niani. Inèni-sinjani sunda, siëis eja: "sawasonei! au bwinda toi? sawai i Serapasamai, au rua toi?» Inèni bwisaarpai Indòki siodiai: jè! tanta tantòne ma mentatuba miat pana? sueis so? kuoor marariapai ma, diaan tamaani anam, diaan tamuanè abo buitaum i. Inèni sinjani diòne sampaarpèsi, pitapoipèsi, dinbait $i$, diòtò: tuòpan raanpai so jau! Bwisaarpai diòtò : raanpai aniani, katuena pi riamatu pa. Inèni sinjani biai aantumpai, sunda, sunda sieis i ja: "Sawapai Serapasamai! rua toi? Ario matombun! mundira jau ira na toi jò?» Indòki diramaan i ja, diòtò: sueis so? tanta tantawi au è? sueis pěnai! kuoor marariapai nè, buaum i na tamaani anam, diaanè tamuan nè. Inèni sinjani kioor marariapai, diaum i. Inèni diòne sampaarpèsi, ramoor bepautu, diòne so bwisaarpai. diòtò: tuòpanè marariapai tamaani ria tapa? Bwisaarpai diòtò: arapai ria na raanpai anani ma tu. Inèni sinjani biaar ria rusar sawani, siëis: "Sawa Serapasamai! au rua toi jò ba o?» Riama so Indòki niè aniopai, sawani kòta misoi na aniopai. Bwisaar siaaw i: sueis penai! ruama! sawamu anini! arapai misoi anionè! Inèni sieis! Senmasoi, to diru, Serapasama tiòpan so bwinieempi Imbarasei, tiòpan so i, diòtò: diru ma ibò, jadiaat, ruri tawan adiapai, so biòru pĕ, munrena to irama. Adiapai biòru munrena sarědjeu, nani irama ikoor maas, tanduri na i, bape munda so bwisaar pěnai! Bape bwabwinpai diëna, adiapai biòru, ma dinuanum beja, sijoor Indòki diena, ma aibupai sanu sunbenataar, ma bwabwinpai diòjò: adia pi na! Ma kioor kakibari, tiob risu aibupai. Bwisaarpai dinanaar diòtò: ajiji! aibupai nè! kuoor i matupai! Buò rua rau pěnai! rua rau so tamaanmu sinjamui sanu pěnai! Ma bwabwinbai misoi to sawani riama; tiòpan so i, diòtò : bwisaarpai aibupai ni, itob risu i pa! Sawani tiòpan: wò! ma! itòpan so au: rua so bwisaar wa penai! bape budjawa ba! Nani tanda rau ba to! tanměnau pena! tanna na suruga wura! tanda so utan ba to! Inèni bwabwinpai misoi, sieis raria boreipaisi, sieis tamani sinjani sanu. Serapasamai tamaani sinjani sanu sundut pimanda so aantumpai ja. Bwabwinpai tamaani sinjani kòta sendut pimanda wura. 
Tapènina sentòpan: senbòru, senda so suruga, sensoberei ja, bape so Imbarasei kiòrusaar sawani ba, so tiob risu Indòki aibupai sanu, tapènina senmenau, Indòki bedjoor siat: senbòru ma senriwan ba to, bape sennei be siri na suruga.

\section{Vertaling.}

Serapasamai, dat is een Měněwaarer, zijn vrouws naam is Imbarasei. Imbarasei werd zwanger (voor de eerste maal). Toen haar buik een beetje groot werd, sloot haar schoonmoeder haar op voor eenigen tijd, omzwachtelde haar (buik) met een (mans-) schaamtegordel. ${ }^{1}$ De grootvader (in spé nog n.l.) met zijne vrouw, gingen beiden een sagoboom vellen, zij klopten sago voor hem (n.l. om te "aanbedjoor" d. i. te eten tot des kinds heil, om te voorkomen dat leed het zou genaken), Serapasamai ging op jacht; hij nam één varkenspijl, één pijltje, hij schoot (pijlde) tien varkens, tien kangoeroes, twintig vogels. Hij bracht ze uit, Serapasamai's vader en moeder klopten sago, 's avonds keerden zij terug. Den volgenden morgen klopte Serapasamai's vader sago, de zoon ging jagen, schoot varkens, vogels, kangoeroes; 's avonds bracht hij ze naar huis, vader (en) moeder klopten sago, zij beiden deden 't (thuis) komen. Vervolgens zat de moeder met het kind (toen het kind geboren was) scheidde de grootmoeder beiden af met een wand, waar het (kind) bleef tot het wat grooter (ouder) was. ${ }^{2}$ Serapasamai's vader zeide tot zijn zoon: ik klop sago, ga gij jagen. Toen ging hij, medenemende één varkenspijl en éên pijltje. Hij ging, schoot tien varkens, tien kangoeroes, twintig vogels; 's avonds bracht hij ze naar huis, zijn vader en moeder deden ook de sago zeewaarts brengen. 's Morgens weer gingen zij weder, vader moeder klopten sago, de zoon ging jagen. Eén dag doodde hij: tien varkens, tien kangoeroes, twintig vogels, 's avonds bracht hij ze naar huis, vader moeder deden de sago zeewaarts brengen. Alle morgen (ging) 't zoo. Toen het kind groot genoeg was, deed men 't kind en de moeder uit hun afzondering komen. Vervolgens werd 't kind grooter; toen, zeide de grootvader tot zijn zoon laten wij weder gaan, laten wij weder een sagoboom vellen, wij

1 Opdat het kind een jongen zoude zijn.

$2 \mathrm{Bij}$ de geboorte van een kind is de vader niet thuis, en ziet het in den eersten tijd ook niet. 
kloppen dien voor het breken van des kinds schelpen-enkelring. ${ }^{1}$ Toen gingen zij, velden een sagoboom, vader en moeder klopten sago, de zoon ging jagen, nam mede: één varkenspijl, één klein pijltje, hij schoot twintig vogels, tien varkens, tien kangoeroes. Des avonds bracht hij ze, vader en moeder kwamen ook uit, zij brachten de sago mede. Alle morgens ging 't aldus door: vader en moeder klopten sago, de zoon ging op jacht, hij schoot twintig varkens, twintig kangoeroes, veertig vogels. 's Morgens ging hij weder; zijn vader zeide: tuoppi! ga, maar pas op dat niet iets u schade! Hij ging tot den avond, hij kwam terug, hij had gedood zéér veel varkens; vader had geklopt zéér veel sago. 's Morgens ging hij weder, doodde weder aldus; vader en moeder zij beiden klopten sago, zij brachten de sago weder uit. 's Morgens ging de zoon weder; de vader waarschuwde hem, zeggende: tuoppi! ga, maar pas op dat niet iets u schade en gij sterft, verlatende uw kind dat nog niet groot is! Edoch de zoon luisterde niet, hij wilde toch maar gaan. Toen zeide de vader: wij hebben veel wild reeds, de droogrekken (om te rooken n.l.) zijn reeds vol. Edoch de zoon zeide: niet veel nog! meer nog! Elken morgen ging hij weder, tot hij op een dag weder ging, (en) hij ziek terug kwam. Hij zeide tot zijn vader: mijn lichaam is ziek! hij zeide tot zijne moeder: moeder! maak warm water voor mij, ik baad (mij er mee), ik heb erg de koorts! Toen hij gebaad had, in den namiddag zeide hij tot zijn vader: ik sterf! Zijn vader zeide: hè! en ik sprak tot je, zeggende: gij gaat, maar pas op! maar gij luisterdet niet! Ik zeide tot je: laten wij zingen met wat wij hebben, maar gij luisterdet niet, gij zeidet: waarom! Nu sterft gij verlatende uw kind. Toen Serapasamai gestorven (was) begroeven zij hem 's avonds, zij maakten voor hem een bamboe-buis die stond op zijn hoofd op 't voorhoofd. ${ }^{2}$ 's Morgens en 's avonds nam de vader water en schonk het er in (n.l. in de bamboe-buis die boven 't graf uitstak). Vervolgens lag hij tot zijn vleesch geheel verteerd was. Toen ging zijn vader landwaarts, hij groef hem op, nam den schedel, bracht hem zeewaarts, plaatste hem in zijn slaapmat. 's Morgens droeg de weduwe haar kind op den rug, nam haars mans schedel, deed hem in een zak, bond ook

' Als 't kind gaat loopen krijgt 't op een daartoe gegeven dansfeest schelpen enkelringen aan, die later, als zij te nauw worden, feestelijk worden stukgemaakt.

? Zie de aanteekeningen aan het einde. 
des zaks mond (dicht); zij hing hem aan haar schouder, zij nam hem mee; beiden (moeder en kind n.l.) bleven op de tawan $^{1}$ passen. Volgenden morgen gingen zijbeiden weder; zij nam haars mans hoofd weder mede, 's avonds gingen zij weer naar buiten. 's Morgens zeide de schoonvader tot de schoondochter: draagt den jongen, gaat gijbeiden landwaarts, blijft passen op de tawanvruchten, want de vogels komen, zij eten die. $\mathrm{Zij}$ nam 't kind op den rug, zijbeiden gingen, 's avonds gingen zij weder zeewaarts, 's morgens gingen zij weder, zij nam 't hoofd haars mans mede, zij hing 't aan haar schouder. Toen gingen zij landwaarts, en des kinds vader, Serapasamai, kwam uit het verblijf der dooden, hij klom op, zat in den tawan(boom) top; hij zat, hij at tawanvruchten, die vielen voortdurend naar omlaag. De weduwe zeide: die verwenschte vogels! zij eten mijns kinds tawanvruchten al te erg! welhaast zijn ze op! 's Avonds vertrokken zijbeiden, 's morgens gingen zijbeiden weder landwaarts, de vader kwam wederom, hij zat weer in den tawantop, hij wierp tawanvruchten naar beneden voor zijn kind. Daardoor rook het kind zijn vader, daarom huilde het verbazend, zijn moeder kon hem niet (bedwingen). 's Avonds vertrokken zijbeiden weer, 's morgens gingen zijbeiden weer. Des jongens moeder riep haar jongste zuster, zeggende: kom hier! opdat gij mijn jongen draagt! Toen gingen zij. Serapasamai kwam weer zitten in den tawantop, hij wierp weer vruchten naar beneden voor zijn kind. 't Kind schreide weer, daar hij zijn vader rook, hij zeide: moeder! vader die is hier! Doch de moeder zeide: uws vaders hoofd stak ik in dezen zak. Toen schreide het kind verschrikkelijk erg, zijn tante kon hem niet bedwingen, zij zeide tot haar oudste zuster, zeggende: oudere zuster! dit kind schreit tot ik niet meer kan, dit uw weeskind! De moeder zeide: hij schreit zijn vader zoekende. Toen daalde de vader een weinig af tot hen. Hij brak een tros tawanvruchten af, wierp dien naar zijn kind. En de moeder, dien tros ziende, zeide: die verwenschte vogels! zij vernielen mijns jongens tawanvruchten al te erg! Vervolgens 's avonds gingen zij weder zeewaarts; des 's morgens riep de weduwe haar jongste zuster weer. $\mathrm{Z}_{\mathrm{ij}}$ gingen weer landwaarts, de tante droeg den jongen, de moeder droeg haars mans hoofd. De jongen schreide weder, de tante zeide: dit slechte

1 Een eetbare boomvrucht. 
weeskind schreit te erg! Toen de vader, Serapasamai, hoorde dat de tante 't kind verweet, had hij medelijden met hem, daalde af, brak een tros tawanvruchten, deed die afzakken. Toen zag 't kind op tot hem, en sprak tot zijn moeder, zeggende: vader is daar! Doch de moeder zeide: welneen! uws vaders hoofd nam ik hier mee naar toe, een andere man bedriegt mij hier! Toen daalde de vader af, hij kwam tot zijn vrouw, en zeide tot zijne vrouw: werp weg dat ding! verstop ' $t$ ! ik ben ' $t$ ! Doch zijne vrouw zeide: wel neen! gij beliegt mij! Haar man zeide: 't is niet waar! ik ben het! Toen bracht zijne vrouw het hoofd landwaarts, verstopte het, wierp hare rouwteekenen af. Toen gingen zij zeewaarts. Zijne vrouw ging zeewaarts, en sprak tot hare schoonouders, zeggende: werpt de rouwteekenen weg, uw kind en ik komen hierheen naar buiten. Toen wierpen Serapasamai's moeder en vader hunne rouwteekenen af. Serapasamai's moeder zeide: wel! dat is zooals ik zeide tot $\mathrm{u}$ ! ik zeide: ga landwaarts blijf bij den tawanboom, hij zal uit komen! Toen Serapasamai ging zeewaarts, bleef in 't voorhuis aan de rivier. ${ }^{1}$ 's Nachts (toen) men sliep zeide de man tot zijne vrouw : zoo zij u vragen, zeg niets, blijf slechts hier binnen, antwoord hen niet. Aldus bleef zij in de kamer vier nachten. (dagen). Alle dagen riepen de vrouwen haar om haar te vragen, maar zij kwam niet; zij riepen haar aldoor, maar zij beantwoordde 't niet. Zij riepen haar dagelijks tot zij niet meer kon. Toen ging zij er uit, zij antwoordde de vrouwen in 't achterhuis; Serapasami zat aan 't water haarlieden beloerende. Toen hoorde hij de vrouwen zijne vrouw vragen, zij zeiden: insoppi! als 's nachts uw man bij u slaapt, hoe is zijn lijf ? is het koud? Maar zij antwoordde niet gauw. Zij vroegen haar dạgelijks tot zij 't niet kon (uithouden). $Z_{i j}$ vroeger haar weder: insoppi! 's nachts (als) gij met hem slaapt hoe is hij dan? omdat zijn lijf nieuw is, is 't koud? Toen sprak zijn vrouw, zeggende: wel! koud! Serapasamai (dat) hoorende, (was) beschaamd (en) boos, hij zeide: vrouw! gij! wel! ik onderrichtte je, maar je hoordet niet! Ik zal gaan en ik verlaat uw kind en $u$. En hij nam boog en kleine pijl, en daalde stilletjes van 't voorhuis en vertrok. En zijn vrouw ging naar voren, zij keek zoekende (naar) hem in de beek,

1 Men denke zich het huis gebouwd met de voorzijde, waar de mannen verblijven, in de beek, de achterzijde, waar de vrouwen verblijven, op het land, zoodat de lengte as van 't huis loodrecht op de oeverlijn staat. 
maar zag hem niet, zij zeide: die man daalde af en is vertrokken, hij schaamt zich. Toen nam zij het kind op den rug, zij volgde hem, zij weeklaagde, zeggende (roepende): "echtgenootééê gij? waarheen gaat gij?» Daarom bespiedde haar een oude vrouw, haar naam der oude vrouw is Indokki. $\mathrm{Zij}$ zeide: hé! waarom huil je? wij hier, deden wij je visch vangen bij 't morgen-laag-getij? je visch vangen bij het avond-laag getij? ${ }^{1}$ wij weten daar niet van! wij, deden wij jului heimelijk met elkander praten daar? Hé! wel! neem je zoon, en voed hem met zijns vaders sagopap die hij at, breng den jongen en doe hem eten. Toen gaf de moeder een schelpen armband aan de oude vrouw, zeggende: zeg toch, waarheen ging des jongens vaders? De oude vrouw zeide: daareven ging hij op dezen weg. Toen de moeder (met 't kind) ging, weeklaagde zij weder: «echtgenoot gij! waarheen gaat gij ? echtgenootééé Serapasamai! gij waarheen gaat gij?» Toen schreeuwde Indoki de oude vrouw: hél wij hier, deden wij jelui heimelijk aldus praten met elkander? waarom huil je? breng den jongen hier, hij ete zijn vaders sagopap; hij at de helft opdat gij hem voeren zoudt. Toen gaf de moeder een schelpen armband, een kralen dansschortje, zij betaalde haar, en zeide: zeg den weg aan mij. De oude vrouw zeide: de weg is deze hier, daareven kwam reeds iets hierheen. Toen nam de moeder het kind op den rug, zij gingen; zij (de moeder) huilde weder: "Echtgenoot Serapasamai! waarheen gaat gij? Matonbonbloem! (uw geur wijze mij den weg dien ik gaan moet)». Indokki bespiedde haar weer, zij zeide: waarom huil je? wij, hebben wij je belogen? Huil niet! breng het kind hier, voer het met zijns vaders sagopap, hij at de helft er van. Toen bracht de moeder den jongen, zij voerde hem. Toen gaf zij een schelpen armband (en) een kralen gordel, zij gaf 't aan de oude vrouw, zeggende: zeg me! waarheen ging des jongens vader? De oude vrouw zeide: die, hij ging op dit pad daarheen af. Toen de moeder daalde af, volgende haar man, weeklagende: «Echtgenoot Serapasamai, waarheen ging gij toch? Zij kwam aan Indokki's huis, haar man was ook in dat huis.

1 Indokki bespot met deze woorden de vrouw. Schelp en weekdieren, de gewone vangst der vrouwen zijn 't best te vinden met laagtij na springtij als de koraalriffen droog loopen. En dit is natuurlijk alleen 's middags of middernacht. De bedoeling is dus: wat je overkwam is niet onze, maar je eigen schuld. Wij laten je geen onnut werk doen. 
De oude vrouw riep haar: huil niet! uw man is er! hijzelf zit in dit huis! Toen schreide zij. Zij bleven samen tot 's nachts Serapasamai zeide tot zijne vrouw Imbarasei, hij zeide tot haar, zeggende: van nacht roei ik, ik visch (met een flambouw). Onderhoud 't vuur opdat 't niet uitga, slaapt gij beiden tot ik kom; (als) 't vuur sterft (uitgaat), slaapt jelui maar, ik zal komen met de flambouw, wij steken 't aan, maar gaat gijbeiden niet tot de oude vrouw! Maar de vrouw sliep (en) 't vuur ging uit, en zij was erg koud, zij zag Indokki slapen, en haar beide knieën glinsterden, en de vrouw zeide: daar is vuur! En zij nam een tang, en sloeg de knie af (zooals een kool vuur wordt stuk gestooten om de kool te verdeelen). De oude vrouw schreeuwde (van pijn) zeggende: o wee! mijn knie! neem haar tot je! Je roeit (en) gaat niet meer zeewaarts! gij gaat zeewaarts niet (meer) naar luw vader en moeder beiden! En de vrouw zat tot haar man kwam. Zij sprak tot hem, zeggende: de knieën der oude vrouw heb ik afgeslagen. De man zeide: hè, ik zeide tot je: ga niet tot de oude vrouw daar! maar je luistert niet. Wij zullen niet meer zeewaarts gaan, 't is uit, wij allen blijven in de soeroega. ${ }^{1}$ wij gaan niet meer naar de aarde. Toen zat de vrouw neer, zij schreide vele dagen, zij schreide (beweende) haar vader en moeder beiden. Serapasamai's vader en moeder gingen weder in den rouw om hun kind. De vader en moeder der vrouw rouwden ook allen. Aldus zegt men: die sterven, gaan naar de soeroega, zij komen weder, maar omdat Imbarasei haar man niet gehoorzaamde, sloeg zij Indokki's beide knieën stuk zoo komt het dat het uit is, Indokki verhindert ze; zij (die) sterven zij veranderen niet meer, maar zij verdwijnen (houden hier op te bestaan) in eens naar de soeroega:

A anteekeningen: Vermoedelijk is het plaatsen van een bamboe-buis op het voorhoofd van den doode, als hij in het graf gelegd wordt, zóó, dat het boveneind van de bamboe boven het gesloten graf blijft uitsteken, een in onbruik geraakt animistisch gebruik. De verteller meende dat die buis slechts diende om door dagelijkschen watertoevoer, het ontbindingsproces te bespoedigen. Mij wil het voorkomen dat het doel was: een uitweg te geven aan de in het lichaam nog aanwezige, en door de ontbinding vrijkomende zielestof. Niet onmogelijk durf

1 D. i. het Doodenverblijf. Eigenlijk de hemel, Maleisch sorga. 
ik het te achten dat een op Windèsi nog bestaand gebruik daarmede verband houdt. Men plaatst n. l. op een pas gesloten graf, langs de randen, eenige stokken, die boven het graf tot elkander worden gebracht, op de wijze van boonenstaken. Als de eerste rouw voorbij is, en het spijsverbod opgeheven wordt, gaat een aantal jonge lui naar het graf en werpt met het noodige Papoesche lawaai die stokken om. Die stokken noemt men: aipadewa, en het omwerpen: senbari aipadewa. (bari: omverwerpen).

\section{Bwabwin amori tuter bwabwin manswa.}

Bwabwin amori sièmua aantumbwabwin mònu, bwabwin manswa nie aantumbwabwin siri, sendur na anio siri. Senmasoi to mariapaisi siparaar. Bwabwin manswa tiòpan so bwabwin amori: tunda tunmun pi na maria paraar wasi, ma bwabwin amori tiòpan: wèsjeen! tunda. Ma sunda sunraaš sanu, bwabwin manswa niè mariai, bwabwin amori niè raui. Suntapur kaweě, diaaně, bape bwabwin manswa tipur pau ba, bwabwin amori tipur pau, to niè ròtanpai diònu. Rawiniena sunbabur so sunnè anio, ma suntòpan maso sunraantumbwabwinpaisiat, suntòpan: kausapa menmasoi eja, amunda ja mariapai siparaar abo pimunapaisi pau amunmun esasi ja. Sentena to kausapa, sunda ja. Sunda ja, bwabwin manswa niè mariai, bwabwin amori niè raui. Suntapur to rawiniena, sunbabur eja, bape bwabwin amori sièmua pau, bwabwin manswari niè pau ba, so aikiaipaisi siarieu beja, tipur tindia ba. Sunbabur so aniopai ja, Raria wura sunda tapèna tawana, to raria siri sunda $\mathrm{ja}$, suntapur to, bwabwin manswari bibur papon, kiai mitauni awaab, biata, ma siwara be kapò. Inëni bwabwin amori ria ja, ma sijoor bwabwin manswa, sanepaja ai nini siwara be kapò, ma tiòpan: bwabwin manswa diòtò? rině kapò nèsi ba? Inèni bwabwin amori tituan awaab, dieman rawesipai to kieis, diò dieman rawesipai eja, to betiai aibu, iněni bwabwin manswari diòtar $\mathrm{i}$, diòtar wòtu bwabwin amori aròkòwòrui to biòru. Ma inèni bwabwin manswa kiutu bwabwin amori niè susupai sanu, ma kikutu sanu to menau, kioor sasa monu, sisa sanu, kioor sanu maso bwabwinamori aantumbwabwin sanu, tiòpan: nini diaan, sinjamu dinatu maso manu. Sinjamu diena, pimuna pau beja, sinjamu diëna tuter si, abo siobině si, tiòpan, diòjò: munraan janèsi. Nani kausapa 
ira ja so i. Bape bwabwin amori aantumbwabwinpai sanu sunnunum si to siòtera, sasapai sanu suntòpan: awini susu! awini susu! awini susu! Ma madjawipai tiòpan: babai! sasa siòjò : awini susu! Ma sasapai sanu sunkabio eja: awini susu junum! awini susu junum! Madjawi tiòpan eja: babai! sasanè sunròjò: awini susu junum! Ma inèni sundur sanu mare, sunbaan sanu, sunsajoorririn sinjani susupai sanu, suntòpan: nini awini niè susu! bwabwin manswari miun awini! tapèna kiutu niè susupai sanu, kioor sanu maso tanu, ditawi tanu! Ma sunkabio babera na mitaunsanu: nani tunrone tanè? Ma babai tiòpan: nani tunmun aantumbwabwinpai riwani! Ma kausapa bwabwin manswari tiòpan so siat: munmasoi, abo ira ja so sinjamu. Ma ria to, sunkundur saripai to diòtera. Ma inèni sunsaaw bwabwin manswa aantumbwabwinpai: insòpi! ruaṃa! sujoor awini niě aisasunpaini tiawa mêsu pa! Ma inèni riama ma diutan sanu: tiawa nanè? Ma sunsèwar kamberepai, suntòpan: sueer maji! Inèni sieer maji, sunbubu saripai bera rè, sipipiapar to biòru. $\mathrm{Ma}$ inèni sunda sunkoor niè pimirandinpaisi sunrimirandin $i$, ma sunkoor niè sisěkariesi sunritababaar i, ma sunkoor i a, sunron nanè diòsa na sinjani niè aturèpai, sunda sunkoor mòmò kasi, suntai bibit rèpai, suntai sorèpa tapè miri, ma inèni suntòpan: sinjamu nianari papon so awini, bo! amunron nanari so au pena. Inèni sunnunum pi, sunnunum taunkapajai, sunnunum pau mò to ròtanpai diònu. Inèni sunraniau pisaserapai wura: ai, samuen, rewuki, kamaten, aitiaur, kai, susi, berajaan, aidiaru, ajuki, roit, kakibari, dui, surawa, nandau, ampeer, kapa, koir, kěrakěrai, ingrèsi, pi borei wura to simasis. Sunparo aisasunpai. Inèni sunbabur.

Inèni rawiniëna manswapai riama, sijoor aantumbwabwinpai mirandin, diòsa na sunnè aturèpai, saněpaja tienam, tiòpan: buòtò? bepisabirě? api munrandin pa? tandoi so au to nè? tantajaan tandoi so au to nè? api munrandin pa? Tiòpan: muniniawar tòrò! Inèni sinjani riama siaji tiawipidiaar $\mathrm{i}$, diòtò : buòsa berusua, irama tu. Ma siuapui, misoi, niunum pi, disin anam, riaan diaan, kawe, to simasa, ma inèni siaaw aantumbwabwinpai, diòtò: insòpi! ruama! inèni buaan pi! Bape riama ba, siaaw to mirioor, tiòpan: ruama ba penai? jaan inèsi pěnai? mèmu si è inè si ma jaan si sarĕdjeu, nani, bwabwin au bo! nani nunum esasi, buaan si! Sinjani diaan pi to menau, aantumbwabwinpai riama ba, kioor winioipaisi apui, diò rioram si, rioram si to 
měnau, inèni kioor si apon. Ma inèni siaaw aantumbwabwinpai ja, bape didjawa ba, sinjani diò ria kioor i. Ma ria riut i na aantumbwabwinpai warapaisanu, riut $i$, ma pia ba, aantumbwabwin misasop awaab. Ma inèni sinjani sijoorririn i biòru, niajaan bwabwin amori aantumbwabwinpaisanu, dipariori: mamberobi! sunmun i! Ma inèni ria diutan pisaserapaisi, bape sentòpan sanu ba, to aisasunpai tiòpan sanu, tiòpan: sunbabur na jana!

$\mathrm{Ma}$ inèni diusar sanu to diru, sunrena na aiwaarpai rawesi, bwabwin manswari diëna na rawesi. Ma deriasi sasaar bwabwin manswari sisin: bu! ba! Ma bwabwin amori aantumbwabwinpaisanu, madjawi tiòpan: babai! pi bemun awinipai ni, sisin pa, diòjò: bu! ba! Babai tiòpan: awini ninò? mèmu taunkapajai pi nina! buon nanè sasaar na amun, ma diru na bwabwin manswa, nia. Ma sasaar papon na bwabwinamori aantumbwabwinpaisanu, sunbabur to wòroi, inèni sasaar na bwabwin manswa nia. Inèni diòsa, tiawarira airumwajapai, ma sijoor sunnè kairpai, tiòpan: mamberobi! itawarira besiri ma rêto! imun sanu! Diusar sanu ja to diru, bwabwin amori aantumbwabwinpaisanu sunrena na aiwaarpai rawesi, bwabwin manswari diena rawesi, inèni sentena. Deriasi sasaar sunradjawa bwabwin manswa sisin eja: bu! ba! Madjawi tiòpan: babai! pi bemun awini sisin eja: bu! ba! Babai diòtò: awini ninò! mèmu taunkapajai buon nanè sasaar na amun, ma diru na bwabwin manswa nia! Ma sasaar na sanu, sunbabur to woroi sasaar na bwabwin manswa, diòsa, tiawarira, sioor eja sunnè kairpai, tiòpan: itawarira besiri ma rèto, isěmuai sanu. Rariapaisi wura diusar sanu tawana, to sendama so maria babapai, sunsajoor diaankariria diboi na kambupai, sunsaaw i, sunròtò: apusi! ruama! kuoor nanu abaru so rawesi wa! Ma diaankariria tiòpan: ama munda munkoor airamuan be matu ma mundur i ma munkoor jau mare, munsobin jau! Inèni sunkoor $\mathrm{i}$ are, sunpir $\mathrm{i}$ so roitpai, inèni sunsobin $\mathrm{i}$ to sininiaja. Ma inèni sunkoor $\mathrm{i}$ arau, suntabaat $\mathrm{i}$ biata raropai. Inèni sunbera na $\mathrm{i}$ abaru, ma diaankariria tiòpan: mundawain sanèkwai, muntara na $\mathrm{i}$ penai! Inèni sundabaru so rawesi $\mathrm{pa}$, inèni sunròsar sunraniwar mantaunsanu, sunraduaat bwabwin manswapai. Inèni bwabwin manswa riama, ma titaar ria ta. Inèni sijoor diaankaririapai diboi, siaaw i: apusi! sanÆpai jau! kuoor jau mabaru! Diaankariria tiòpan: kuoor airamuanpèsasi buisobin jau papon! Inèni kioor i mare, siobin $i$, bape kioor airamuan bematu ba, kioor aikamaru, disobin $i$, tapèna sininiaja tindia ba. Inèni pir 
i tu abaru, inèni bwabwin manswa biëra biërabaru to betiai rabwan, diaankariria dio mirutu katu. Ma bwabwin manswa tiòpan: apusi buawi jau pe? Ma diaankariria tiòpan: jawiau ba, katuena apusisanu sunbera pa tapèna. Ma ria katu mirutu eja to bietiai na bwabwin manswa sanèkwaipai, ma diutan $i$, diòjò ja: apusi! buawi jau pe? Ma inèni bwabwin manswa tiaar katu $\mathrm{ja}$, inèni tiaar na diaankariria sanèkwaipai. Inèni diaankaririapai riobai mitauni, bwabwin manswa tiawa, mirutu, diaankaririapai kioor diaan i. Inèni bwabwin arapai sanu sunsubi marau, sunmaji kainam so $i$, sunròtò: berère! buon papon so awini pena! inèni amunron beruwani so au!

Inèni měnau sunbabur sunda to sunsèmuai katimpai mònu, sunsaji sunraan tawan, sunraniau sunnè ròtanpai sanu, sunròtò: munsjawa to esi riama munsjoori. Ma inèni bwabwinkatupai sanu sundama, sunsèmuai ròtanpai sanu, apapè ròtanpai sanu sunsjoori. Ma inèni katimpai esipai dimis esipai: buaar awaab, sujoor tatoa, ròtanpai sanu sunsioori bo! esi riama pe? Ma ria arawaab sijoor bwabwinkatu sanu, siaaw esipai, diòtò: tuòpi! buaar mèsu! Ma biaar awaab sunsajoor bwabwinkatupai sanu. Bwabwin amori aantumbwabwinpai sanu, babai sanemkariria katimpai sanu, tiòpan riaut sanu wura, tapèna diawi madjawi, tiòpan: insòpi! rua, kuoorè awini niè ramoortawapaisi, tunbaburè si to na rawesipai, tunsobin diaankaririapai napa. Ma inèni madjawi ria, babai kioor katimpai sanu senbabur. Madjawa siobera ma sisěrei siat, sieis: babaiè! miat menda toi nè? Bape siri riaar so $\mathrm{i}$ ba, ma ria sieis to, siaaw sasera siat: miat! menda toi nè? Bape sendaar ba so $i$, senda papon, senkaròtu aipaisi, senpir i biabedjoor raan senda na paï. Ma inèni madjawi ria sijoor tawaipai niè raanpai kikabi, saněpaja: babai raan senda napai nina. Bape ria katu sijoor tawaipai niè ròmipai, sijoor aji, sijoor: sèberianipai mirai tòrò, siaji piòtu esasi, kioor si mèsu, diò misoi diaan si. Ma sijoor apui so aipai wabapai tawaipai diajaas $i$, biata na aipai wabarpai. Sijoor i, mitait i, diò tibasa bibur, tawaipai riëra mitauni, kiai bedjoor $i$; diò tibera so esaja, tawaipai kiai bedjoor i ja. Inèni bwabwinkatupai sieis tòrò, sieis sasera babai, siat senbabur so wiarieu, esi didjawa $\mathrm{i}$ ba. Inèni tibera riausaar tawaipai niè raanpai. Sunda rau, sijoor tawaipai niè aniopai, tawaipai ria pipon i. Inèni tawaipai dipu rupai na atèpai, saněpaja bwabwinkatu nini siaji na i. Inèni siaji so aniopai, bape minasin ba, sieis tawana. Bape 
tawaipai ria dipu rupai na nando rumwaja, tobu rumwaja, pi ròmi bepau wura: warimuè, sèberianiè, raunè, pi ròmi jani wura. Inèni bwabwinpai rina, diòtò: sa! ira ikoor si, jaan si! $\mathrm{Ma}$ ria kioor $\mathrm{si}$, diaan si, ma inèni sunmasoi to dion ririn tawaipai. Inèni sunrena to, dirurabwan biesinjontu, rawatawaipai biata, deriasi sasaar siuwa apui so niè rawatawaipai. Tapèna to bwabwinpai sanèbaba to. Inèni diawin marariapai, Sinjani diò ria kioor pi ròmi, mamò tamaani biata tuter aantum, didjawa sinjani riama bibura, biaat wesje. Raria wura tapèna: sinjani diò ria, tamaani biata tuter aantum; to biba, siaaw apai tuter atobini. Bape sinjani tiòpan: tanè? ipa ba inanari nini so au! tamamu kòta pia ba! Ma raria siri sinjani sunmasoi, tamaani ria niunum riwani mitauni rawatawaipai, rawatawaipai riwani be: sisè, serakè, sampaarè, raarè bepau jani wura. Inèni bibur maso aniopai, siajis, ria pon, misoi asisi na reponpai. Bape bwinieempi rin i ba, aantumpai diòjò siubi rari, sijoor apon, sijoor tamaani, sieis: awini! jò ira so jai! Sinjani tiòpan: tamamu ! na? Bape tiòpan: pibai, jò! ira so jai! Ma inèni sinjani siubi ari, sijoor apon, sijoor tamaani, ma inèni dimis aantumpai, tiòpan: watan! rua pon so tamamui! Ma ria pon, sieis apai, tiòpan: jai! sanèwèsjeen apai, atobini! Ma tamaani tiòpan wenasja: apai, atobini sibemawas! Ma aantumpai riut si. Ma inèni dimis bwinieempi, diòtò: rua re! sujoortawan rawapai. Ma ria re, sijoor pi saserapai sibata mirarojar. Ma inèni ria dirien si to aniopai kiòtar. Inèni diò sendoi, ma ria siserei beaandoi, ma ria sièmuai aniosepèsi. Inèni siaaw siat, tiòpan: mendama, tandoi! Ma kawàsa borei senda, to babai sawani senda kòta. Babai diawin beja, sièmuai marariasiat pau beja, kietè esi, biai esi, kibuba esi, bebabapaisiat senda. Sendama to, senmaji to kausapa, to senda senkoor kambu. Inèni babai sijoorririn $i$, diutan i: insòpi! au na nè? Madjawi tiòpan: jo! jana! Ma inèni senda rau so aniopai, ma sendoi to mennau, sentò senbabur. Bape babai kimberei ria, diò saněpai madjawipai, tiòpan misoi tuter i. Bape diawija, diòjò: madjawi sundaut $\mathrm{i}$ wura. Bape madjawi miajar ba, tiòpan: tundaut $\mathrm{i}$ wura so? Saněpaja sinjontu watan nina te? Tawai nina! Bape bubur jau! Ira isaserei au tuter katim mònu, ma ira to isèmuai tawai nini, iraut $i$. Tanè sanemkariria i, buòjò : tundaut i wura? Imajar i ba! Bubur saredjeu! Tapèna mimaja, bibur. Inèni senbabur wura. Inèni měnau, sawani sunmasoi, sunmèser $i$, sunmasoi. 


\section{Vertaling :}

De wijfjes kangoeroe en de wijfjes kasuaris.

De wijfjes kangoeroe kreeg twee dochtertjes, de wijfjes kasuaris had een dochtertje. Zij waren bijeen in één huis. Zij bleven tot de beken droog waren (weinig water hadden). De wijfjes kasuaris zeide tot de wijfjes kangoeroe: laten wij beiden visch gaan vangen in de drooge beek daar, en de wijfjes kangoeroe zeide: goed, wij gaan. $\mathrm{Zij}$ gingen ieder huns weegs, de kasuaris had de monding, de kangoeroe den bovenloop. $\mathrm{Zij}$ vingen garnalen en visch, maar de kasuaris ving niet veel; de kangoeroe ving veel, tot haar zak vol (was). 's Avonds vertrokken zij naar haar huis, en zij spraken tot haar beider dochtertjes, zeggende: morgenochtend blijft jelui weer, wij gaan weer naar de drooge beken, omdat (daar) veel beesten (zijn). Wij vangen weder eenige. $\mathrm{Zij}$ sliepen tot den morgen, en zij beiden gingen weder. $\mathrm{Zij}$ vingen tot 's avonds en zij vertrokken weder, maar de kangoeroe kreeg veel, de kasuaris had niet veel, want haar teenen waren te lang, zij ving niet goed. $\mathrm{Zij}$ beiden vertrokken weder naar huis. Alle dagen gingen zij beiden aldus, dagelijks, tot op een dag zij beiden weder gingen, en vingen, de kasuaris vooruit liep, zij wierp zich neer, zij lag, en zij werd begroeid met truffels (champignons). Daarna ging de kangoeroe weder, en zij zag de kasuaris; denkende: dat is hout, begroeid met truffels, zeide zij: wat scheelt de kasuaris? kent zij deze truffels niet? Toen bukte de kangoeroe neer, plukte één zijde tot 't op was; zij wilde de andere zijde plukken; toen zij plukte die kleefden (vasthechten) (aan de) knie, schopte de kasuaris haar, zij schopte der kangoeroe hartkuil stuk, dat deze stierf. ${ }^{1}$ En daarna sneed de kasuaris de kangoeroe de beide borsten af, en sneed die beide in kleine stukjes tot het klaar was. $\mathrm{Zij}$ nam twee bamboes, zij stopte ze er mede vol, bracht ze aan de beide dochtertjes van de kangoeroe, zeggende: dit is visch, uw moeder zendt 't $u$ beiden. Uw moeder slaapt (daar), (er zijn) te veel beesten, uw moeder slaapt er bij, opdat zij ze roostere. $\mathrm{Zij}$ sprak zeggende: eet gij beiden deze.

1 De linker en rechter binnenteen van de kasuaris dient als stoot-wapen dat zij op dezelfde wijs gebruikt als een haan zijn spoor. Dat een kasuaris een mensch kan dooden, moet geen sprookje zijn. Honden vallen dikwijls als slachtoffers der kasuarissen.

Dl. 70. 
Morgenochtend zal ik weder tot haar gaan. Maar (toen) de dochtertjes der kangoeroe beiden ze kookten tot het gaar was, zeiden de beide bamboes: moeders borst! moeders borst! moeders borst! moeders borst! En de jongste zuster zeide: oudere zuster! de bamboes zeggen: moeders borst! En de bamboes zeide weder: ik drink aan moeders borst! ik drink aan moeders porst! De jongste zeide weder: oudste! deze bamboes zeggen: ik drink aan moeders borst! En toen namen zij ze beiden mee naar achter, zij kloofden ze, (en) herkenden de borsten harer moeder. Zij zeiden: dit zijn moeders borsten! de kasuaris doodde moeder, aldus haar beide borsten sneed zij af, ze bracht ze aan ons, ons beliegende! En zij bespraken met elkander: wat zullen wij doen? en de oudste zeide: wij zullen haar dochtertje dooden in ruil (voor onze moeder). En 's morgens zeide de kasuaris tot haar: gij beiden blijft, opdat ik weder tot uwe moeder ga. En toen zij gegaan was, kookten zij beiden (in een bamboe in 't vuur gelegd) sari-olie tot zij kookte. En toen riepen zij het dochtertje van de kasuaris: insòpi! kom hier! zie moeders (houten) vlechtnaald is naar beneden gevallen! En toen kwam zij en vroeg haar beiden: waar viel die? En zij beiden maakten een opening (in den vloer der paalwoning), zij zeiden : zie naar boven! Zij stortten de olie op haar oogen, en zij spartelde tot zij stierf. En toen gingen zij beiden, zij haalden hare danssieraden, zij versierden haar daarmede, en zij haalden haar versierden schaamte-gordel, deden haar dien aan, zij brachten haar weg, zij deden haar daar staan in de deuropening haars moeders, zij gingen valsche-broodvruchtboom-sap halen, (daarmede) kleefden zij de oogen open, zij kleefden de mond alsof zij lachte, en toen zeiden zij: uw moeder deed ('t) eerst aan onze moeder, ' $t$ is wel! wij beiden doen het nu aan $u$ ! Toen bakten zij eten, zij bakten ronde sagokoeken, zij bakten zeer veel tot de zak vol was. Vervolgens onderrichtten zij alle dingen (om haar niet te verraden): 't hout, 't gras, de steenen, de vuurhaard, de houten haardbak, de sagostokjes, de zeef voor natte sago, de zeef, de roerspaan, het droogrek, de vuurtang, de nibong-vloerlatten, de boomschorswand, de dakbedekking, de sagoblad-stelen (waarvan de buiten-wand des huizes wordt gemaakt), de hagedissen, de wandluizen, de spinnen, de kakkerlakken, vele dingen allen tot 't genoeg was. $\mathrm{Zij}$ vergaten de houten vlechtnaald (te onderrichten). Toen vertrokken zij. 
Toen des avonds de kasuaris kwam, zag zij haar dochter versierd, staande in haar deuropening; denkende zij leeft, zeide zij: wat moet ge? ben je gek? waarom heb je je versierd? zingen wij hier al voor jou? Zijn we samen om voor je te zingen hier? Waarvoor heb je je versierd? $\mathrm{Zij}$ zeide: je zoekt erg je te doen bewonderen (of: de aandacht te trekken). Vervolgens kwam de moeder naar boven, haar op zij stootende, zeggende: ga op zij staan, dat ik voorbij kan gaan! En zij ging naar binnen, zat neer, makkte eten klaar, bereidde sagopap, kookte visch en garnalen, tot zij gaar waren, en toen riep zij haar dochter, zeggende: insòpi! kom hier, eet dan! Maar zij kwam niet; zij riep tot zij moede was; zij zeīde: weiger je te komen? wil je niet (dat) ik 't mijne eet? het uwe heb ik hier, ik zal 't maar opeten' wat zou 't ? gij (zijt een) vrouw, welnu gij kookt ander eten, gij eet dat! De moeder at tot zij klaar was, de dochter kwam niet. $\mathrm{Zij}$ bracht de etensbakken naar achter, willende die wasschen. $\mathrm{Zij}$ wiesch ze tot 't klaar was, toen bracht zij ze weer naar voren. En toen riep zij haar dochter weer, maar deze hoorde niet; de moeder wilde haar gaan halen. Maar zij ging, vatte beide handen harer dochter aan, hield haar vast, maar zij kon niet, het meisje viel slap neer. En toen begreep de moeder dat zij dood was, zij schold op de dochtertjes der kangoeroe. Zij schreeuwde: mamberobi!! zij doodden haar! En toen ging zij alle dingen ondervragen, maar die noemden die twee niet, tot eindelijk de vlechtnaald haar noemde; die zeide: zij zijn weggegaan, daarheen!

En toen vervolgde $z i j$ die beiden tot den nacht. $\mathrm{Zij}$ beiden sliepen tusschen de boomwortels aan de eene zijde van een boom, de kasuaris sliep aan de andere zijde. ${ }^{1}$ En toen het bijna licht werd flatuleerde de kasuaris: bu! ba! En van de de beide dochtertjes der kangoeroe, zeide de jongste: oudste! die onze moeder doodde (is) hier, zij flatuleerde, zeggende: bu! ba! De oudste zeide : moeder (zijt) gij hier? hier is uw ronde sagokoek, geef daarvoor licht aan ons beiden, en nacht aan de kasuaris hier! En ('t werd) éérst licht voor de kangoeroedochtertjes. Toen zij ver gegaan waren (lett. zij vertrokken tot ver), toen lichtte het voor de kasuaris. Toen stond zij op, ging rondom den boomstam, en zag haar-beider nachtleger, (n.l. de

1 Bij de hevige regens in deze streken ( $14000 \mathrm{~m}$. M. per jaar) liggen de groote wortels der boomen, door het wegregenen der aarde, boven op den grond. 
indrukken ter plaatse waar zij gelegen hadden) zij zeide : mamberobi! ware ik maar ineens rondgeloopen, ik had ze gedood! Zij vervolgde ze weder tot den nacht, de kangoeroe's dochtertjes sliepen tusschen de boomwortels ter eener, de kasuaris sliep ter andere zijde, toen sliepen zij. Nabij den dageraad hoorden beiden de kasuaris weder flatuleeren: bu! ba! De jongste zeide: oudste! die onze moeder vermoordde flatuleert weer: bu! ba! De grootste zeide: moeder zijt gij hier? geef voor uw ronde sagokoek licht aan onsbeiden, en nacht aan de kasuaris! En 't lichtte voor haarbeiden, toen zij ver weg waren lichtte het voor de kasuaris, die opstond, rondliep, haarbeider leger zag, zeggende: had ik maar ineens rondgeloopen, ik had ze gekregen! Vele dagen vervolgde zij die beiden dagelijks tot zij kwamen aan een rivier. Zijbeiden zagen een krokodil drijven op het water, zij riepen hem, zeggende: grootvader! kom hier! breng ons over naar dien kant! En de krokodil zeide: gaat dan en haalt brandhout hierheen, en maakt vuur, en haalt mij op 't land, en droogt mij. Toen haalden zij hem op 't land, (op den oever) legden hem op het rookrek (droogrek), toen droogden zij hem tot hij droog was. En toen brachten zij hem naar buiten, zij (legden) hem dwars over de beek. Toen gingen zij over hem heen, en de krokodil zeide: stap over mijn navel, trap er niet op! Toen gingen zij over naar de andere zijde, vervolgens verstopten zij zich, en loerden op de kasuaris. Toen kwam de kasuaris, en wist niet hoe te gaan. Toen zag zij den krokodil drijven, zij riep hem: grootvader! heb mij lief! breng mij over! De krokodil zeide: breng brandhout, droog mij eerst. Toen haalde zij hem op den oever, droogde hem, maar zij bracht geen hard hout, zij bracht jong hout, zij droogde hem, aldus (werd) hij niet recht droog. Toen legde zij hem over de beek; vervolgens liep de kasuaris er over tot zij op 't midden vastkleefde; de krokodil begon een weinig te zinken. En de kasuaris zeide: grootvader, belieg je me? En de krokodil zeide: ik belieg je niet, daareven gingen reeds twee kleinkinderen aldus. En zij ging een weinig toen zonk hij weer tot het kleefde ('t water kwam) tot aan den navel der kasuaris, en zij vroeg weder, zeggende: grootvader, bedriegt gij me? En toen stapte de kasuaris weder een beetje, toen trapte zij op des krokodils navel. Toen draaide de krokodil zich onderstboven, de kasuaris viel, zonk, de krokodil nam haar en at haar. Toen kwamen die beiden uit naar buiten, zij krabden 
afval over haar, zeggende: lekker! gij deedt eerst zoo aan moeder, vervolgens doen wijbeiden zoo in ruil aan jou!

Toen dat klaar was, vertrokken zij, gaande tot zij kwamen bij twee jongelingen, die (in een tawanboom) geklommen waren om tawan te eten. $\mathrm{Z}_{\mathrm{ij}}$ hadden hunne zakken onderricht, zeggende: gijbeiden hangt tot er iemand komt (dan) fluit gijbeiden (z. a. men op de vingers fluit). En toen kwamen de beide meisjes, zij vonden de beide zakken, en toen floten de beide zakken. En toen zond de eene jongeling den ander: daal naar beneden, zie toe, de beide zakken floten, komt er iemand? En hij ging naar beneden, hij zag de beide meisjes, hij riep den andere zeggende: tuòpi, kom af tot mij! En hij daalde af, zijbeiden zagen de beide meisjes, de beide kangoeroedochtertjes. De groote begeerde de beide jongelingen, zij wilde ze beiden huwen, daarom beloog zij de jongste, zeggende: insòpi! ga! haal moeders oude kralen, wij verlieten ze (lieten ze liggen) aan dien kant waar wij den krokodil droogden, daar! En toen de jongste ging, nam de oudste de beide jongelingen, zij gingen weg. De jongste terugkeerende, zocht hen, zij huilde: oudste! waarheen zijt jelui gegaan? Maar niet één antwoordde haar, en zij ging al huilende; roepende zocht zij hen: gijlieden! waar gingt gij heen? Maar zij antwoordden haar niet, zij gingen vooruit, zij braken houten af, zij legden die het pad versperrende waar zij liepen. En toen de jongste ging, zag zij het effen pad van een slang, denkende: het pad waar de oudste is gegaan, is dit. Maar een weinig verder gaande zag zij den tuin der slang; zij zag naar boven, zag zeer rijpe papaja's, zij klom naar boven en plukte eenige, nam ze mee, willende gaan zitten om ze te eten. En zij zag onder den boom, een slang had zich eromheen gewonden, zij lag onder den boom. Zij zag haar, vreesde haar, wilde opspringen en weggaan; de slang wikkelde zich af, en wierp zich (voor haar om) haar tegen te houden; zij wilde zich elders heen wenden, de slang wierp zich weder (voor haar om) haar te verhinderen. Toen huilde het meisje erg, zij huilde om haar oudste zuster, (maar) zij waren ver weg, niemand hoorde haar. Toen keerde zij om, zij volgde den weg der slang. Zijbeiden gingen af, zij zag het huis der slang; de slang ging voor haar uit. Toen tikte de slang (met) den kop op de trap, denkende het meisje er langs op (te laten) stijgen. Toen klom zij in 't huis, maar zij hield niet op met huilen, zij huilde dagelijks. Maar de slang 
ging en tikte (met) haar kop tegen een pisangstam, suikerrietstam, (tegen) alles wat in den tuin was: keladi, papaja, bladgroenten, deze tuingewassen allen. Toen werd de vrouw lief (tevreden), zeggende: wel aan! ik ga ik haal ze, ik eet ze! En zij ging ze halen, zij at ze, en toen bleven zijbeiden tot zij gewoon was aan de slang. Toen sliepen zij samen, te middernacht werd hij mensch, de slangenhuid legde hij af; tegen dat 't dag werd ging hij uit naar voren naar zijn slangenhuid. Dat zoo zijnde werd de vrouw zwanger. Vervolgens baarde zij een zoon. De moeder wilde tuinvruchten gaan halen, waarom de vader bij het kind lag; (als) hij de moeder hoorde komen, ging hij weg en lag elders. Alle dagen ging dat zoo: de moeder wilde gaan, de vader lag bij het kind, tot het groot (was). Het vroeg om een boog en kleine pijltjes. Maar zijn moeder zeide: hoe kan dat? ik kan dat niet voor je maken, uw vader kan 't ook niet! En op zekeren dag bleef de moeder met het kind; de vader ging, verbrandde in ruil zijn eigen slangenhuid, de slangenhuid veranderde in katoen, zilveren armbanden, schelpen armbanden, alzoo in vele goederen. Toen vertrok hij naar huis, steeg op, ging naar voren, zat stil neder in 't voorhuis, maar zijne vrouw wist het niet. Het kind wilde naar buiten (de kamer), hij zag naar voren, zag zijn vader, huilde: moeder! ik wil naar vader gaan! De moeder zeide: waar is je vader? Maar hij zeide niets; (anders dan) ik wil naar vader! En toen de moeder uit (de kamer) kwam zag zij naar voren, zag den vader, en toen zond zij het kind, zeggende: waarlijk! ga naar voren naar je vader! En hij ging naar voren, hij huilde om een boog, en zeide: vader! ik wil een boog en pijltjes! En de vader zeide slechts: boog en pijl, dat is gemakkelijk! En het kind hield ze (in de hand). En toen zond hij zijne vrouw, zeggende: ga landwaarts! zie goed uit (naar) de (slangen)huid. En zij ging landwaarts, zij zag: daar lag allerlei in menigte. En toen ging zij het overbrengen, tot 't huis overvol was. Toen wilde zij zingen (feest houden), en zij ging eten zoeken voor 't feest, en zij gaande vond een negri. Toen vroeg zij hen, zeggende: komen jelui? wij zingen! En vele menschen kwamen, tot haar oudste zuster en echtgenoot gingen ook. De oudste had erg veel gebaard, zij had zeer veel jongens gekregen, een droeg ze voor 't lijf, een op den rug, een op den nek, de grooten liepen. Toen zij gekomen waren dansten zij tot den morgen, totdat zij water 
gingen halen. Toen herkende de oudste zuster haar(en zeide): insòpi! ben jij daar? De jongste zeide: ja! ik ben het! En toen gingen zij naar het huis, en zij zongen tot het klaar was, zij wilden vertrekken. Maar de oudste wilde niet gaan, zij zeide dat zij haar jongste zuster lief had, zij zeide: zij bleef met haar. Maar zij loog, zij wilde hem huwen, zij en haar zuster (de man van de jongste n. 1.) Maar de jongste wilde niet, zij zeide: waarom zouden wij hem samen huwen? Denk je (soms) dat dit een echte man is? 't Is een slang! Maar verlaat mij! Ik ging ik zocht je met de twee jongelingen, maar ik liep tot ik deze slang vond, ik trouwde hem. Waarom begeer je hem, willende dat wij hem samen huwen? Ik wil dat niet! Ga maar weg! Aldus zich schamende (beschaamd gemaakt) ging zij weg. Toen vertrokken zij allen. Toen dat uit was bleven de man en zij samen, zijbeiden alleen, zij bleven. 